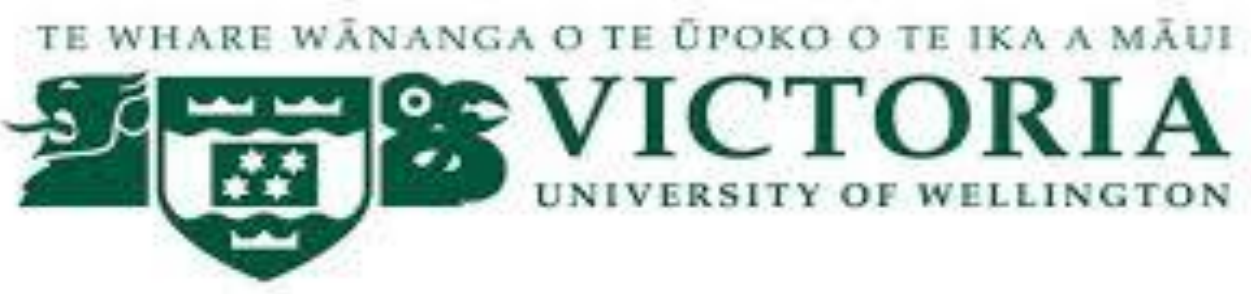

School of Geography, Environment, and Earth Sciences Victoria University of Wellington

New Zealand

Exploring the Impact of Resettlement on Women: A Case Study of the Nam Mang 3 Hydropower Dam in Central Laos

\title{
Singkham Lueyeevang
}

A thesis submitted to Victoria University of Wellington in partial fulfilment of requirements for the degree of Master of Development Studies 



\section{Abstract}

Over the last decade, construction of hydropower dams has increased rapidly around the world, including in developing countries. For many countries including Laos, energy production and export play a significant role in promoting and boosting economic growth and development. Energy production generates substantial revenue and foreign exchange from exporting electricity and expands economic activity domestically. However, construction of hydropower dams also causes negative effects on the people who live at and around the dam site. Some local communities have been affected indirectly, while others require relocation to other areas bringing significant change, including for women.

This research explores the impact of resettlement from hydropower dam creation on women by using the Nam Mang 3 hydropower dam in central Laos as a case study. This dam, completed in 2005, required the relocation of approximately 150 households from two villages at the dam site. The research draws on a social constructivist epistemology, qualitative methods including semi-structured interviews, and analysis of relevant policy documents. Interviews involved 18 participants including both male and female from the three affected villages.

Results indicate that the resettlement of villagers by the Nam Mang 3 hydropower dam has generally improved living conditions of the resettled communities. Women were found to have greater opportunities to benefit from home-based business, employment and wage labouring. In addition, with better access to modern facilities and services, women have been able to save greater time from agricultural activities and divert this time saving to other economic activities. Overall, access to water supplies, roads, and transport have reduced women's workload significantly. Access to improved health services and facilities have also improved women's wellbeing. Girls have greater opportunities to attend school and seek employment in towns. However, this research identified some challenges experienced by the resettled such as the reduction of agricultural and grazing land area, and that new livelihood options were not accessible to all women. Instead of these challenges, the experience with the Nam Mang 3 hydropower project has highlighted one of the key lessons learnt that is worth 
highlighting for future resettlement programs, which is to have the resettlers fully engaged in the entire process of resettlement and livelihood strategy development. 


\section{Acknowledgements}

In recognition of the support and assistance throughout this research, I would like to acknowledge the contribution of a number of people, individuals and groups who have enabled me to successfully complete this thesis.

First of all, I would like to thank all my research participants from Phoukhoakeo, Phoukhaokhouay, and Vangheu villages in Laos for their warmth, interest and sincerity to make my fieldwork such an inspiring and invaluable experience. Many thanks also to the chiefs of the three villages for facilitating and supporting the fieldwork, so it could be carried out smoothly.

I would also like to extend my profound gratitude to the Electricite Du Laos (EDL) and the Nam Mang 3 office. I am deeply grateful for their permission for this research to be conducted in the project affected villages, providing me with information regarding the resettlement programs, and offering me the most valuable support and advice during my fieldwork. I am also thankful to my research assistant who kept me company throughout the research fieldwork and gave me a great deal of support with facilitating the interviewing process. Also, a special thanks to the Nam Mang 3 office staff who helped coordinate the fieldwork.

I am also indebted to my supervisors, Professor John Overton and Dr Luke Kiddle who have provided enormous academic support for me throughout the entire research process. Their professional assistance and consistent guidance were critical to make this thesis possible. Their constructive comments and feedback during the writing process added great value by making this paper more critically sound. A sincere appreciation also goes to my other lecturers at the School of Geography, Environment and Earth Sciences (SGEES) for the notable assistance through sharing of their knowledge over my two years at Victoria University of Wellington (VUW).

I wish to also express my sincere appreciation to New Zealand Aid (NZAID) who granted me the opportunity to undertake my postgraduate studies in New Zealand. Without this financial support my study and research would not have been possible. Special thanks also go to the Victoria International Office team for your excellent support and service 
over the period of my study at VUW. Further thanks to Student Learning Support staff for helping me improve my language and academic writing. The learning support both before and during my thesis writing have been very much appreciated.

I will not forget the friendship, encouragement, and support from my fellow classmates and friends at Victoria University of Wellington over the last two years. They have been meaningful and filled with many beautiful memories.

Finally, heartfelt gratitude and appreciation go to my dearest parents (Khouakoua Vang and Der Thao) and my sisters for their consistent encouragement and unconditional support over the past years of my education and academic journey. Last but not the least, to my wonderful wife, Pachouaxong, and son, Larlee, for their understanding and patience during my absence from home, and particularly for their inspiration, love and enduring moral support. 


\section{Table of Contents}

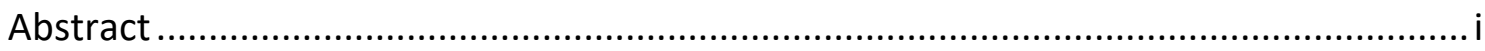

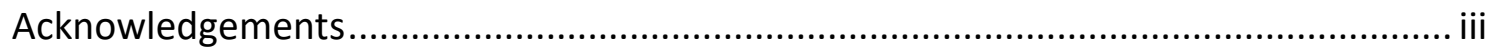

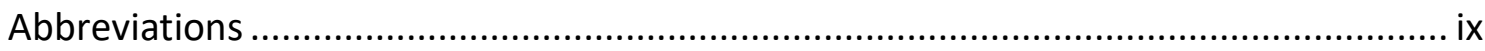

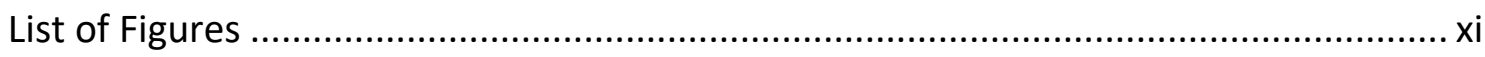

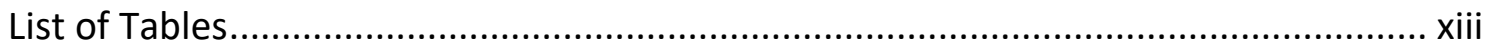

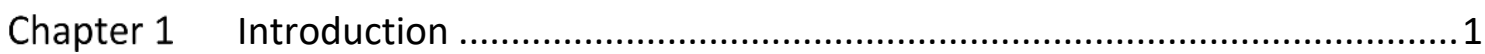

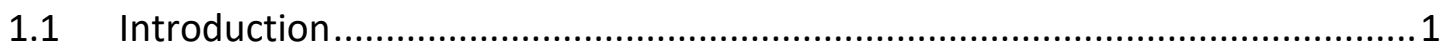

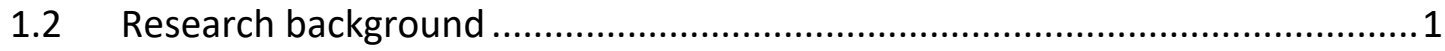

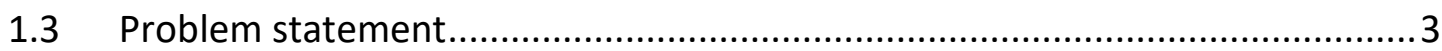

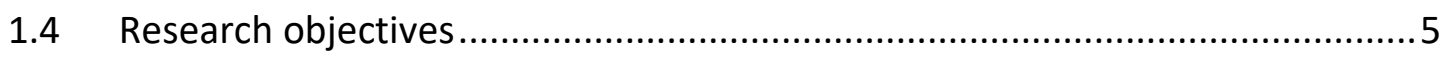

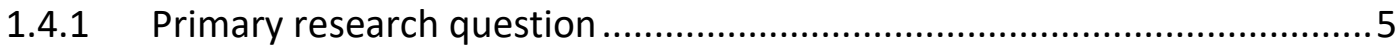

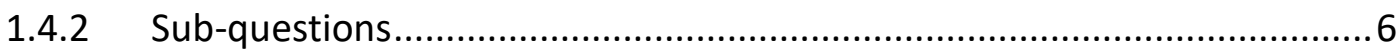

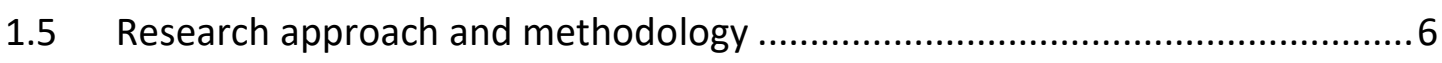

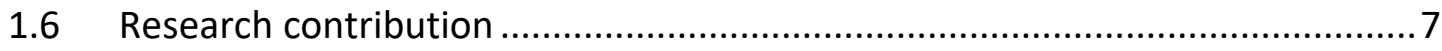

$1.7 \quad$ Thesis outline

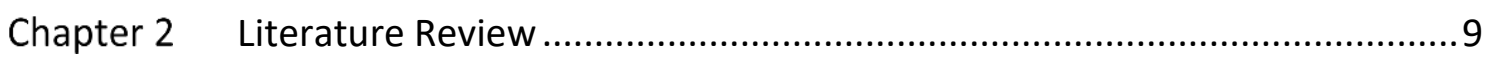

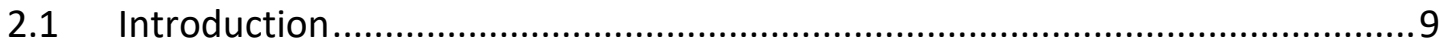

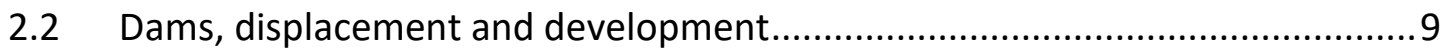

2.3 Gender, development and displacement................................................... 10

2.4 Resettlement and its impacts on women ................................................11

2.5 Compensation, rehabilitation and the impacts on women ............................15

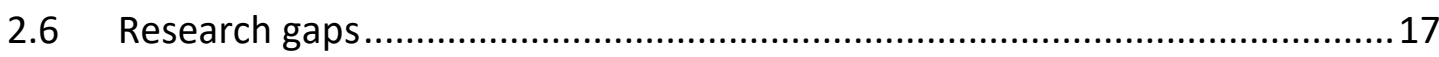

Chapter 3 Laos, Hydropower, and Women's Development in Laos..........................19

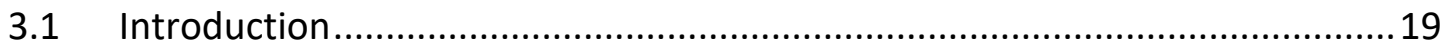

3.2 Geography, population, and socio-economic characteristics .......................19

3.3 Hydropower and socio-economic development policy .................................23

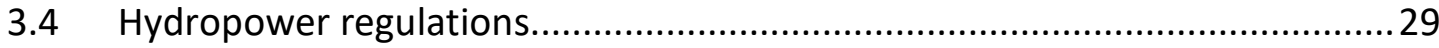

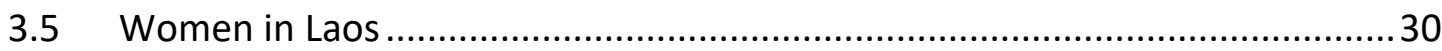

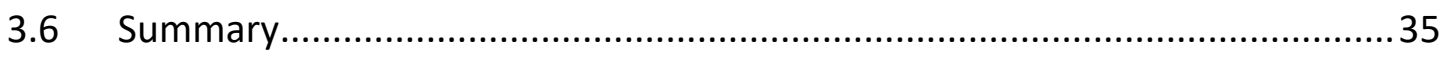

Chapter 4 Epistemology, Theoretical Framework and Research Methods ...............37

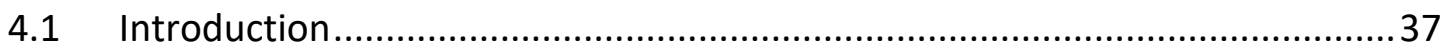




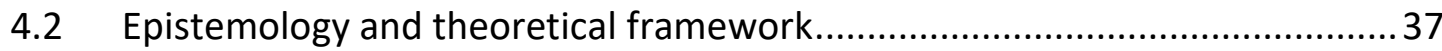

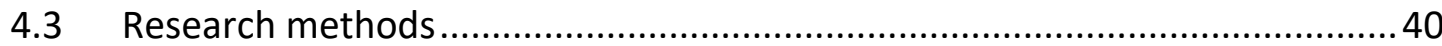

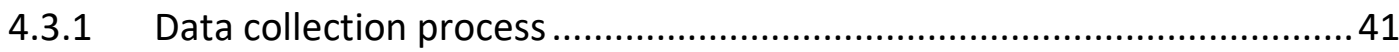

4.3.2 Selection of research site .............................................................. 41

4.3.3 Research fieldwork preparation ..................................................... 42

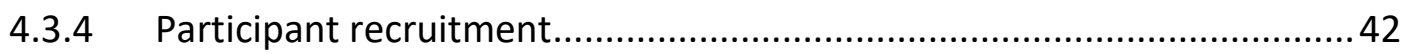

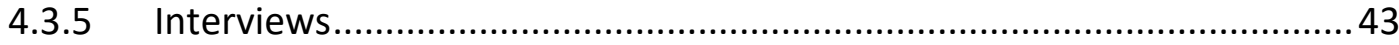

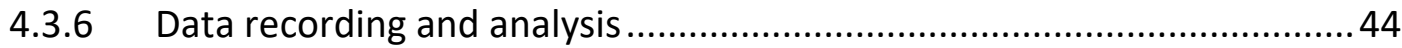

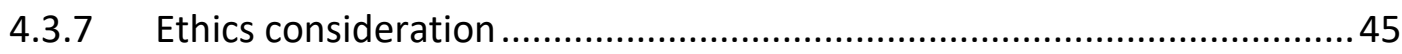

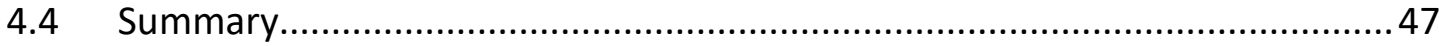

Chapter 5 Research Site Background and Key Research Findings ............................49

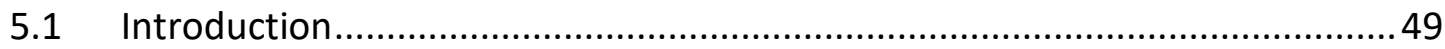

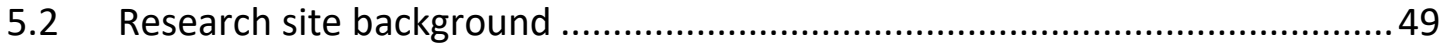

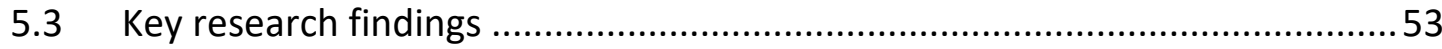

5.3.1 Access to land and natural resources ................................................... 53

5.3.2 Increased women's business and employment opportunities.................57

5.3.3 Increased women's dependency ...........................................................59

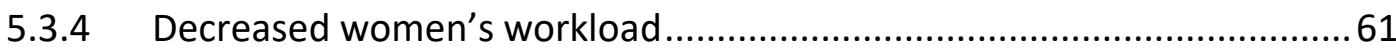

5.3.5 Decline in traditions and agricultural practices ....................................62 62

5.3.6 Changing patterns of household and relations.....................................64

5.3.7 Women's perceptions toward resettlement .........................................66

5.4 Summary

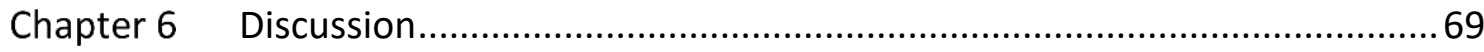

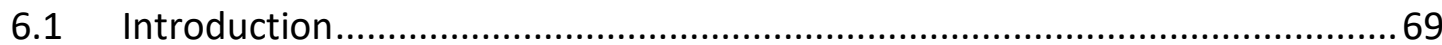

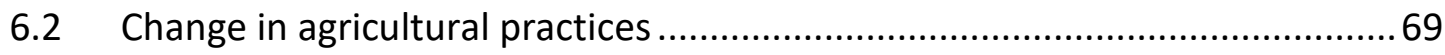

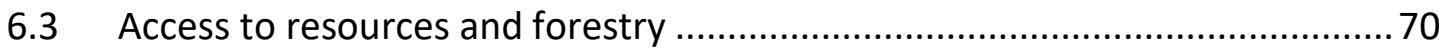

6.4 Access to new livelihood opportunities .......................................................... 73

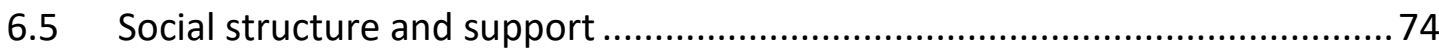

6.6 Women's perceptions of resettlement ........................................................ 75

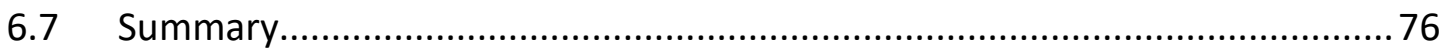

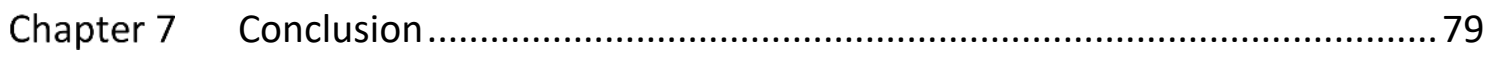

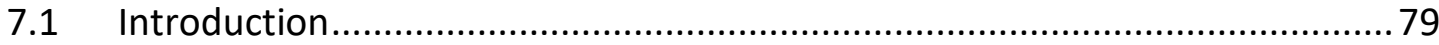

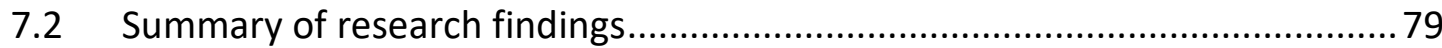




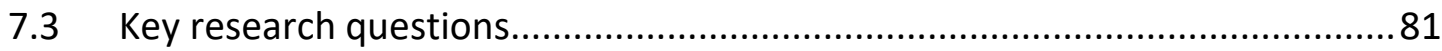

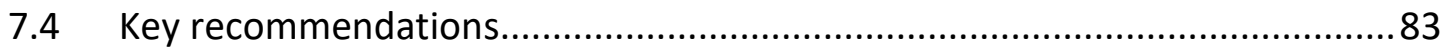

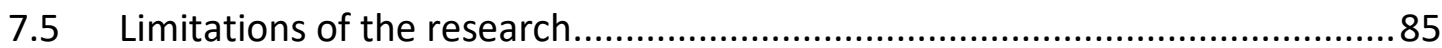

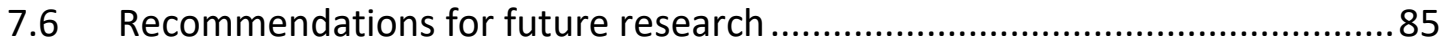

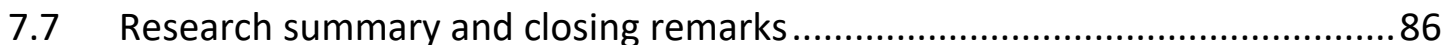

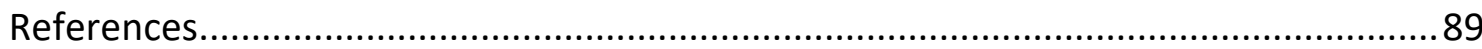

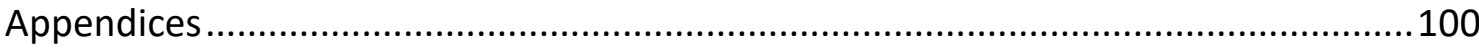


Page | viii 


\section{Abbreviations}

\begin{tabular}{|c|c|}
\hline ADB & Asian Development Bank \\
\hline DEB & Department of Energy Business \\
\hline EDL & Electricite Du Laos \\
\hline GAD & Gender and Development \\
\hline GDP & Gross Domestic Product \\
\hline GoL & Government of Laos \\
\hline HEC & Human Ethics Committee \\
\hline LNCAW & Lao National Commission for the Advancement of Women \\
\hline LSB & Lao Statistics Bureau \\
\hline LWU & Lao Women's Union \\
\hline MW & Megawatt \\
\hline NM3 & Nam Mang 3 \\
\hline NTFPs & Non-Timber Forest Products \\
\hline PKH & Phoukhaokhouay \\
\hline PKK & Phoukhaokeo \\
\hline STEA & Science Technology and Environment Agency \\
\hline UNDP & United Nations for Development Program \\
\hline VH & Vangheu \\
\hline VUW & Victoria University of Wellington \\
\hline WB & World Bank \\
\hline WCD & World Commission on Dams \\
\hline WID & Women in Development \\
\hline
\end{tabular}


Page | $\mathrm{x}$ 


\section{List of Figures}

Figure 3.1 Laos

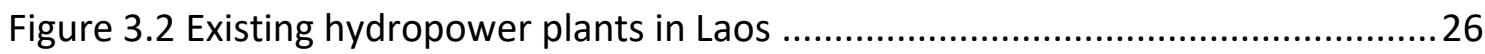

Figure 3.3 Planned hydropower projects to be completed before 2020 ....................28

Figure 5.1 Map of Nam Mang 3 hydropower dam .................................................. 51

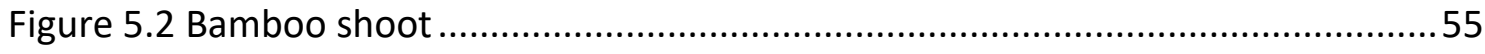

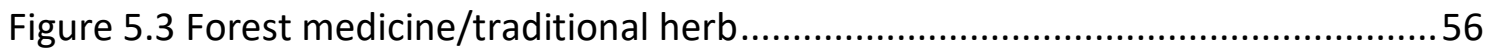

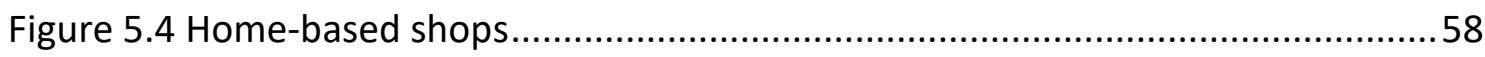

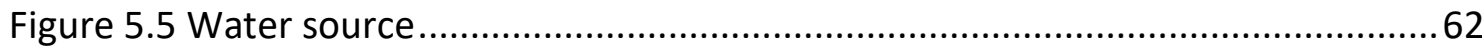


Page | xii 


\section{List of Tables}

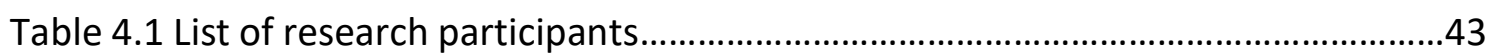


Page | xiv 


\section{Chapter 1 Introduction}

\subsection{Introduction}

This chapter outlines the motivations and general background behind this research. The research focuses on the key impacts of resettlement related to hydropower dam development in general and the impacts on women specifically. Following an initial statement of the research context and problem statement, the chapter outlines the research objectives and research questions. Before concluding, the research design, research framework and significance of this research will also be discussed.

\subsection{Research background}

Over the past 20 years, the production of electricity worldwide has increased rapidly and the demand for electricity is also rising due to economic development that extends to emerging economies. According to the World Commission on Dams (WCD) (2000, p. 8), there were about 45,000 large dams in more than 140 countries worldwide by the end of the $20^{\text {th }}$ century and many of these dams were in developing countries. For instance, around 22,000 dams were built in China alone, which is nearly half of the total dams around the world. In Southeast Asia, hydroelectric dam development has also increased rapidly in recent years due to the increase in power consumption and demand for energy exports to earn revenue, particularly in Laos, Cambodia, Myanmar and Vietnam (Sayatham, 2013). There are about 58 large dams currently under construction in Cambodia, Laos, Myanmar and Vietnam and 52 dams are in the planning phase (Bui and Schreinemachers, 2011, as cited in Bui, Schreinemachers, \& Berger, 2013).

With an increase in new dam construction projects in developing countries, environmental and social problems associated with these projects have become more sizeable (Fujikura \& Nakayama, 2009) and attracted much global attention. Dam construction generally impacts on communities who live in areas where the dams are constructed. Agricultural lands and forests are lost; homes may need to be relocated; and river-based livelihoods are particularly affected. Many different groups of communities might be affected while some of them have to be removed and resettled 
in new locations. For example, the Three Gorges Dam alone in China displaced 1.3 million people from the dam location (Sukhan \& Adrian, 2000). In India there have been around 16-38 million people displaced due to dam construction and in Vietnam there were about 200,000 people who were displaced due to hydropower dam construction up to 2011 (Bui et al., 2013 as cited in Sayatham, 2013). In Laos, 6,300 people were resettled to give way for the Nam Theun 2 hydropower dam alone (Becker, 2012, p.11). Globally there have been around 40 to 80 million people displaced from the construction of large dams (WCD, 2000, p. 104). Many of these displaced people were farmers, and they tended to continue their farming activities after resettlement. Unfortunately, in many cases livelihoods of these people were poorly reconstructed by hydroelectric project developers. This failure resulted in some resettled people selling the land that was allocated for them at resettlement areas and becoming either tenant farmers or migrants to a city in search of work (Fujikura \& Nakayama, 2009).

In addition, according to Downing (2002), the effects of resettlement on a displaced community involve the loss of both physical and non-physical assets. These include shelters, communities, productive land, income-earning properties and sources, subsistence, resources, cultural sites, social structures, networks and ties, and cultural identity as well as traditional social support networks. Consequently, issues associated with dam construction projects became international. The environmental and social concerns related to hydroelectric development projects became significant within global issues such as human rights and biodiversity (ibid).

More importantly, previous studies did not pay much attention to the impact of dams on different groups of people (Mehta and Srinivasan, 2000). Instead, the affected people from dam projects were regarded as a genderless entity, rather than recognising that women and men might have different interests and needs. However, evidence from many studies recently conducted to explore the impacts of large dams in different projects discovered that women experienced different impacts relative to men from displacement and resettlement (Lahiri-Dutt, 2012; Mehta \& Srinivasan, 2000; Parasuraman, 1993; Yong Ooi Lin, 2001). The impacts covered both social and economic aspects. Even though evidence from these studies suggested that differential impacts from hydropower dam development existed, many water engineers, administrators, and policy-makers persist in viewing "the community" or "the family" as a homogeneous 
category and ignore the complexity of the affected population particularly when gender roles, tasks, and power relations are taken into account (Lahiri-Dutt, 2012).

Laos is a small landlocked country located in South East Asia with a total population of almost 6.5 million (Lao Statistics Bureau, 2015). Per capita income was about US\$2,150 in 2016 (World Bank, 2016, p. 1). Laos is rich in natural resources and shares borders with five different countries: Cambodia, China, Myanmar, Thailand, and Vietnam. In addition, Laos has a multi-ethnic society with a high degree of diversity of culture and tradition (Sayatham, 2013). In addition, "as the country intercepts monsoons from two directions - from the Gulf of Thailand and the Gulf of Tonkin - precipitation is high and favourable for hydropower development" (Phonepraseuth, 2012, p. 5). This provides Laos with an opportunity to pursue the development of hydropower plants: to meet its domestic electricity consumption; and for export to neighbouring countries to earn national revenue such as Thailand, Vietnam, Cambodia, China and Myanmar where demand for electricity has been rapidly growing (DEPD, 2008, as cited in Phonepraseuth, 2012).

Electricity from hydropower plants was not produced in Laos until the late 1960s (DEPD, 2008). The first hydropower dam in Laos is Nam Ngum 1 dam which was put into operation in 1971 with a capacity of 155 MW of electricity production. However, by 2014 there were about 16 hydropower plants in the country in operation and they collectively produce about 3,000 MW (Sivongxay, 2015). Therefore, the energy sector become the third largest export earner for the country (NGPES, 2006; DEPD, 2008; as cited in Phonepraseuth, 2012). It has been estimated that the country has the potential to generate about $26,000 \mathrm{MW}$ (ibid). With this potential there are a number of hydropower plants to be constructed in the future (Sivongxay, 2015). Therefore, with the international experience, in Laos over the past years there have been many dams being constructed and operated and there will be more dams planned for construction in the future.

\subsection{Problem statement}

Development projects generally caused both positive and negative impacts on the environment and society around the project area. Some development projects, such as hydropower dams in particular, need to resettle people to new areas so that dams can 
be constructed. This can result in a number of implications for the livelihoods of resettled people. It is often found that the specific needs of these people have been inadequately addressed in resettlement program implementation (WCD, 2000). Moreover, constructing a hydropower dam always comes with costs and benefits that are not equally shared among those people (Wang, Lassoie, Dong, \& Morreale, 2013). For example, some affected groups of people have adapted better to the changes that took place after the construction of a dam while others were more exposed to impacts (Souksavath \& Maekawa, 2012). However, adaptation to their new livelihoods after the loss of their pre-resettlement livelihood assets has sometimes enabled these groups to sustain and modify their livelihood outcomes (Bui et al., 2013).

Over the past years there have been a number of studies on the impacts of hydropower projects and their implications in Laos. Results tend to be mixed. For example, a study of Souksavath and Maekawa (2012) on livelihood reconstruction of the resettled people from Nam Ngum 1 hydropower dam after more than 40 years of resettlement concluded that a village that received adequate infrastructure facilities, particularly road access and irrigation systems, has been better off in terms of livelihood restoration and livelihood conditions. However, a village that did not have adequate infrastructure has been worse off.

Nam Mang 3 dam is a multipurpose dam located in central Laos. The construction of this dam initially started in 2001 and was completed in 2005. The dam has created an approximately 1,000-hectare area of reservoir and affected people from three villages, with the land from two villages being flooded. The construction of this dam required the relocation of about 150 households from their villages to new areas that are closer to a small city (Sayatham \& Suhardiman, 2015). The movement of these people from their villages to new locations led to a change in their livelihoods and living conditions. For instance, some households had to change from raising large livestock (e.g. cattle and buffalo) to small livestock (e.g. chickens and pigs), and from slash and burn cultivation to permanent gardening and paddy cultivation. In addition, many households also experienced difficulties in access to natural resources. However, some families enjoyed the benefits that they derived from the opportunities available at the resettlement areas. For instance, due to closer and larger markets some resettled people could earn 
extra income from the sale of forest products; others could earn income from wage labour and small home-based businesses.

Previous studies by Chaleun and Associates (2008) and Sayatham (2013) reported that, with support and assistance from the project, the affected communities have been better off over time. The relocated villages now have convenient access to roads, markets, education and healthcare services and facilities, communication and other transport facilities. However, even though the resettled people have greater access to these services and facilities, many experienced difficulties in access to natural resources and continuation of some of their previous farming activities. In addition, international literature suggests that development projects like hydropower dams affect men and women differently. Even though there have been a number of studies on the effects of hydropower dams in Laos over the past years, there has been little done specifically on the gender impact of dams. Moreover, I have reviewed the available literature in the case of the Nam Mang 3 hydropower dam and found that there has not yet been any study previously conducted to explore how these changes have affected women. Due to this reason it is interesting and significant for this research to find out how the women from the resettled communities experienced their relocation due to the hydropower dam. More importantly, it is also interesting to explore if the needs of women have been met and their aspirations have changed since resettlement took place.

\subsection{Research objectives}

The primary objective of this research is to explore the impacts of resettlement from hydropower dam development on the lives of resettled women by using the case of Nam Mang 3 hydropower dam in Laos. Under this research objective, there are three specific aims and sets of questions.

\subsubsection{Primary research question}

This study aims to explore the impact of resettlement on women's lives and livelihoods. Therefore, the specific questions will be as follows:

How have women's lives and livelihoods been impacted by resettlement due to the Nam Mang 3 hydroelectric dam development project in Laos? 


\subsubsection{Sub-questions}

To clarify this main question, the following aims and sub-questions will also be addressed.

Aim 1: To explore the changes in livelihood activities of the resettled women since resettlement took place.

What have been the changes in the resettled women's livelihoods since resettlement?

Aim 2: To explore the changes in women's relationship with their community after resettlement.

How have women's relationships with their community changed since resettlement?

Aim 3: To explore whether resettlement has influenced the aspirations of resettled women

How have women's economic and social aspirations changed since resettlement?

\subsection{Research approach and methodology}

This research aims to explore the impact of resettlement due to hydropower dam construction on resettled women. In order to achieve the research objective and address the research questions, the Gender and Development (GAD) theoretical framework has been adopted and a qualitative methodological approach has been utilised. These methodologies can help explore issues regarding women participants' perspectives towards development projects. In addition, according to Mack, Woodsong, MacQueen, Guest, and Namey (2005), information regarding values, opinions and social context of a particular group can be obtained through qualitative research methodology. Along with these methodologies and framework I used semi-structured interviews as a field data collection technique. Overall, some 18 people were interviewed in depth for this research, comprising both men and women from the affected communities and some other key informants. With these frameworks, methodologies and techniques I was able to explore the impact of resettlement constructively with my research 
participants. These methodological approaches are discussed in greater detail in Chapter four.

\subsection{Research contribution}

This thesis aims to make several contributions to the body of literature on the impacts of dam construction. First, it sheds light on the social impacts of development projects, particularly hydropower, on people living in the affected areas. The research also indicates how the resettlement process, due to such projects, might affect the resettled communities particularly women, both positively and negatively.

This research offers the resettled women a voice in the resettlement process. Hydropower impacts experienced by the resettled communities are explored in a gender-sensitive manner. Through participation in this research, resettled women potentially have had the opportunity to contribute to future policies or resettlement programmes in other areas where hydropower dam construction will take place. In addition, the research also aims to contribute to the implementation of hydropower projects and resettlement processes so that future projects may be of more benefit to local communities. The results can also be used to identify conditions that need to be met by hydropower project operators so that the adverse effects on resettled communities are minimised while helping communities realise the potential benefits.

\subsection{Thesis outline}

This thesis consists of seven chapters. In brief, Chapters two and three will provide background information about issues related to the dam and resettlement which formulate an essential foundation for this research. Chapter four illustrates the process of data collection and analysis. Chapters five and six respectively present key research findings and a discussion of the key findings. Finally, the overall conclusion of this research will be provided in Chapter seven.

Chapter one introduces background information and the researcher's motivations to the choose the topic. It also provides contextual information of the research site which is the Nam Mang 3 hydropower dam in Laos and then the chapter ends with the introduction of research objectives and key research questions. 
Chapter two provides a general overview of dam development and its impact on the resettled communities in general and specifically to women. The chapter explores the potential impacts that the resettled women have faced due to relocation from hydropower dams.

Chapter three provides background information of hydropower dam development in Laos. This includes the provision of policy and regulations on resettlement of development projects. In addition, this chapter also presents general information about gender and women's development in Laos.

Chapter four describes the process of fieldwork preparation and the methodology used in this research. It also explains how the research was undertaken in the field. These include the process of how the researcher approached the research site, how research participants were recruited, and how data was collected and analysed. In addition, the chapter also discusses relevant ethical issues and processes.

Chapter five presents the main findings of this research. It explains how women from the resettled communities were impacted by the resettlement process of Nam Mang 3 hydropower project.

Chapter six provides discussion of the key findings that emerged from this research. This chapter brings all key findings and the literature identified in the earlier chapters together in order to examine to what extent women's lives are impacted by resettlement.

Chapter seven draws conclusions on the ideas gained from Chapters two, five, and six of this research to address the research aims and three questions. The chapter also delivers recommendations in relation to future improvement of hydropower resettlement as well as future research. 


\section{Chapter 2 Literature Review}

\subsection{Introduction}

This chapter aims to provide an understanding of the impact of resettlement on women from hydropower dams through the existing literature. The chapter will be divided into three parts. Firstly, it will begin by presenting a background of hydropower dams and the general consequences. Secondly, the impacts of resettlement on women will be provided. Finally, the chapter will conclude with the thesis's gap identification.

\subsection{Dams, displacement and development}

Over the past decades, there have been significant numbers of large dams constructed worldwide. In 1949 there were approximately 5,000 large dams globally of which more than half of these dams were located in the industrialized world (World Commission on Dams, as cited in Altinbilek, 2002; Mehta \& Srinivasan, 2000; Scudder, 1993). According to the figure provided by the WCD (2000), there were about 45,000 large dams located in more than 140 countries worldwide, with between 60 and 70 per cent in developing countries (WCD, p. 10).

Hydropower is one of the energy sources which has been considered reasonably inexpensive (Altinbilek, 2002) and 'cleaner' than other energy sources particularly energy from fossil fuel, as it does not produce emission or greenhouse gases (Yüksel, 2007). In addition, hydropower dams have the potential to produce efficient energy (USSD, 2008, as cited in Sivongxay, 2015) As a result, in many countries hydropower dams play an important role in sourcing domestic electricity. For instance, in Norway around 95 per cent of domestic electricity is from hydropower, 81 per cent in Brazil, and 59 per cent in Canada (Sivongxay, 2015).

Hydropower dams also pay an important contribution to socio-economic development, especially for a developing country. Hydropower dams can provide reliable and affordable electricity for industrial use and domestic consumption (Tshering \& Tamang, 2004), and can ensure national energy security (Kaunda \& Mtalo, 2013). Hydroelectric power increases the availability of electricity for domestic use and in return it stimulates 
economic activities which include industry and commerce (Adams, 2000, as cited in Sivongxay, 2015). In addition, hydropower projects also create employment opportunities during construction and operation (Sivongxay, 2015). For these reasons, hydropower is often seen as a tool to spur economic development and eradicate poverty in many developing countries. For example, in Bhutan, hydroelectricity sale, mainly to its neighbouring India, accounted for about 45 per cent of the gross revenue earned between 1997 and 2002 (Tshering \& Tamang, 2004).

Even though there are benefits that can be derived from construction of dams for the development of a nation, it is in conjunction with displacement of people and also the sacrifice of other resources. Globally, it has been estimated that between 40 million to 80 million people had been forced to leave their homes due to the construction of large dams (WCD, 2000, p. 104). For example, in China between 1950 and 1990 nearly 10.2 million people were displaced by dams while in India the figure lies between 16 million to 38 million people (Fernandes \& Paranjpye, 1997, p. 17 , as cited in WCD, 2000, p. 104). Excluding India and China, 134 completed dams displaced about 2.2 million people during the mid 1990s (McCully, 1996, p. 67). There is acknowledgment that development-induced displacement causes considerable social, economic and cultural disruption and losses for both the individuals and the communities (Scudder, 1993; Thukral, 1992; WCD, 2000).

\subsection{Gender, development and displacement}

Gender is most commonly used to refer to social roles, social relations and social practices (Gallin, Aronoff, \& Ferguson, 1991). Gender includes structuring of power and resources, and the ways in which certain groups and forms of knowledge have gained authority over others (Duerst \& Kelly 1995; Kurian 2002). Gender is a powerful social and cultural construct influencing the ways in which social relations are structured between men and women. Gender is central to how societies assign roles, responsibilities, resources and rights between men and women (Mehta \& Srinivasan 2000). It constitutes the entire gamut of relations that govern the social, cultural and economic exchanges between women and men in different arenas from the household to the community, state and multilateral agencies (Jackson \& Pearson, 2005). 
Gender is not merely about bodies, it also includes the institutionalisation of masculine and feminine values in the practices of organisations, institutions and the state. Gendered values and practices thus have the potential of marginalising certain groups of people, including third world peasants, tribes, women and poor. In the context of development projects, gender becomes especially significant for several reasons. Gender and class-based division of labor and the distribution of property and power, structure people's interactions with nature and in the process structure effects of environmental change on people and their responses to it (Agarwal, 1996). The differences in the divisions of power, labor and property, based upon perceived and ritualized gender differences, result in women and men of the same class experiencing the environment in different ways, hence having a different knowledge of the environment. For example, peasants and rural women, especially the poor, play a crucial role as providers, producers and managers. As such, these women experience displacement in a specifically gendered way.

Gender analysis also points to the way in which these development projects impact women and men differently. Several studies elaborate on vulnerable communities like women and children that tend to be impacted by displacement in ways that require an evaluation beyond monetary loss of land (Indra, 1999; Thukral, 1996). Additionally, in the unequal context of gender disparities tend to be further exacerbated.

\subsection{Resettlement and its impacts on women}

Resettlement is about the physical movement of people from one location to another location to enable a development intervention (Jain, 2005). According to the Asian Development Bank (ADB) (1995), resettlement can be classified into two different categories as voluntary and involuntary resettlement. They also noted "the difference between voluntary resettlement and involuntary resettlement is that the people who move voluntarily are generally self-selected, young and willing to take risks and pursue new opportunities and challenges. On the other hand, those who move involuntarily are people of all ages, outlooks and capabilities moving involuntarily without option but to give up their assets" (1995, p. 3). Unlike people who move because of environmental degradation or socio-economic reasons, those affected by development-induced 
resettlement are pushed out of their original locales without any option of staying (Jain, 2005). Involuntary resettlement involves economic and social losses from land being taken away and access to resources being restricted, along with the consequences from compensation and rehabilitation measures (World Bank, 2004). When people are forcibly moved, production systems may be dismantled, long-established residential settlements are disorganised, and kinship groupings are scattered. Many jobs and assets are lost. Informal social networks that are a part of daily sustenance systems providing mutual help in childcare, food security, revenue transfers, labour exchange and other basic sources of socio-economic support can collapse because of territorial dispersion (Yong Ooi Lin, 2001). Additionally, displaced people may be relocated to environments where they may not be able to apply their skills and reach their full potential; the competition for resources may be high and host communities may have different cultures (ADB, 1995, cited in Jain, 2005).

The construction of large dams have profound environmental, social, cultural, and economic consequences. Regardless of whether these consequences are positive or negative, they entail massive changes for the lives of women and men who are designated as project-affected persons (Mehta \& Srinivasan, 2000). Dam construction that involves displacement and resettlement can cause impoverishment risks which may affect various categories of vulnerable people differently depending on the sector in which displacement occurs, or on local circumstances. Some might be more vulnerable than others (Cernea, 1997). For instance, groups of resettled women have been found to experience more severe impacts (Feeney, 1995; Koenig, 1995, as cited in Cernea, 1997) in a similar way to tribal groups (Fernandes, 1991).

On a positive side, several empirical studies have reported that there are a number of improvements following displacement and resettlement to the affected population. These improvements include basic infrastructure such as accessible roads, water, electricity, healthcare, and education (Chareun \& Associate, 2008; Bui \& Schreinemachers, 2011), improving opportunities for the development of new livelihoods. In addition, studies conducted in three different countries: Zimbabwe, Laos, and Vietnam (in 2001, 2010, and 2013 respectively) found that the resettled communities were provided with the aforementioned facilities and services which could help them to improve some aspects of their community development and livelihoods 
after relocation (Sayatham, 2013). The case study from Zimbabwe further concluded that the overall impact of resettlement on agricultural production and rural poverty had been improved. The resettled households were mostly able to obtain higher production and achieve better income levels in comparison to households living in the same area (Sayatham, 2013). Another study that was conducted in Nam Theun 2 hydropower dam affected villages in Laos showed that 90 percent of respondents perceived their livelihood as improved since moving to resettlement areas, noting better access to water, electricity and road facilities (Phonepraseuth, 2012).

The availability of these facilities and services have benefited women as it helps reduce time spent on chores and improving nutrition (WCD, 2000, p. 116). In many areas, particularly in rural villages, access to electricity is fundamental for socio-economic development (Smits, 2012). Electricity not only provides light at night, but also supports other economic activities during evening time such as weaving and other handicrafts (Smits \& Bush, 2010). Such improvement can benefit women in many ways as it helps save their time from domestic activities, for example through enabling the use of electric appliances (Adams, 2000, cited in Sivongxay, 2015a). Therefore, when an improvement in living standards in impact areas is achieved, this can have a positive spill-over effect on gender equity (WCD, 2000, p. 116).

In some cases, the social impacts of dams might lead to more egalitarian gender relations. For example, research on a resettlement scheme in Zimbabwe showed that women tended to be less constrained by past kinship patterns and had better relations with their husbands (Koening, 1995, p. 25, cited in Mehta \& Srinivasan, 2000). However, a case study of a resettlement project in Vietnam found that resettlement caused a change in both social space and livelihoods which affected the gender relations in the Coho community. The study further concluded that changing from traditional subsistence to a modern livelihood and market-oriented system is not necessarily good for gender relations in a matrilineal society (Phuong, n.d).

However, resettlement also brings negative effects, including risk of impoverishment. According to Micheal Cernea (2000), in his 'impoverishment risk reconstruction', there are eight impoverishment risks following replacement and poorly handled resettlement. These impoverishment risks are 'landlessness, joblessness, homelessness, 
marginalisation, food insecurity, increased morbidity, loss of access to common property resources and community or social disarticulation'. These eight basic impoverishment risks may affect various categories of vulnerable people differently depending on the sector in which displacement occurs, or on local circumstances. Overall, resettlers at different locales may experience some or all of these eight impoverishment risks, with some more vulnerable than others. Displacement and resettlement in many cases not only results in physical dislocation, but also undermines the economic independence and social autonomy that women used to enjoy in their daily life prior to resettlement (Bisht, 2009). For example, resettlement that leads to a change in land use could cause negative impacts on women. As evidenced by empirical studies, reduction of land size and land quality is possible. For example, a case study conducted by Bui et al. (2013) in Vietnam showed that the resettled people and the host villagers had less land than before. Another study conducted in Laos also found a change in land use and land quality after resettlement (Phonepraseuth, 2012). This change affected the resettled women in a way that could push them to marginalization.

In addition to displacement, access to common property resources become limited (Cernea, 1990). In many countries around the world, local communities depend almost entirely for their livelihood on natural resource extraction, therefore losing areas to collect natural resource products is a huge loss (World Bank, 2010). Such loss also affects women in the resettlement sites disproportionately (Lahiri-Dutt, 2012). This is because women are more likely to utilise common property resources for domestic chores such as cooking and cleaning, so the loss of such common property can affect a woman's ability to maintain or sustain a household. In addition, women also depend on this forest-based work to generate their own independent income (Mehta \& Srinivasan, 2000), and also utilise the forest to maintain their knowledge regarding nutritional and medicinal properties of plants, roots, and trees (Yong Ooi Lin, 2001). Moreover, the burden of finding accessible alternative resources such as water, fuel wood, fodder, or wild vegetables once resettlement occurs remains a woman's responsibility (Yong Ooi Lin, 2001). Therefore, the loss of such common resources can affect not only women themselves in many aspects such as knowledge and skills, but also their families.

Women can even become poorer if displacement breaks up the household and kin group that provided them with economic and social support (Parasuraman, 1993). Studies 
show that pre-existing community and kinship groups are important for women for many reasons. For women in rural and tribal areas in particular kin relationships still constitute the prime avenue of access to scarce resources such as information, economic assistance and other social support (Dyson \& Moore, 1983, cited in Parasuraman, 1993). As it was found in a case study from Malaysia, prior to resettlement, families, relatives, and neighbours had been close-knit because of personal obligations and responsibilities towards one another in exchange for labor in farming (Yong Ooi Lin, 2001). Having been resettled, it was found that their traditional ways of living had changed and been replaced with resultant monetised economy. A study conducted by Yong Ooi Lin (2001) further elaborated that the traditional custodians of the rice spirit and other cultural ceremonies in relation to upland rice cultivation of women had been erased. Rice cultivation is fundamentally important for the rural community, and women in particular, who find it central to both their social and cultural lives. With new lifestyles and livelihoods imposed in the resettlement site, women find it difficult to work outside of their home and experienced a lack of support from family members where this was always possible prior to resettlement (Yong Ooi Lin, 2001).

In addition, disruption of social cohesion due to the breakdown of the community can have greater impact on women than men. In the case of communities affected by the Sardar Sarovar Project (SSP) in India, isolation from kinship structures because of increased transportation costs has led to increased insecurity and fear amongst women (Thukral, 1996). In some contexts, for example South Asia, women have less mobility than men (Mehta \& Srinivasan, 2000; Parasuraman, 1993). Any changes that occur in the social system impose more severe effects on women than men (Parasuraman, 1993). Displacement can have severe implications for the existing restricted mobility of women in a context where women are forced to spend more time on agricultural labour because of shrinking economic activities for the communities (cited in Mehta \& Srinivasan, 2000).

\subsection{Compensation, rehabilitation and the impacts on women}

The absence of appropriate development measures for compensation, resettlement, and rehabilitation of displaced people may: (i) cause severe long-term hardship impoverishment, and even decimation of the affected communities; (ii) adversely affect 
the host populations; or (iii) lead to severe environmental damage. Several public and private sector projects, such as hydropower dams or mines, cause involuntary population displacement but fail to relocate people in a sustainable manner and instead have caused their impoverishment. Social science research has discovered that one fundamental cause of such failures is the loss of asset and the insufficient financing of resettlement (Cernea, 2008).

According to Tofail and Kaidab (2015), a number of guidelines adopted by international organisations such as the World Bank and the Asian Development Bank involve financial compensation packages to all those resettled. The requirement recognises the loss of land and other properties including the livelihoods of the affected people. Such requirements have tended to be grounded in the core wisdom that if the basic material needs of people to be resettled were provided for in cash or in kind, then adequate attempts would have been made (McDonald, 2006). As such, until presently, compensation payments have been made as traditional relief for the dispossession, economic disruption, and income loss of the resettled people from development projects (M. M. Cernea, 2003). However, application of cash compensation can result in a number of problems. Some resettlers have not been able to sucessfully turn compensation cash into wealth and livelihood opportunities, meaning they could find themselves more impoverished than before resettlement (Cernea, 1996). Within the household, women tend to spend income received on the basic needs for their families for example, food, healthcare, education, etc., while men tend to spend it on consumer goods. Past studies have confirmed this behaviour where male resettlers are less likely to invest cash compensation in goods that will improve the overall well-being of the household (Gopal, 1992). Overall, such financial compensation packages seem appropriate to some extent, but can have questionable long-term outcomes. For instance, McDonald (2006) claims that resettled people who are given with cash usually ended up with impoverishment. Even in the case of land replacement the quality of replaced land has commonly been poor and insufficient to restore production (McDonald, 2006).

A number of case studies in China, India, and Africa demonstrate that compensation was not the only way to re-establish the livelihoods of resettled people (Chidmany, 2016). In China, according to Jing's (1997) review of the practices of three resettlement 
programmes, namely Xin'anjiang, Sanmenxia and Yongjing, he concluded that the resettled people were worse off compared to their neighbours who were not resettled. This was because of insufficient compensation (Jing, 1997). Webber and McDonald (2004) claim that their study of the Xiaolangdi resettlement in China discovered the resettled people were not satisfied with the amount of compensation cash received. In addition, in India, land compensation was made, but the land received was productively poor (McDonald, 2006). In Africa, McDonald (2006) showed that the compensation in

the Kiambere hydropower project in Kenya and the Akosomba dam was found insufficient so that it resulted in widespread social and economic impoverishment. As a result, these studies concluded that the impoverishment risks related to resettlement were not avoided through compensatory means (McDonald, 2006).

In sum, undertaking the restoration of livelihoods associated with involuntary resettlement through compensation alone can lead to negative outcomes (McDonald, Webber, \& Yuefang, 2008). Therefore, implementing involuntary resettlement through a combination of 'restoring' and 'improving' components of quality of life to support resettled people's lives in the long-term is seen to be a better solution than only financial compensation (Tofail \& Kaidab, 2015, p. 204).

\subsection{Research gaps}

Though the social impacts of large dams have been extensively recognised, especially with respect to involuntary resettlement and displacement (Cernea, 1997; Scudder, 1995, cited in Mehta \& Srinivasan, 2000). However, the direct or indirect impacts of dams on the lives and livelihoods of different people across the entire river basin have not attracted much attention, with even less known about the difference in experience between men and women (Mehta \& Srinivasan, 2000). In addition, literature on large dams usually views the affected people from a dam project as a genderless entity, rather than women and men may have different interests and aspirations. Similarly, the household is not seen as a place where women and men both co-operate with each other or are in conflict with each other (Sen, 1990, cited in Mehta \& Srinivasan, 2000). Also, the community earmarked for either compensation or benefits is viewed as homogenous with male members usually being targeted. Therefore, dams have been built and their impacts, positive or negative, have been analysed in a gender-blind way 
as though differences between women and men in the household or community do not exist (Mehta \& Srinivasan, 2000).

In the earlier days, there were no detailed studies of a gendered analysis of forced displacement and resettlement programms. However, the works of some studies: Mehta (2000); Mehta and Srinivasan (2000); and Parasurama (1993), have recently advanced our understanding of gender and forced displacement and outlined the adverse impacts on women. Studies in many different locations show that women are impacted differently from displacement and resettlement (Bisht, 2009; Lahiri-Dutt, 2012; Mehta \& Srinivasan, 2000; Parasuraman, 1993; Yong Ooi Lin, 2001). The loss of land, common property resources, and the breakdown of a community as a result of displacement and resettlement severely affects women and tribal people. Women become more marginalized at the resettlement areas as their skills are not effective and their dependency is high. In Laos, there have been several studies conducted to explore the impacts of hydropower dam creation and associated resettlement. Some found positive impacts on the affected communities particularly the income of the resettled due to the availability of services and facilities at the resettlement site (Phonepraseuth, 2012; Souksavath \& Nakayama, 2013). On the other hand, a number of negative impacts were also discovered such as food insecurity; reduction of income; loss of access to common property resources; as well as health issues (International Rivers, 2010; Souksavath \& Nakayama, 2013) and also less land for production (Sayatham \& Suhardiman, 2015).

Nonetheless, there is often little clarity about how hydropower development in Laos impacts men and women differently and to what extent women are impacted. As I have reviewed the available literature in this area an obvious gap has emerged. Therefore, in this thesis, I will address the gap by focusing my exploration on the lived experience of the resettled women following the construction of the Nam Mang 3 hydropower project in Laos. 


\section{Chapter 3 Laos, Hydropower, and Women's Development in Laos}

\subsection{Introduction}

This chapter consists of three main sections. The first section provides information regarding the location, demographic and socio-economic characteristics of Laos. The second illustrates the impacts of government development policies under the New Economic Mechanism which was adopted in the late 1980s, including development options through the harnessing of natural resources particularly in the energy sector. The chapter then summarises issues and policies for women development and women's empowerment in Laos.

\subsection{Geography, population, and socio-economic characteristics}

Lao People's Democratic Republic (Lao PDR), or Laos, is a small landlocked country. It is located at the centre of the Mekong sub-region and also in the dynamic South-East Asian region (Phouxay, Malmberg, \& Tollefsen, 2010). Laos shares borders with five different countries namely China in the north, Cambodia in the south, Myanmar and Thailand in the west, and Vietnam in the east. Around two thirds of the country is mountainous, with large sparsely populated areas intersected by river valleys, and upland plateaus (Lao Statistics Bureau, 2008). Approximately 41 percent of total land area is covered by forest (Prime Minister's Office, 2005, as cited in Fujita \& Phanvilay, 2008).

Laos has an abundance of natural resources. These include water, forests and minerals (Lao Statistics Bureau, 2008). As most of Laos is covered by forests and mountains, a number of big rivers exist (Sivongxay, 2015), contributing 35 percent of the flow of the Mekong river (Matthews, 2012; Mekong River Commission, 2005; Phomsoupha, 2009). The Mekong is one of the most important rivers in Asia (Liu, Lu, Liu, \& Jin, 2007) and the dominant river in Southeast Asia. It runs through six countries namely China, Myanmar, Thailand, Laos, Cambodia, and Vietnam (Liu et al., 2007; Mekong River Commission, 2005). 
Laos has a total population of 6.9 million with a high proportion of the population living in rural areas (67 percent of the total population in 2015) (Lao Statistics Bureau, 2015). Laos is endowed with a wealth of ethnic and cultural diversity (Lao Statistics Bureau, 2008). Overall, there are 49 sub-ethnic groups which are classified into four ethnolinguistic categories: Lao-Tai, Mon-Khmer, Hmong-Mien, and Chinese-Tibetan (Pholsena, 2002). The largest ethnic group, the Lao-Tai, make up 62.4 percent of the total population, followed by Mon-Khmer (23.7 percent), Hmong-Mien (9.7 percent), and Chinese-Tibetan (2.9 percent) (Lao Statistics Bureau, 2015).

These different ethnic groups tend to have distinct livelihoods and live in different locations across the country and speak different languages. These locations tend to overlap with altitude (Lao Statistics Bureau, 2008). For instance, the Lao-Tai traditionally live in lowland areas with agricultural systems based on wet-rice cultivation (LSB, 2008; Hatsadong, Douangsila, and Gibson, 2006) and trade, mainly along the river banks (Hatsadong et al., 2006). The Mon-Khmer currently live in many midland areas (LSB, 2008; Simana \& Preisig, 2006) and depend on upland farming systems (Simana \& Preisig, 2006). Chine-Tibet and Hmong-Mien groups tend to live in highland areas mainly in the northern part of Laos and engage in upland agricultural practices (LSB, 2008) as well as raising livestock (Sengxua, 2006). Such diverse ethnic groups and multiple cultures suggest that development policy in Laos must be holistic and inclusive so that it serves the interests and needs of this diverse cultural society. 
Figure 3.1 Laos

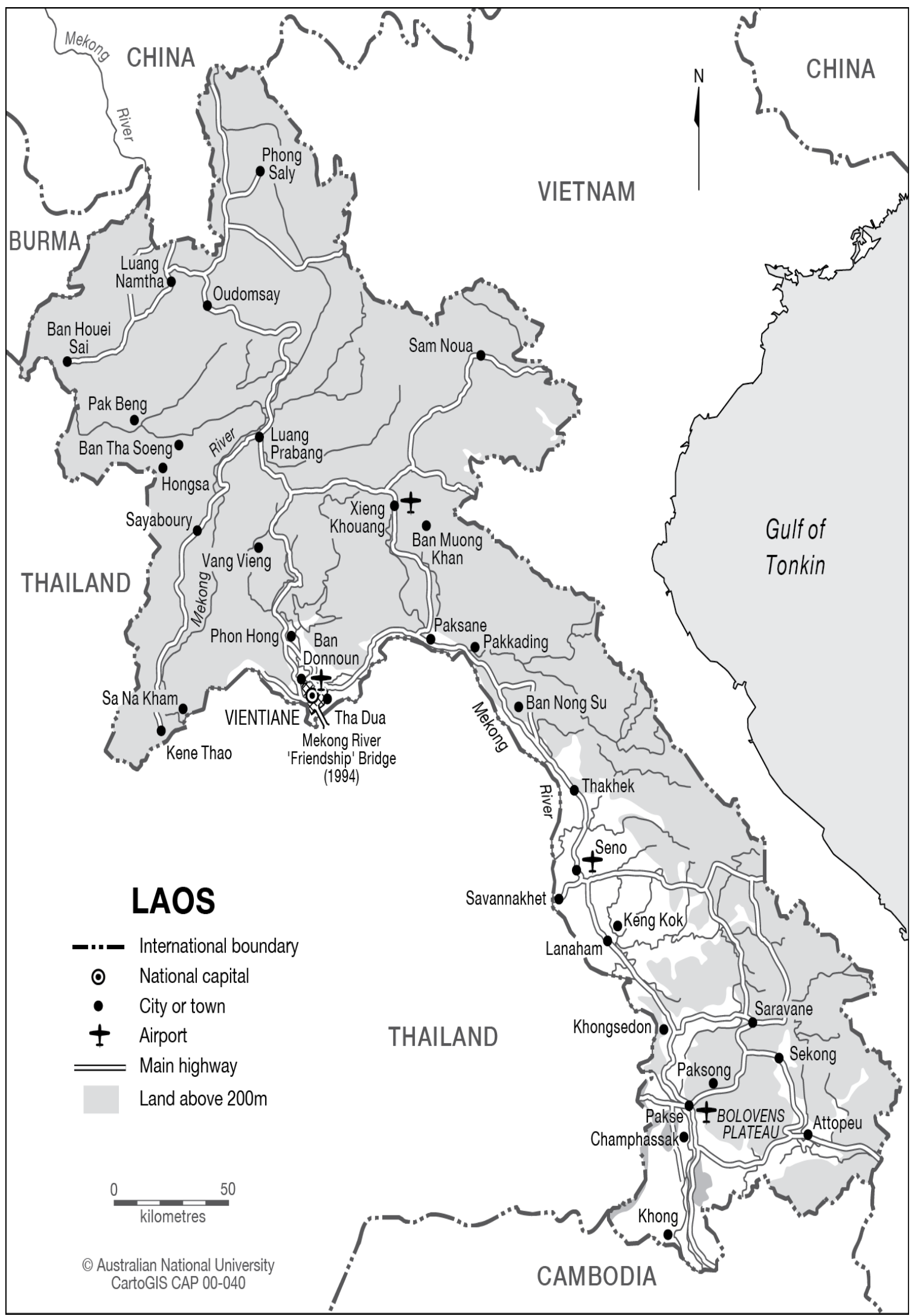

Source: Australian National University (2012) 
As the country is landlocked, Laos experiences significant difficulties and challenges in access to international markets (World Bank, 1996, 2005, as cited in Soukkaseum, 2017). In addition, much of the country's territory is mountainous (Lao Statistics Bureau, 2015). These hard to access areas bring challenges for development, meaning some people remain in poverty as they cannot fully access social services provided by the government, such as education and healthcare (Fujita, 2006). Furthermore, poor transport and communications also cut off the rural population from economic opportunities in urban areas (Fane, 2006). Over the past decades, the government has tackled these challenges by extending and improving infrastructure such as roads to many villages in rural areas. Improving road conditions and connectivity along with reasonable public transportation are critically important for improving access to healthcare services and hence the health status in rural communities (UNDP, 2017). Yet recent figures show that less than 60 percent of rural residents have access to roads (Lao Statistics Bureau, 2015).

Laos has become one of the fastest growing economies in East Asia and the Pacific with an average of 7.8 percent growth rate of Gross Domestic Product (GDP) over the last ten years (World Bank, 2017). The contribution of industry and services to GDP is also increasing, with about 36 per cent and 43 per cent respectively in 2016 (LBS, 2017). This economic performance can be traced back to the time of independence from colonisation in 1975. Right after independence, the Lao economy was developed based on the centrally-planned economic model and this model continued until 1985 (Phimphanthavong, 2012). Over this period the government realised that the economy was not performing satisfactorily (Phimphanthavong, 2012). Subsequently a period of new economic reform, which is known as the New Economic Mechanism, began in 1986 aiming to shift from a centrally planned economy to market-oriented economy. This reform had two basic political goals: (i) open market policy; and (ii) the introduction of market economic principles (Phimphanthavong, 2012). Since the introduction of these New Economic Mechanisms, the socio-economic situation in Laos has gradually changed. The transition from a subsistence to a market-oriented economy has been consistently encouraged. Investment in areas of infrastructure, hydropower, mining, transportation, construction and education has been enabled (Rigg, 2005, as cited in Phouxay et al., 2010). 
This New Economic Mechanism has significant impacts on both social and economic development of Laos. In terms of economic development, Laos has seen a significant increase in investment in the public and private sectors and has achieved greater economic cooperation within the region and globally (Phimphanthavong, 2012). The economies of many urban areas have improved rapidly as a result of the amount of foreign investment emerging in sectors such as garment manufacturing, commerce, and tourism (Phouxay et al., 2010). Such investment has led to an increased number of young people migrating to urban areas to seek employment and education (Phouxay et al., 2010).

Along with economic development, Laos has also made significant progress on a number of Millennium Development Goals (MDGs), ${ }^{1}$ including halving poverty, reducing hunger, and improving education and health outcomes (World Bank, 2017). The figures in the 2013 Laos MDGs show that the proportion of the population living below the national poverty line dropped from 46 percent in 1993 to about 28 percent in 2007 and further down to 23.2 percent by 2013 (UNDP, 2013). However, poverty reductions have been far from uniform across the country, and poverty rates have actually increased in some regions in the past (Fane, 2006). In addition, other social indicators like the literacy rate also increased from about 75 percent to 83 percent for the population aged 6 years old and over. However, the female literacy rate remains lower than the male literacy rate.

\subsection{Hydropower and socio-economic development policy}

With favourable hydrological and topographical conditions, Laos has considerable potential to develop and produce hydroelectricity to meet its domestic needs and also export to nearby countries where demand for electricity is on the rise (Phomsoupha, 2009). It has been estimated that the country has the potential to generate electricity of about 26,000 Megawatts (MW) through the application of hydropower (Phomsoupha, 2009). However, electricity from hydropower plants in Laos was not produced or initiated until the late 1960s (Phomsoupha, 2009) when the country's first large scale hydropower project, the 155 MW Nam Ngum 1 (NN1) in Vientiane Province near the Capital City of Laos, was completed and put into operation in 1971 (Pholsena

\footnotetext{
${ }^{1}$ Now superseded by the Sustainable Development Goals
} 
\& Phonekeo, 2004). This first hydropower dam produces electricity mainly for export (70 to 80 percent of production is exported to neighbouring Thailand) and the rest is for domestic electrification (Delang \& Toro, 2011, p. 570, as cited in Sivongxay, 2015).

Recently, the Government of Laos (GoL) has pursued policies that will see a major expansion of its hydropower production capacity by exploiting its hydropower potential (Sivongxay, 2015). The GoL has articulated its vision to strategically take advantage of its geographical position, which repositions Laos not as being 'landlocked', but being a 'land-link' to Asia through closer integration with the Mekong economy (Phanvilay, 2010, as cited in Sivongxay, 2015). Moreover, the government has also considered the development of its hydroelectric power sector as a central strategy for economic growth and poverty reduction (Green \& Baird, 2016). Since the late 1980s, Laos has received technical assistance and advice from international and multinational organisations such as the ADB, World Bank, United Nations Development Programme (UNDP) and bilateral Western donors about its development opportunities through hydropower development (Middleton, Garcia, \& Foran, 2009). Harnessing natural resources particularly around hydropower is seen as one of the few options for national industrialisation and trading (Phanvilay, 2000, as cited in Sivongxay, 2015).

In the early days of hydropower development, the needs for financial resources were met by International Financial Institutions (IFIs), but their support has been limited in recent years. Therefore, the involvement of the private sector has been considered necessary and promoted through a BOOT approach (Phomsoupha, 2009). Due to limited financial resources to invest in power generation, since 1993 the GoL has signed a number of agreements with neighbouring countries including Thailand and Vietnam to support the development of hydropower projects (Phomsoupha, 2009). The power purchase scheme with Thailand was extended from 1,500 MW in 1993 to 7,000 MW by 2020 (Phomsoupha, 2009). The government also signed agreements with Vietnam to supply electric power up to 5,000 MW by 2020 from the initial 2,000 MW in 2006 and also to Cambodia with 1,500 MW electricity by 2020 (Sivongxay, Greiner, \& Garnett, 2017).

Development of the country's hydropower potential is realised on both a large and small scale. The smaller projects are developed for domestic power sales with concessional 
loans and bilateral aid, and owned and operated by the Laotian state-owned electricity utility, which is known as Electricite du Laos (EdL). The power generating capacity for these small projects is up to $100 \mathrm{MW}$ (Sivongxay, 2015). On the other hand, the large scale projects have the capacity of producing power greater than $100 \mathrm{MW}$ (Pholsena \& Phonekeo, 2004). These large hydropower projects were suggested to be developed by the private sector under ВООТ contractual arrangements by which the government takes an equity share in the project. By doing so, the GoL is able to generate benefit from concession royalties, taxes and earn revenues from the sale of electricity. In return this financial resource could be further utilised for the development of the nation (Middleton et al., 2009).

With the vision of taking advantage of its geographical position and repositioning away from being 'landlocked', but being a 'land link', Laos has identified 100 potential sites both on the Mekong mainstream and its tributaries for the construction of hydropower dams. Together these sites have the potential to generate electricity up to $26,000 \mathrm{MW}$ (Middleton et al., 2009). By 2014, 16 hydropower dams on the Mekong tributaries were in operation and collectively produce about 3,000 MW of electricity (DEB, 2014, as cited in Sivongxay, 2015). By 2016 there were 22 hydropower projects in operation on the tributaries of the Mekong where 9 of these projects are owned by the state and the other 13 are operated under complex foreign shareholder entities or independent power producers (IPPs) (Sivongxay et al., 2017). 
Figure 3.2 Existing hydropower plants in Laos

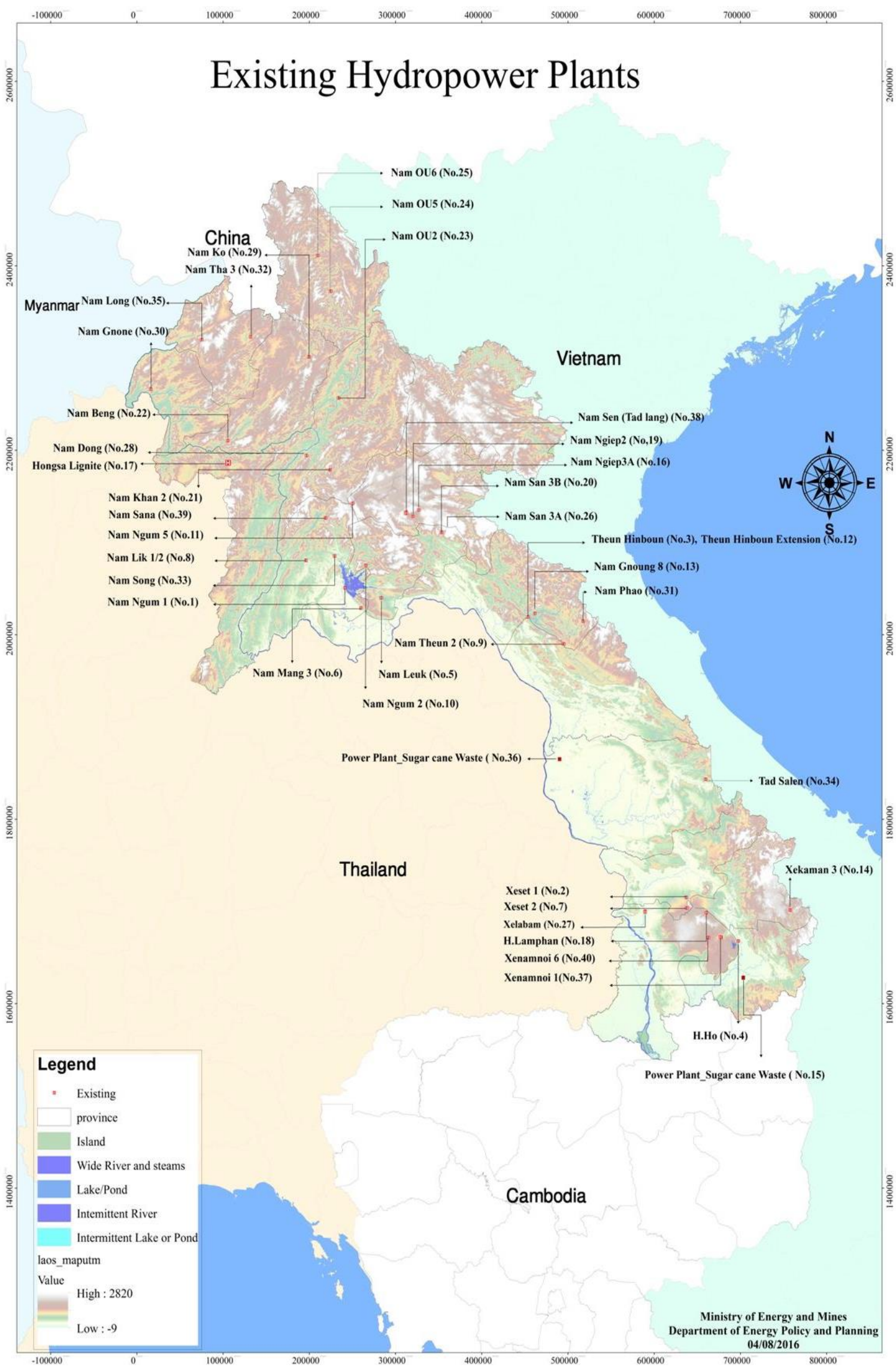

Source: Ministry of Energy and Mines (2016) 
There are also plans for further expansion of the sector with 60 or more export-oriented hydropower projects which are planned or are being constructed (Sivongxay, 2015). These include nine hydropower plants on the Mekong mainstream (Matthews, 2012), (see Fig. 3.3). Therefore, exports in the power sector have become the third largest source of income for the government and account for approximately 30 per cent of all Laos' export earnings (Green \& Baird, 2016; Phomsoupha, 2009). 
Figure 3.3 Planned hydropower projects to be completed before 2020

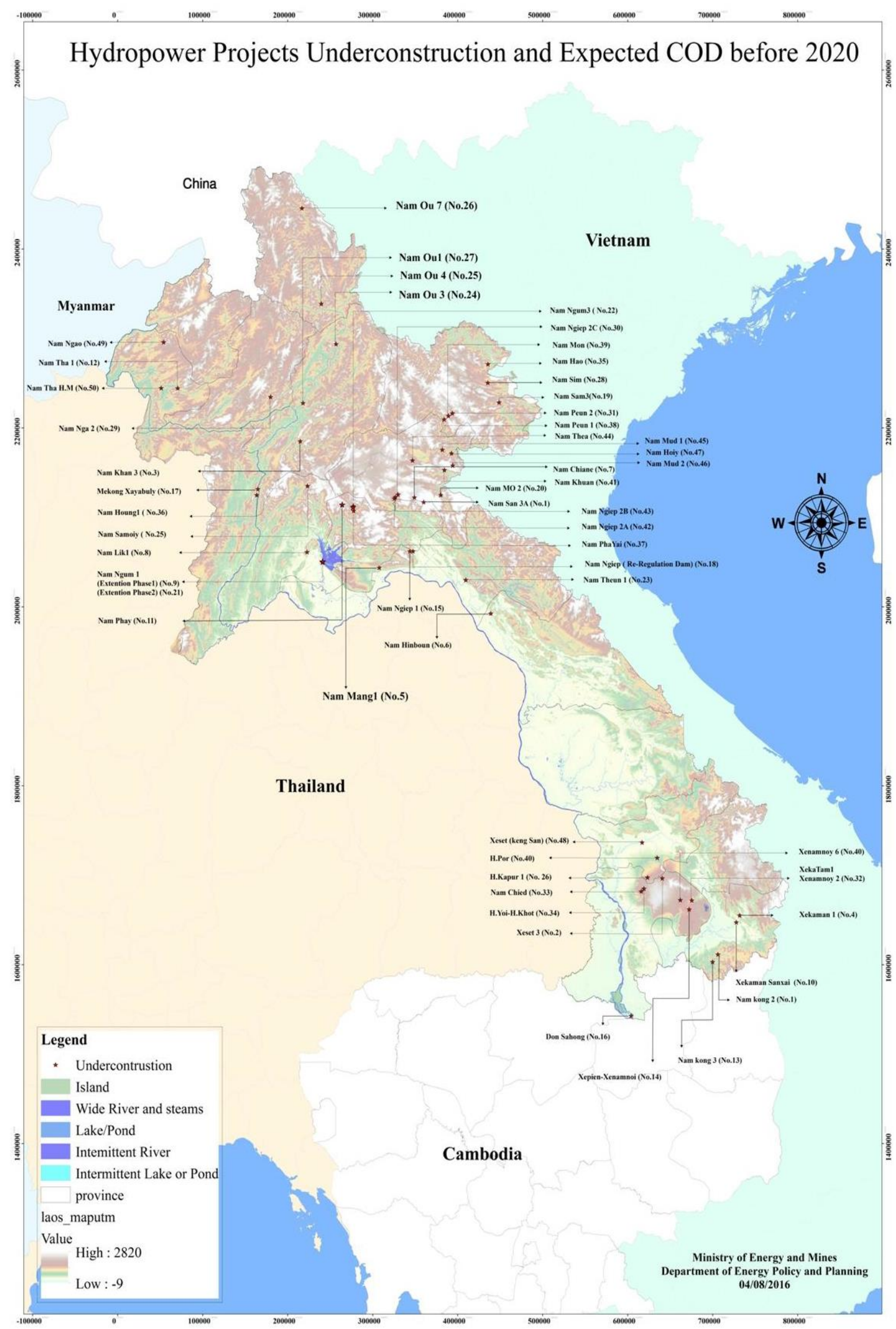

Source: Ministry of Energy and Mines (2016) 


\subsection{Hydropower regulations}

The Government position is that sound hydropower development can lead to economic prosperity and increased well-being. The GoL accepts that a comprehensive regulatory and legal framework is necessary, including for management of environmental impacts. Many of the laws and regulations relevant to the Laos' hydropower sector were enacted concurrently with the country's pursuit of hydropower expansion in the 2000s. These include the Electricity Law 1997, National Environmental Impact Assessment (EIA) Regulation 2000, the Regulation on Implementing Environmental Assessment for Electricity Projects 2000, and the Environmental Management Standards for Electricity Projects 2001. These regulations state that an affected person is entitled to receive direct or indirect benefits from dam construction (Sivongxay, 2015).

The Electricity Law 1997 states that a license is necessary for the production of electricity in Laos (Sivongxay, 2015). The Law also has provisions to protect endangered species and demand environmental conservation (GoL, 1997, as cited in Sivongxay, 2015). The Environmental Protection Law 1999 issues guidelines for the country's Environmental management of development projects (Souksavath, 2011, as cited in Sivongxay, 2015). The National EIA Regulation of 2000 mandates that impact assessments (IAs) are required for any Lao hydropower project (STEA, 2000, as cited in Sivongxay, 2015).

Prior to building consent, an ex-ante Social Impact Assessment (SIA) must be carried out by hydropower developers, either in conjunction with the EIA or as an additional process. The Water Resource and Environmental Agency was established in 2007 to deal with all environmental issues within Laos. This also include the granting of environmental compliance certificates to hydropower developers after reviewing their IAs (Sivongxay, 2015).

Recently, institutional frameworks relevant to compensation and resettlement from development projects have been issued including the (i) decree on compensation and resettlement of people affected by development projects 2005 (STEA, 2005a); and (ii) Regulations for implementing the decree on compensation and resettlement of people affected by development projects (STEA, 2005a). This decree was issued to define principles, rules, and measures for mitigation of adverse social impacts and compensation for damages that result from involuntary acquisition or repossession of 
land and fixed or movable assets, including changes in land use, and the restriction of access to community or natural resources affecting community livelihood and income sources. In short, the decree intends to ensure that project affected people are compensated and assisted to improve or maintain their pre-project status by all means. The decree covers all development projects including government, domestic private, or foreign development projects that require acquisition of land, land use rights, property on land or other land related issues that might affect community livelihood. When development projects have the potential to cause adverse socio-economic impacts, the decree states that the project owners have the responsibility to: (i) assess the damages and determine compensations for affected people; (ii) make every attempt to avoid or minimise potential negative impacts; (iii) financially support all resettlement and compensation activities; and (iv) provide necessary support to people with disabilities and finally ensure that resettlement processes are participatory. To implement this decree regulations were also issued. The regulations state that all processes of a development project need to be in line with the decree on compensation and resettlement of people affected by development projects. Other issues are related to how project owners facilitate public participation, information disclosure or circulation, and consultation into shaping the overall resettlement process. The regulations highlight the potential role of local authorities to engage in more transparent and deliberative decision making through participation and community taking an active role in the resettlement planning and implementation (STEA, 2005b).

\subsection{Women in Laos}

Laos' strong economic growth in recent times has lifted a number of poor women and men out of poverty. This improvement has benefited women across the country in many areas such as education, health, and economic opportunities.

Since liberalisation of the economy, progress has been made to close the inequality between men and women in education. For example, primary enrolment rates of girls have improved, as have adult literacy rates for women. However, despite these improvements, fewer girls are enrolled than boys at all levels in school. Primary girls' enrolment improved from 77 percent in 1991 to 88 percent per 100 boys in 2009 . Similarly, adult literacy has increased from 48 per cent for women in 1995 to 70 percent 
in 2012; However, the rate for women is still lower than that of men, of whom 85 per cent are literate. Nationally, gender gaps in school enrolment rates have narrowed (Asian Development Bank \& World Bank, 2012).

Women and men both enjoy the benefits from improved access to water and sanitation. However, their access also varies significantly depending on location. For instance, people in more remote and typically poorer areas have less access compared to those in urban areas (ADB \& WB, 2012). In areas where access is limited, the burden of water collection remains heavily on the shoulders of women and girls. Women are also generally responsible for family health, hygiene and food security, which suffer from limited access to water and sanitation services (ADB \& WB, 2012). In addition, clean water and sanitation are essential public services and are also necessary for improving health and educational outcomes, especially for women and girls. Figures show that from 1995 to 2008 the proportion of the Lao population accessing improved drinking water sources increased from 44 per cent to 67 per cent, while the proportion using an improved sanitation facility rose from 18 percent to 63 percent (ADB \& WB, 2012). Data, however, shows that geographic differences. For instance, only 23 percent of households in remote areas without access roads have access to safe water compared to 88 percent in urban areas. In the case of sanitation, 38 percent of the rural population has access to improved sanitation facilities compared to 87 per cent in urban areas (ADB \& WB, 2012). Moreover, the maternal mortality rate in Laos also dropped, but at a slow pace which is seen not yet on track to achieve the 2015 MDG target (ADB \& WB, 2012).

Women's engagement in both formal and informal sectors has also increased. Notably women are increasingly seen to run or help run small businesses. Nationwide, household businesses headed by women slightly outnumber those headed by men, but in rural areas the opposite is true (ADB \& WB, 2012). Results from the national enterprise survey conducted by the WB in 2009 show that about 31 percent of businesses were partly or fully owned by females. In addition, a Deutsche Gesellschaft für Internationale Zusammenarbeit (GIZ) survey undertaken in five provinces found that the share of businesses owned or managed by women rose from 36 percent in 2005 to 41 percent in 2009 (ADB \& WB, 2012). 
However, access to markets and market information is still difficult for many entrepreneurs in Laos, including women. In more remote areas where many non-Lao ethnic groups are concentrated, access to markets and financial services is very limited (ADB \& WB, 2012). Traditional norms limiting women's mobility can further restrict their access to markets. Poor public infrastructure also adds to the costs of small enterprises such as handicraft production, in which women predominate. Women's lower levels of literacy and Lao (official) language proficiency particularly disadvantage them in accessing market information. Overall, an expanding private sector is creating opportunities for entrepreneurs, but women often experience more difficulty than men accessing these prospects (ADB \& WB, 2012).

In rural areas agricultural crops are essential for survival and also provide rural people with cash incomes. Women conduct all kinds of farming activities - sometimes with men and sometimes without men. Depending on the agricultural cycle, men and women's work varies during the year (Ireson \& Moreno, 2004). For example, traditionally in agricultural work in Laos, men plough and prepare seedbeds, whereas more than half of the transplanting of rice, weeding, harvesting, threshing and post-harvest operations are carried out by women. The practice of shifting cultivation is even more demanding on women and is very hard work, since they have to walk long distances to the rice fields and then transport rice and other crops back home for family consumption (GRID, 2005).

In addition, women's status differs depending on their ethnicity. For example, the women of the majority ethnic group Lao-Tai are generally seen to obtain a higher status than women of other minority ethnic groups, since the matrilocal and matrilinear systems of the Lao-Tai offer women some important roles in the family (Linuma, 1992, as cited in Khouangvichit, 2010). Generally, in Lao-Tai society young married couples will live with the wife's family and women inherit family properties, particularly land, and enjoy certain power in the family (Khouangvichit, 2010). By contrast, some other ethnic groups tend to follow patrilinear kinship rules and practice patrilocal traditions. For example, for the Hmong, women are considered members of the husband's clan after marriage (Thomson and Sally, 1993, as cited in Khouangvichit, 2010) and women traditionally have to live with their husbands' family after getting married. 
The government of Laos realises the need for women and men to have equal rights in all aspects of society - political, economic, cultural, social, and within the family. However, in practice Lao women remain poorer, less educated, and have access to fewer opportunities than men. As a consequence, the participation of Lao women in the process of decision-making remains limited, both at the national and local levels. Therefore, to make significant progress in eradicating poverty and implementing its Socio-Economic Development Plan, the National Growth and Poverty Eradication Strategy (NGPES) that the Lao National Assembly endorsed in 2003 has four povertyfocused areas: agriculture/forestry, education, health, and transportation (GRID, 2006). In addition, the NGPES also identifies several inter-sectoral priorities including gender equity and environmental conservation, and provides a gender strategy linked to each of the key areas (GRID, 2006).

In Laos, strategies for women's empowerment and gender equality are hightlighted in government policy. The government has recognised gender as a cross-cutting issue (GRID, 2005, as cited in Khouangvichit, 2010). Officially, the legal framework for gender equality is written in the constitution promulgated in 1991. The constitution clearly stated that men and women are equal in all aspects including politics, the economy, and cultural, social and family life. In the constitution, many articles guarantee women's equality and rights between men and women, and between husband and wife regarding family properties (Khouangvichit, 2010). The policy on women's empowerment resulted in a number of action plans and activities. For example, the birth spacing policy which was adopted by the government in 1995 was delivered to control the growth of population. At the same time, one of the objectives was to shorten women's time in their reproductive role, and to increase their time in productive work (Khouangvichit, 2010).

The policy and strategies in the $6^{\text {th }}$ Five-year Plan of Socio-Economic Development (2006-2010) considered gender equality as one of the important components of poverty eradication strategies. The government acknowledged that the country cannot eradicate poverty if the active engagement of women, particularly women of minority ethnic groups is absent (Khouangvichit, 2010). To achieve gender equality in all aspects; politics, the economy, and cultural, social and family life, four strategies for gender equality were established: (i) support to women's economic activities; (ii) improvement 
of women's accessibility to basic services; (iii) involvement of women in local decisionmaking; and (iv) increase in women's participation and their needs into development policies and plans (Khouangvichit, 2010).

In order to improve gender equality and lift up women's status, the government of Laos formally assigned the Lao Women's Union (LWU) and Lao National Commission for the Advancement of Women (NCAW) as responsible agencies. The LWU is the only institution that is constitutionally and politically mandated to represent Lao women of all ethnic groups and to protect women's rights and interests. The LWU took roots in the Lao Patriotic Women Association founded in 1955, which historically mobilised women to participate in the struggle for national independence. Its main responsibility is to improve the living conditions and status of Lao women (GRID, 2006). The LWU promotes and monitors the implementation of women's development programmes in compliance with the Party's and Government's policies, the constitution, and laws related to ensuring equal rights between women and men (GRID, 2006). The organisation endeavours to put gender issues on the agenda of every government sector development plan, and as such enables women to participate in policy and decisionmaking. The LWU also focuses on socio-economic development at the grassroots level to improve the living conditions of women and their families (GRID, 2006).

Apart from the LWU, the Lao NCAW was established in 2002 aiming to take the lead in mainstreaming gender concerns at the national, provincial, district and village levels. The Lao NCAW is different from LWU in that the Lao NCAW is a state organisation, but both are committed to protecting the rights and interests of Lao women and to bring about gender equality in all aspects of life in Lao society, across all ethnic groups (GRID, 2006). The roles and tasks of the Lao NCAW are to: (i) assist the government in formulating national policy guidance and strategic plans of action to promote women's advancement and gender equality in all spheres and at all levels of society; and (ii) act as the focal point and coordinate closely with local authorities and international organisations' concerns for the implementation of the party and government policy on the promotion of gender equality and the elimination of all forms of discrimination against women (ibid). 


\subsection{Summary}

Immediately after independence in 1975 the national development of Laos followed the socialist economic model, adopting and applying a centrally-planned economy. A decade later, the New Economic Mechanism was adopted by which the economy has been gradually shifted from centrally-planned to market-oriented. Since the implementation of this economic mechanism, Laos has experienced a gradual change in both the political and economic situation. The economy has steadily grown and achieved high annual GDP growth recently. As Laos is located in the centre of the dynamic SouthEast Asian region, and with its rich natural resources, this has provided an opportunity to develop its economy through exploitation of its natural resources. Therefore, hydropower development is one of the options for the government to generate revenue from exports and eradicate poverty through domestic electrification. Progress in both social and economic development has been made.

Regarding gender issues women typically have different roles to men within the family and in agriculture. There are differences among the major ethnic groups. However, gender gaps across many spheres still persist including politics, the economy, and decision-making in general. As such the government of Laos has adopted policies and strategies to promote gender equality and women's empowerment in the country. 
Page | 36 


\section{Chapter 4 Epistemology, Theoretical Framework and Research Methods}

\subsection{Introduction}

The preceding chapter provided an understanding of the impact of resettlement from a hydropower dam by drawing on the existing literature. This chapter will present the theoretical framework adopted, methodologies applied, and methods used to collect data in the field. The chapter will explain the epistemology and theoretical framework used in this research. It then follows with a description of both data collection methods and research ethical issues.

\subsection{Epistemology and theoretical framework}

Research design is influenced by many factors. This research was based on social constructivist epistemology which believes that realities are constructed socially. The term epistemology refers to the study of how knowledge is constructed and how objects are understood by different knowers. In addition, Hull (2015) describes epistemology as the justifications that we make regarding what we think is true. Over the past decades, truth or realities have been discovered through different paradigms. Some seek understanding independently from the phenomenon or the object being studied while others explore through day-to-day interactions and the meanings made out of the individuals involved (Lapan, Quartaroli, \& Riemer, 2011, pp. 7-8).

In research, epistemology is significant as it informs the research process particularly related to methodologies that are applied and how knowledge can be gathered and interpreted accordingly (Murray \& Overton, 2014). In addition, researchers choose a research methodology based on their worldview, leading to adopt whether qualitative, quantitative or mixed approaches (Creswell, 2014).

I decided to apply social constructivist epistemology in this research because of my belief that knowledge is created from interaction between me, the researcher, and my 
research participants (Guba \& Lincoln, 1994, pp. 110-111). Knowledge is not an object or 'something out there to be revealed', but it is humanly or socially constructed (Cope, 2002, p. 43). Therefore, if knowledge is created by people, there must be multiple perspectives, explanations, and practices of knowledge (ibid). it also follows that knowledge is also not something that we can passively or actively acquire because we are always engaged in its production and interpretation (ibid).

Feminist epistemology involves how the consideration of gender influences what 'counts' as knowledge, how knowledge is legitimised, and how knowledge is reproduced and represented to others. This means not only hearing 'women's voices' but also thinking about how gender as a set of social relations affects both men's and women's responses in the research framework, how the genders of interviewers and respondents might affect the data, and how research results are circulated to academic audiences and the public (Cope, 2002, p. 44). In addition, feminist epistemology also requires thinking about how socially constructed gender roles, norms, and relations influence the production of knowledge. If the production of knowledge is an active process involving differently situated human actors, we would expect that people's various experiences, identities, and social locations will influence what they count as knowledge and how they participate in its production and legitimisation (ibid). Therefore, given the objectives of my research I will partially apply social constructivist epistemology because I value my research participants' experiences as knowledge (Creswell, 2014) and I also take into account the feminist epistemology view which claims that knowledge is partial, subjective and it is subject to the way it is constructed (Sultana, 2007).

There are a number of theoretical frameworks potentially useful for exploring the subordination of women and implications for the economic and social roles as well as the status of women. All coming largely from feminist perspectives, there are several key theories which include Women in Development (WID) and Gender and Development (GAD). Before coming to the conclusion of adopting a GAD theoretical framework for this research, I will first provide different feminist perspectives.

According to liberal feminists, women's subordination and underrepresentation derived from social norms that limit women's access to education, employment and institutions (Whitworth, 1994). Therefore, liberal feminists aim to overcome women's 
subordination by promoting equal rights and opportunities for men and women through advocacy for changes to legislation and social policy (Maynard, 1995). With this attempt, liberal feminism has helped spark significant change for women in many areas, particularly politics and in the public sphere (Whitworth, 1994).

With the influence of liberal feminism, the WID approach was initiated in the 1970s aiming to advance women's decision making in development policy (Young, 2008). This initiative was inspired by women's movements for equal rights and status, and research on women's roles in economic development in poor countries. The WID approach is used therefore to challenge the stereotypes and conventional sexual divisions of labour in order to promote equity for women in all sectors and achieve economic efficiency (Razavi \& Miller, 1995). However, according to Rathgeber (1990), the WID approach is seen as more connected to modernisation theory and focuses on the productive aspects of the contributions of women regardless of the reproductive part of their lives.

The GAD approach emerged in the 1980s from the standpoint of socialist feminism and as a result of the perceived failures and limitations of the WID approach, particularly the criticism that WID failed to adequately address gender inequality. GAD focuses on gender relations both in the labour force and in the reproductive sphere (Visvanathan, 1997). Through gender relations, multiple roles of women - reproductive, productive and community - can be understood. According to Kabeer (1994), the GAD approach accommodates new strategies for feminist intervention enabling feminists to identify shortcomings in official policies. Even though GAD and WID are different, they both focus on women (Young, 1997). In addition, GAD also pays attention to the social relations between men and women and uses these relations as a category to analyse and consider men as potential supporters of women (ibid). Furthermore, Young also adds that the GAD approach "views women as active agents and not passive recipients of development" (1997, p. 51). GAD also underscores the importance of the local community participation in providing support for women (Young, 1997, p. 53). Thus, there is a need for women to organise themselves into a more effective political voice so that their right can be strengthened, and their decision-making power can increase.

Importantly, GAD suggests the importance of the state's role in supporting women's empowerment. It posits that the state, in most developing nations, can play both roles 
as employer of labour and distributor of social capital to socially necessary ends (Young, 1997, p. 53). It highlights the responsibility of the government to provide social capital for the care of and maintenance for new generations. For instance, they can improve social expenditure on education, health, and training in order to set up conditions for future economic growth. However, by doing so it refuses the point made for the production of future generations that it is totally the responsibility of individuals as a matter of social construction (ibid). Support is necessary at all levels of the state from local to central rather than from central government solely. This strategy entails that women have little voice politically or power to bargain at all levels: national, regional and local (ibid).

Additionally, GAD also highlights the importance of "bringing men back in" that provided not only a bureaucratic strategy but a new analytical focus (Jaquette \& Staudt, 2006). Instead of placing the focus just on women as a uniform group, GAD underlined the differences among women and focused on gender conflict. Issues of violence against women have become more significant for women's movements globally and GAD supporters have indicated the importance of improving women's access to resources in an environment where men are losing jobs and status creates male resentment and, in some cases, violence (ibid).

\subsection{Research methods}

This research uses qualitative methods because of the nature of the research topic and philosophy underpinning this research. Research using qualitative methods provides a lens to explore marginalised groups of people, particularly women (Creswell, 2014). (Flick, 2009) also argues that qualitative research methods allow women's voices to be heard, brought into the forefront and their goals to be realised. In addition, Creswell adds that 'this lens becomes an advocacy perspective that shapes the types of questions asked, informs how data is collected and analysed, and provides a call for action or change" (Creswell, 2014, p. 64). Moreover, qualitative research and feminist research are seen as more connected in a way that they both pay attention to the voices and needs of women (Flick, 2009). Because this research is to explore and understand women's lived experiences and viewpoints of their lives regarding the intervention of a development project, qualitative research methods are appropriate. With this method, 
I choose to collect data through semi-structured interviews and to supplement this with secondary data.

\subsubsection{Data collection process}

To achieve the research objectives, both primary and secondary data were collected from the research location and various sources. The gathering of data in the field took about three months: between June and early September 2017. The primary data collection was carried out in the three affected villages through semi-structured interviews with both male and female participants. Simultaneously, secondary data, both published and unpublished, was obtained from different sources such as the Nam Mang 3 hydropower project office, Ministry of Energy and Mines, Ministry of Environment and Natural Resources, and the Lao Women's Union. In addition, before going to the field I had conducted an analysis of relevant documents, particularly project documents, government policy documents related to hydropower and resettlement, and other relevant previous research papers. By doing this, I gained a better understanding of the context of my research location, its profile, and the background to the resettlement process.

\subsubsection{Selection of research site}

There are several advantages to undertaking research in my home country. Firstly, doing research at home offered me an opportunity to learn, reflect, and share my knowledge and understanding with the communities I was researching in. Secondly, my research aims could contribute to the efforts of the Lao Government to improve and enhancing women's status and living conditions. Finally, doing research in my home country provided me with convenience and familiarity regarding aspects such as location, language, culture and values which also helped me to gain access to the location of research as well as those being researched.

I selected my particular research site based on the nature and objective of my research which were to explore the impact of hydropower resettlement on resettled women. With this aim I found that the existing Nam Mang 3 hydropower project had also relocated many people including women and children. Secondly, in the existing literature, there has not been any research undertaken on this topic and in this particular 
location. Finally, the selection was also based on recommendations provided by previous research for future research.

\subsubsection{Research fieldwork preparation}

Prior to beginning the fieldwork there were different steps that I followed. Firstly, I applied for and received field research human ethics approval from Victoria University of Wellington's (VUW) Human Ethics Committee (HEC). Secondly, once the approval letter was obtained, I requested official permission from the relevant organisation, which was the Electricite Du Laos (EDL-Gen) based in Vientiane, to do my fieldwork in the targeted field areas. The Nam Mang 3 hydropower project office, which is based on site, was then informed by the EDL-Gen through an official note. In addition, village authorities of the targeted villages were coordinated and informed through official permission letters issued by the Nam Mang 3 hydropower project office. Before commencing the fieldwork and actual interviews, I first met with village authorities to provide information regarding the purposes of my research including procedure and conditions for selecting my research participants.

\subsubsection{Participant recruitment}

To select my research participants, I first had a meeting with the village authorities to inform them of my research purpose, and to explain the process and technique that I planned to use to select my participants. The primary technique that I applied to recruit my research participants was the 'snowball' technique which is also known as the 'respondent-driven' sampling technique (Heckathorn \& Jeffri, 2003, as cited in Berg \& Lune, 2012). This technique advises that new participants are recruited through suggestions of previous participants until interviewing is finished (Berg \& Lune, 2012). As suggested by Lee (1993, as cited in Berg \& Lune, 2012) applying this technique provides the opportunity to access participants with different backgrounds and those who would otherwise be out of reach. In addition, I was reluctant to ask for the intervention of local authorities in the recruitment of participants. This was to minimise the risks of having involuntary participants and questions answered in a manner different to the participants' own ways (Willis, 2006). My local connections also helped 
me to liaise with participants, socialise, introduce myself, and develop a certain level of trust.

I also hired a research assistant who acted as gatekeeper. This facilitated research participants to become more welcoming and my interview was therefore more relaxed and friendly. This was aided by my research assistant's background given he had grown up with the research community and shared a similar social and cultural background to those researched. In many interviews, I found that my research participants, particularly the women, felt relaxed and comfortable (as I could see from their facial expressions and laughter). In addition, interviewees tended to contribute more once they saw their male partners enjoy their conversation with my research assistant in the distance (my research assistant told me some of my interviewees' male partners were his old friends). Therefore, having a local male research assistant was beneficial as it seemed to help minimise any perceived differences between myself or the interviewer and interviewees.

Table 4.1 List of research participants

\begin{tabular}{|l|c|c|c|}
\hline \multicolumn{1}{|c|}{ Village and NM3 Office } & No. of Respondent & Male & Female \\
\hline Phoukhaokeo & 4 & 1 & 3 \\
\hline Phoukhaokhouay & 7 & 2 & 5 \\
\hline Vangheu & 7 & 2 & 5 \\
\hline EDL & 1 & 1 & 0 \\
\hline Total & 19 & 6 & 13 \\
\hline
\end{tabular}

\subsubsection{Interviews}

Interviews are one of the methods used to collect first hand data in the field. This method is commonly used in development research (Willis, 2006). An interview is not just 'having a chat', but involves face-to-face conversation between the researcher and the researched ( Dunn, 2005, as cited in Hay, 2005). Applying this method the researcher can obtain information regarding opinions, views and experiences from different perspectives (class, ethnicity, age and sexuality) (Dunn, 2005). In addition, with face-to- 
face conversations, I could check and confirm understandings and opinions with my research participants on different issues.

Interviews can be undertaken in many forms. However, in this research, given its own objectives and timeframe, I decided to use the semi-structured interview as my method to gather primary information in the field. Semi-structured interviews provide a guide consisting of themes, or a checklist, which helps engagement with my research participants throughout the interview process (see appendices 4.1 and 4.2). Semistructured interviews allow an opportunity to welcome new and unexpected questioning as the interview unfolds. In addition, semi-structured interviews enable the researcher to lead the conversation. This meant that I could redirect the conversation if it was found to be irrelevant to the research topics (Dunn, 2005). Furthermore, for some research participants, such as officials from government offices or companies, a certain degree of formality was necessary to encourage participation (Willis, 2006). For example, more formal interviewing was necessary for participants from the hydropower project office.

This research involved 18 participants, both male (6) and female (12), from the targeted communities. My interview checklist and schedule were prepared before commencing fieldwork. Based on the nature of my research I decided to have separate interview checklists or question guides for different groups of research participants (see appendix 2). With the checklist, I managed my interviews with participants by allowing the conversation to flow naturally, but with intervention (when appropriate) of additional questions. I also often asked my research participants during interviews to clarify and explain with more detail on points that I still had doubt or ideas that I found important and interesting.

\subsubsection{Data recording and analysis}

There are many different ways to collect, record, and analyse data from the research field work. In this research, the researcher applied semi-structured interviews as a technique to collect raw data from the field. With this technique, information was recorded in the form of note taking and voice recording. Interview notes and voice recordings were then transcribed. Since the interviews were conducted in local languages, I carefully translated the notes from local languages into English daily. I also 
listened to voice recordings, in addition to notes, so that I was able to capture some important aspects that were missed from the interview notes as well as to clarify the original meanings. Most importantly, as data safety is important for the protection of the participants, I decided to replace the names of individuals with pseudonyms. I also stored all interview notes and recordings in a secure place. Once the fieldwork was completed, data was analysed as soon as possible to prevent loss of information. The analysis results and interpretation were conducted in the form of manual coding and themes.

\subsubsection{Ethics consideration}

Ethical issues must be throroughly considered when conducting research with human subjects. In this research I carefully and sensitively considered all ethical issues and applied ethical guidelines throughout my research process. The following is to explain how I put these into practice ranging from document preparation to the actual fieldwork and output of this research.

\section{Consent and confidentiality}

Before commencing my research fieldwork, I first applied for ethics approval from the HEC of VUW. The application required me to provide details of my research process particularly: how I planned to approach my research participants; how I would ensure my research participants were effectively informed; and their consents obtained to the best of the participants' understanding; as well as how I would avoid risks that may occur to my research participants, and myself as the researcher. In addition, two very important forms that were necessary when undertaking my research ethically were the consent form and the participation information sheet (see appendices $3.1 ; 3.2 ; 3.3 ; 3.4$ ). Because my research was conducted in my home country, these forms were translated into the Lao language. This translation was performed carefully to ensure all aspects and meanings were covered to avoid misunderstandings.

With ethics approval and a supporting letter from my supervisor (see Appendices 1 and 2 respectively), permission from EDL was sought before the actual fieldwork began (see Appendix 6). This official permission letter was helpful in two aspects. First, it helped me to gain access to the research locations and research participants. Second, it helped 
build confidence and trust with the research participants given I was formally approved to undertake the research.

Once the research participants were selected through the 'snowballing' technique, the research participants were introduced to: the objectives of my research; confidentiality; the right to refuse participation; and the process of note taking and voice recording. I also always asked permission from my participants when I wanted to have the interview voice-recorded. In every case, the research participant was asked to sign the consent form or give verbal consent before the interview could proceed. However, in many interviews the participants provided verbal/oral consent instead of signed consent given their limited ability to write. The interview audio recordings and consent forms as well as notes from the interview were then kept confidentially and in a secureplace which only my supervisor and I could access. In addition, all materials including interview notes will be destroyed two years after the completion of this thesis. At the same time, my participants' real names were not used anywhere in this research.

I realised that confidentiality in this research was important. According to Wiles, Crow, Heath, and Charles (2008), there are different ways to protect the confidentiality of participants. These included omitting data and changing key characteristics of participants. In addition, I also applied "pseudonyms" to ensure that participants' real names were not used anywhere in the research. More importantly, there were no opinions that were attributed to participants in any way that could identify participants in the published results.

\section{Positionality}

The term positionality encompasses how I hold my position including but not limited to cultural, political, social and academic aspects of my identity, in relation to those of my research participants, my gatekeepers and other people's identities (Gregory et al., 2009 , p. 556, as cited in Koy, 2016). In addition, and in compliance with the ethical principles of the HEC, being aware of positionality and power relations and being able to reflect on these in my research process ensured more ethical knowledge production (Chacko, 2004; Sultana, 2007). 
According to Sultana (2007), to undertake research, researchers have to consider the differences between themselves and the research participants, and their perceptions towards the identity of the researchers to allow for the inclusion of multiple positionalities in a more meaningful way. In this regard, I was also aware of my gender as a male and positions as both an insider and an outsider.

I realised my position as an insider given that I was born in Laos, speak the same language, and understand the culture of my research participants. I could observe this during my fieldwork that my research participants were more open and interested in my research when they knew about my background. However, I also found myself in the position of an outsider. As a researcher educated both inside and outside the country, I become an outsider to some extent. For instance, during my fieldwork I sometimes experienced that my research participants did not understand some words that I spoke. Sometimes, I was looked at differently, from them due to the way I dressed. These aspects helped me to continue reflecting on my positionality throughout my fieldwork. (Neuman, 2012) argues that it is valuable for the researcher to continue reflecting throughout the research process by acknowledging that the research participants would respond according to how they perceive the researcher's position and how they relate to the researcher's background. In relation to that, I was also honest with myself about the position I was holding and continued to build trust with the research participants.

\subsection{Summary}

In summary, qualitative methods, particularly the semi-structured interviews were used for the research. Epistemology is informed by feminist perspectives and GAD will be utilised as a theoretical framework or 'lens' of interpretation. Through these I can address the research questions and achieve research objectives. 
Page | 48 


\section{Chapter 5 Research Site Background and Key Research Findings}

\subsection{Introduction}

In the previous chapter I elaborated on the process of data collection and the framework I used in this research. This chapter will present the findings of this research. The major findings found in this research are: (i) changes in access to land and resources; (ii) an increase in women's business and employment opportunities; (iii) an increase in women's dependency; (iv) a decrease in women's workload; and (v) a change in traditional and agricultural practices. First, however, my research site is introduced.

\subsection{Research site background}

The Nam Mang 3 hydropower project is located in Vientiane Province about 70 kilometres from Vientiane. This multipurpose dam (both irrigation and power generation) was constructed in 2001 and completed in 2005 with the total cost of USD 63 million. It is owned and operated by the state power utility - Electricite Du Laos (EDL). The construction of the Nam Mang 3 dam was jointly financed by the Government of Laos (GoL) which contributed 20 percent with the other 80 percent being a loan from the Export and Import (EXIM) Bank of China (Sayatham \& Suhardiman, 2015) where the China International Water and Electric Corporation (CWE) was contracted to construct the project (Chareun and Associates, 2008).

The construction work was initially started in 2001, but without undertaking an assessment of the Environmental Impact or conduting public consultation (Sayatham \& Suhardiman, 2015). With pressure from international organisations; the World Bank and $A D B$ in particular, construction stopped. Following this halt in construction assessments were conducted: the Environment Emergency Mitigation Plan (EEMP) and an Environmental Impact Assessment-Environmental Mitigation Plan-Social Action Plan (EIA-EMP-SAP). These were then developed before construction continued in 2002 (Chareun and Associates, 2008; Sayatham \& Suhardiman, 2015). 
The dam required a 1,000-hectare reservoir which affected people living in three villages: Phoukhaokeo (PKK), Phoukhaokhouay (PKH), and Vunghue (VH). However, villagers in PKK and PKH (about 150 households) were required to be resettled to new locations due to their village land being flooded by the reservoir (Sayatham \& Suhardiman, 2015). There were eventually about 80 households who agreed to move to the resettlement locations approximately 20 kilometres from their old villages, but close to a small town and a paved road. Around 55 households decided to move to VH village which is located in the plateau and closer to their original village (NM3 hydropower project office, July 2017). 
Figure 5.1 Map of Nam Mang 3 hydropower dam

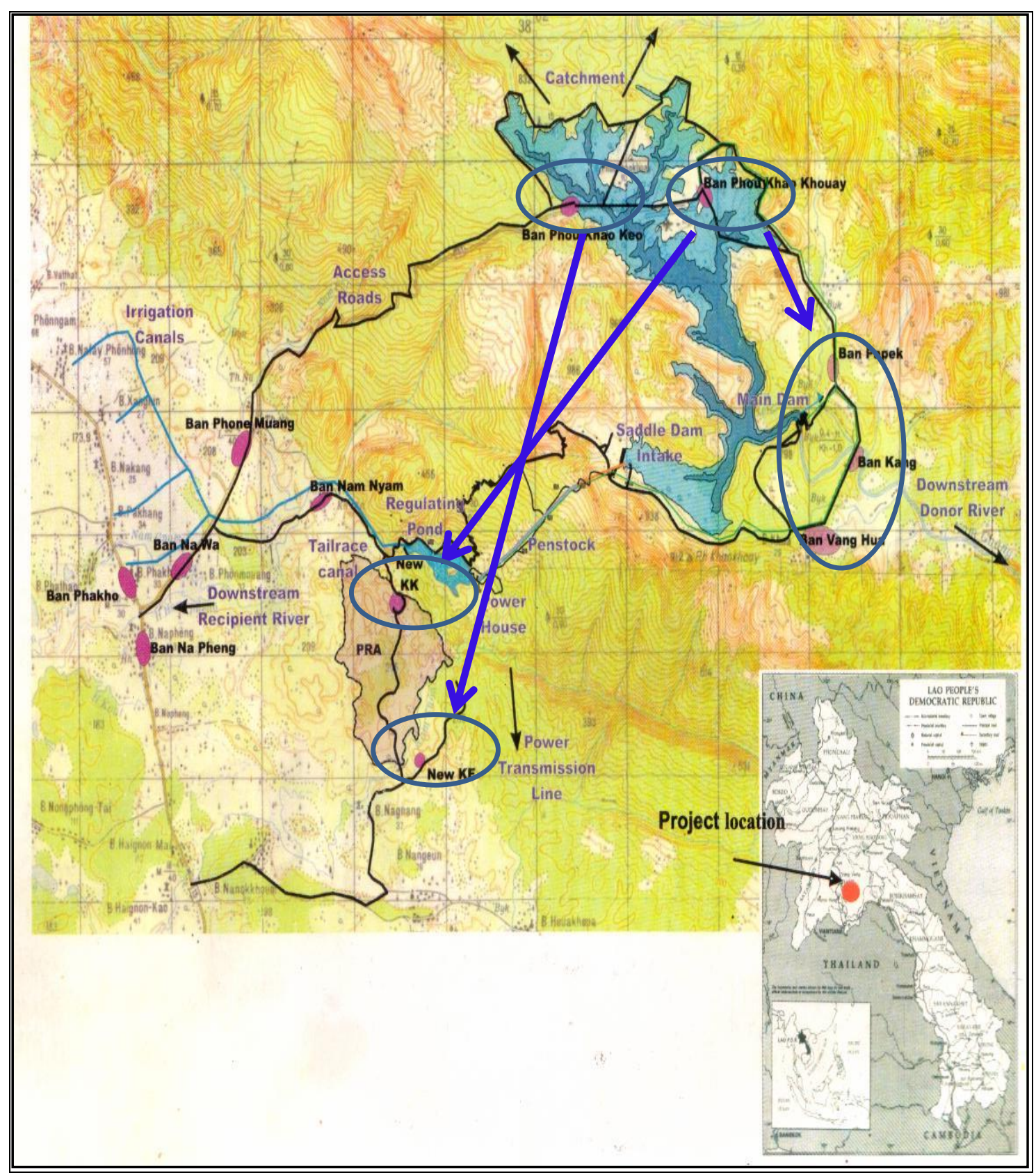

Source: Nam Mang 3 hydropower dam office (2017) 
To compensate for the losses, EDL in collaboration with the Thoulakhoum District Government, established a resettlement committee to undertake the assessment of all non-moveable properties of the people affected in the projected reservoir area. These included paddy lands, fish ponds, fruit trees, houses, irrigation systems, graves and natural fish ponds. However, grazing and shifting cultivation lands were not included in the compensation package (Sayatham \& Suhardiman, 2015). The valuation of property losses was made differently for different types of properties. For example, a house was valued based on the scale, quality and type of materials used. Paddy land was valued against the prevailing agricultural land price at the time (personal communication, July 2017). Based on the assessment and agreement made with the household affected, the loss of the mentioned assets was compensated fully by the EDL with the exception of grazing and shifting cultivation lands.

Apart from the compensation for the losses, it was proposed that the resettled communities would receive 470 ha of non-irrigated land to use as both village and agricultural land. The plan was to provide each resettled household member with 1,600 $\mathrm{m}^{2}$. The more members in a household, the more land they received. In practice, however, the project could not provide sufficient land to all resettled villagers. This is because there was a disagreement between the original land owners and the project resettlement committee, because the 470-hectare land included the preserved land of the host villagers. As a result, some of the households in PKH village did not receive the land they thought they were entitled to receive (Sayatham \& Suhardiman, 2015). In PKK, villagers misunderstood that if they did not take the non-irrigated land offered, the government would allocate irrigated land elsewhere for them. The villagers then decided to refuse to accept the land allocated (Sayatham \& Suhardiman, 2015).

In addition, during the resettlement period the Nam Mang 3 hydropower project provided financial assistance for transporting villagers' materials from old villages to the new locations. Food and health care support to households in three villages for 18 months after the completion of resettlement was also provided. Furthermore, a variety of facilities and infrastructure for the impacted communities include electricity grids, water sources, and access roads, which were constructed by EDL. Other assistance was also provided such as the construction of a new primary school and renovation of the Page | 52 
existing secondary school in Vunghua village as well as construction of new primary schools in the resettled villages (personal communication, July 2017).

\subsection{Key research findings}

\subsubsection{Access to land and natural resources}

Land and natural resources are considered important factors for many rural populations, particularly those whose livelihoods are based on agriculture. In the resettled communities, many villagers are still reliant on farming and natural resources to restore and enable their livelihoods after being resettled. Throughout the interviews, it was found that their farming activities have changed slightly since resettlement. Many families continued farming, but their access to land has changed since resettlement. Before resettlement some villagers farmed on their own paddy land and others practiced shifting cultivation on communal land without paying any rent. For example, a participant said: "in the old village, we cultivated lowland rice of our own and there was no restriction if we wanted to prepare more land for cultivation. But in this village, there is no land to cultivate". However, in the resettlement villages many families rent paddy land from others to cultivate rice while others rent land to practice shifting cultivation. For this change, a female participant explained that:

"my family bought paddy land once we moved here and cultivated it for three years. We then decided to sell the land as it was too far away from this village and bought a new paddy land nearby the village, but still it was not enough for my family as the family became bigger. Again, we sold it and started renting paddy land from lowland people to cultivate ever since".

With these circumstances, a further question was asked to those who did not buy paddy land once they arrived at the resettlement villages. In response, the majority of participants reported that they did not have enough money to buy new paddy land. As one of the female participants explained "once my family moved to this village, we immediately spent the compensation money to build a permanent house and paid for my children's marriage. Therefore, the money left was not sufficient to buy new paddy land" (female participant, July 2017). Some respondents suggested they spent the compensation money for other things while others stated that their compensation 
money was too little to buy new paddy land. They further suggested that it was because the compensation they received for their loss of land before resettlement was too little.

In addition, the number of crops produced also decreased as a result of limited land for production along with less fertilised land at the resettlement areas. Therefore, some villagers had to find places that were further away to farm. As a female participant described:

"in the past we had almost everything. If we wanted something, then we grew and cultivated it. But in here, the good thing is that we have access to electricity and water. However, activities like animal husbandry and the production of a variety of crops have become harder and fewer. Therefore, my children still currently farm and raise animals back in our old village on our own land, which was not flooded by the reservoir" (female participant, July 2017).

This participant depended on two places for livelihood activities, although facilities like water and electricity were better off, land use at the resettlement village was limited.

Apart from agricultural land, natural resources remain important for many families in the resettlement villages both in terms of food and income. These resources include fish, wild animals, forest vegetables, bamboo shoots, rattan shoots, forest herbs, and wood (see figures 5.1 and 5.2). Before relocation, many villagers collected these products for household consumption and sometimes for sale. However, since resettlement accessing many types of these products has become more difficult for the three villages. It has become significantly harder for the two resettled villages since the villagers cannot access land beyond their village zone and they also live far from these resources. As a result of present circumstances there is a slight decrease in access to forest resources according to the interviewed participants in PKH village. While a drastic decrease was experienced in PKK village leading to a number of villagers engaging in non-farming activities, mainly construction and factory work. For example, a participant explained: "land surrounding this village belongs to other people, we cannot even collect firewood on their land". Given this situation, the participant was asked how they were able to make fire given the limited resources. The respondent continued: "we use charcoal and firewood, but sometimes we have to buy it". However, some women were more adept 
at taking advantage of the opportunities posed by resettlement to generate income, for example by selling forest products. According to some of my research participants who said although forest products are harder to access due to the distance required to reach the forest, they perceived it beneficial particularly for those who sell traditional herbs. As a female participant said:

"sometimes it is good to be in this resettlement village because in here there are accessible roads which help me travel easily both in dry and wet seasons. Because of this I can sell traditional herbs in other cities whenever I am free from farming activities. In the dry season I collect traditional herbs in the old village in large quantities and keep it at home in the resettlement village. So, I can sell it for the whole year round without worrying about collecting it in the wet season. In the old village, I can only go to sell traditional herbs in the dry season as it is not easy to travel in the wet season" (female participant, July 2017).

Figure 5.2 Bamboo shoot

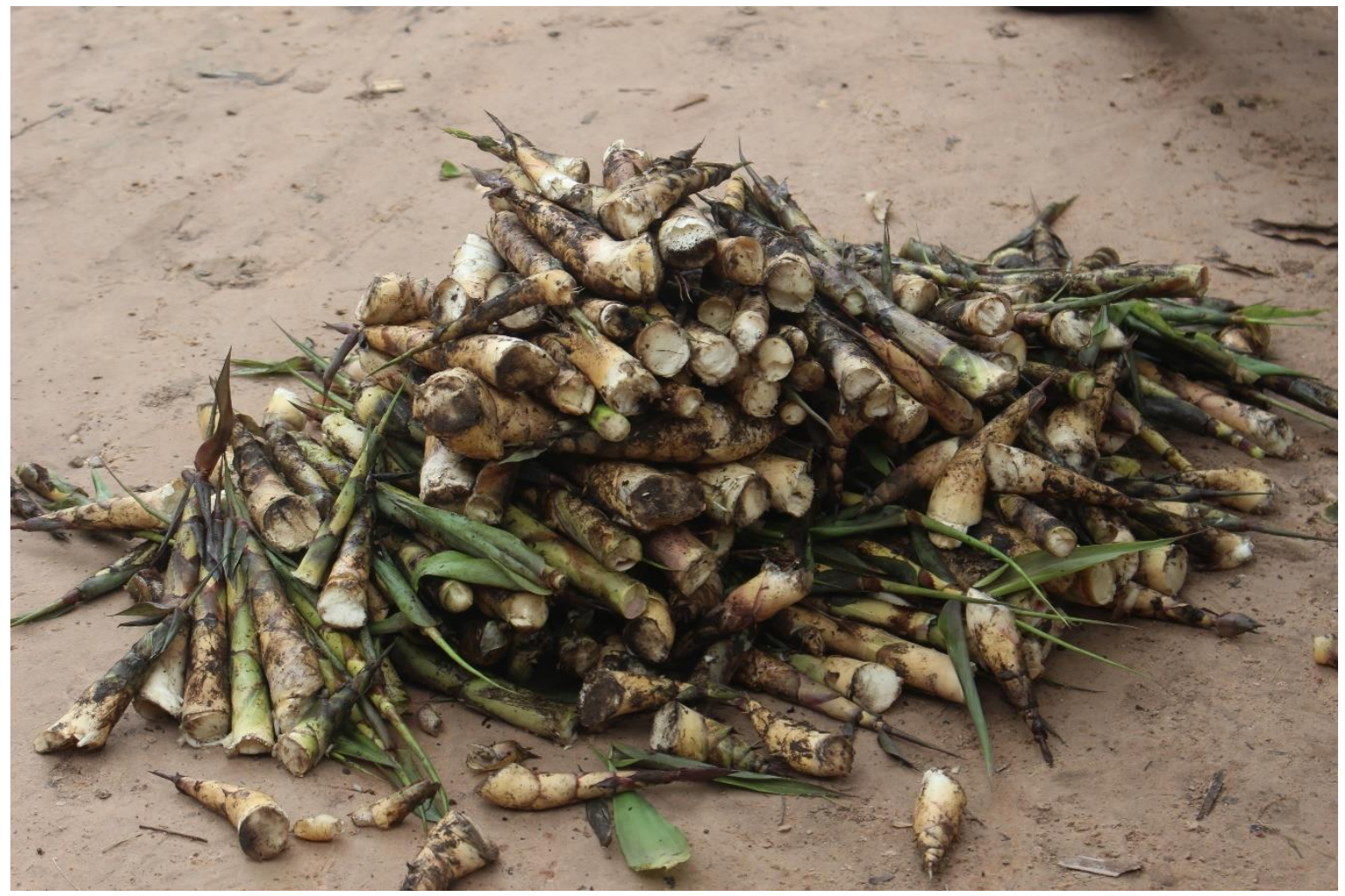

Source: Author (2017) 
Figure 5.3 Forest medicine/traditional herb

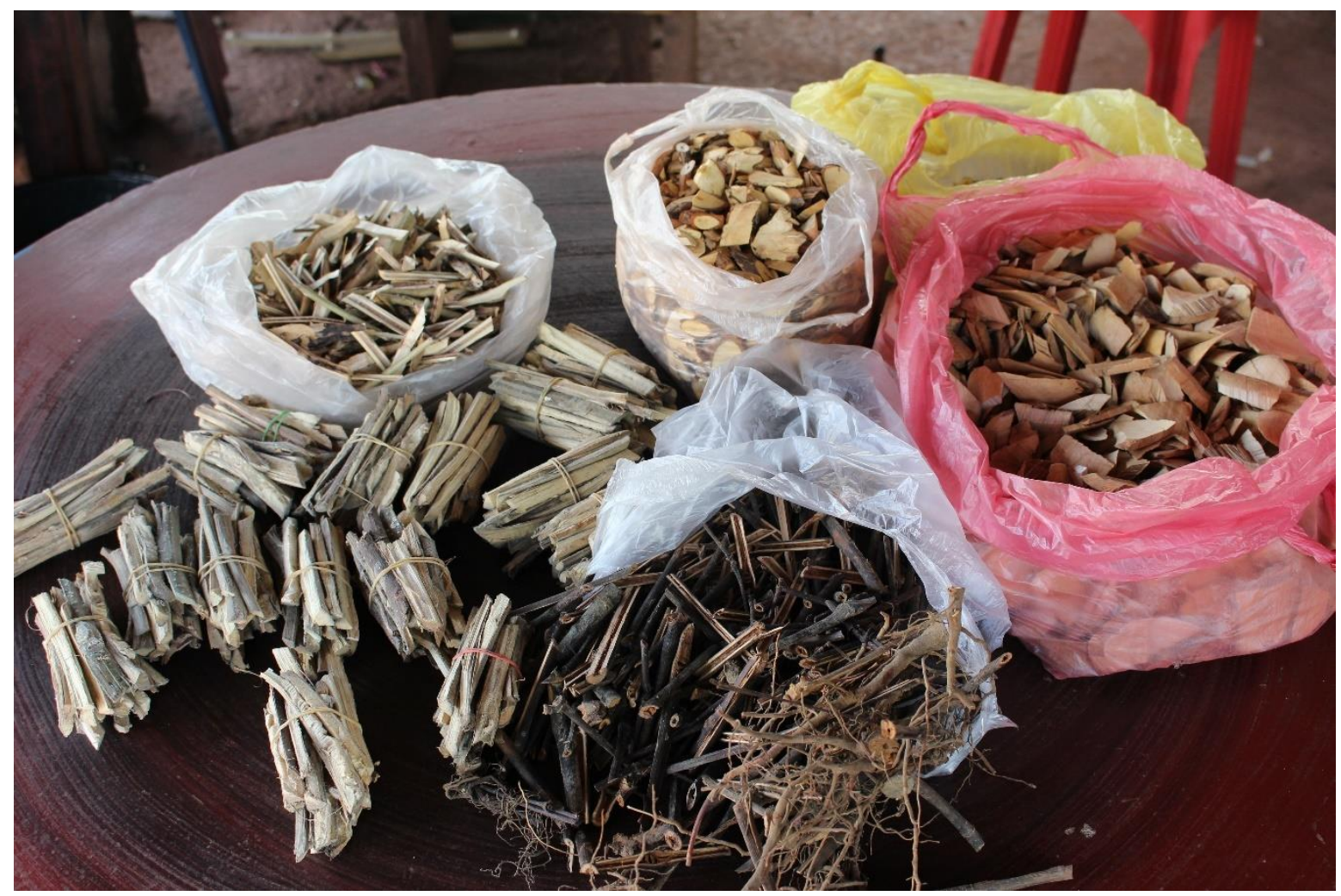

Source: Author (2017)

Before the construction of the dam, villagers including women normally accessed resources in the rivers and a few families engaged in fisheries activities. A participant mentioned that "in the old village, both men and women fished. Men used a hook and net while women used a triangular net to fish". However, since relocation their access to this resource has become difficult due to the long distance from the reservoir. These water resources had previously contributed to many families' food and income. The research findings suggest that villagers are still accessing these resources, but their access is now different among the three communities. Those villagers who were relocated in VH village have greater access to these resources because they are located closer to the reservoir, while villagers in the other two resettled PKH and PKK villages have access difficulties due to distance. Therefore, for some resettled women in PKK village, they now access water resources mainly in the wet season in streams near their resettled village. However, even though the resettled people in VH village have greater access to the reservoir, a major finding was that many women lose their access to this 
resource because of issues regarding distance and safety concerns by fishing in deep water.

Furthermore, resettlement has also led to a change in access to drinking water. In their old village, villagers (particularly women) accessed water from dug wells and streams near the village depending on the season. As an example, one participant stated that:

"in the old village, during the dry season we took a lot of time to collect water due to water shortages. We sometimes had to get up early in the morning and stay late at night to queue for water because of so many people, sometimes it took us hours" (participant, July 2017).

This was a view that was expressed by many participants. In the wet season they collected water from the dug wells in the village, but in the dry season they had to go further away to collect from streams because there was not enough water in the existing dug wells. Therefore, water shortages have created a burden for many women because collecting water created significant amounts of work. Since resettlement the NM3 hydropower project has supported a number of drilled wells in the resettlement villages. This means that resettled villagers have access to sufficient water for use throughout the year. Therefore, this was seen as a positive impact of resettlement, particularly by women who had previously shouldered the burden of water collection.

\subsubsection{Increased women's business and employment opportunities}

Another major finding was the existence of new livelihood activities at the resettlement areas due to the improvements in roads, electricity and water sources. These have benefited the resettled people, particularly women in terms of both agricultural and non-agricultural activities. These include agricultural production, small livestock, weaving, home-based business, and labour for wages. The interviews show that since resettlement there have been many existing shops running as home-based business because of accessible roads and a larger market (see figure 5.3). A female explained that:

"once my family moved here we set up a small shop to sell things, but we stopped after a couple years because there had been many shops in the village and also people in the village like to buy things directly from the market rather than buying from shops in the village" (participant, July 2017). 
This activity was operated mainly by women as they were spending more time taking care of the shop with tasks such as selling and book keeping. However, men also provided help and support in terms of transportation and buying things from markets for the shop. Therefore, being relocated nearer to markets along with better road conditions has provided women with increased opportunities to engage more in productive activities.

Figure 5.4 Home-based shops

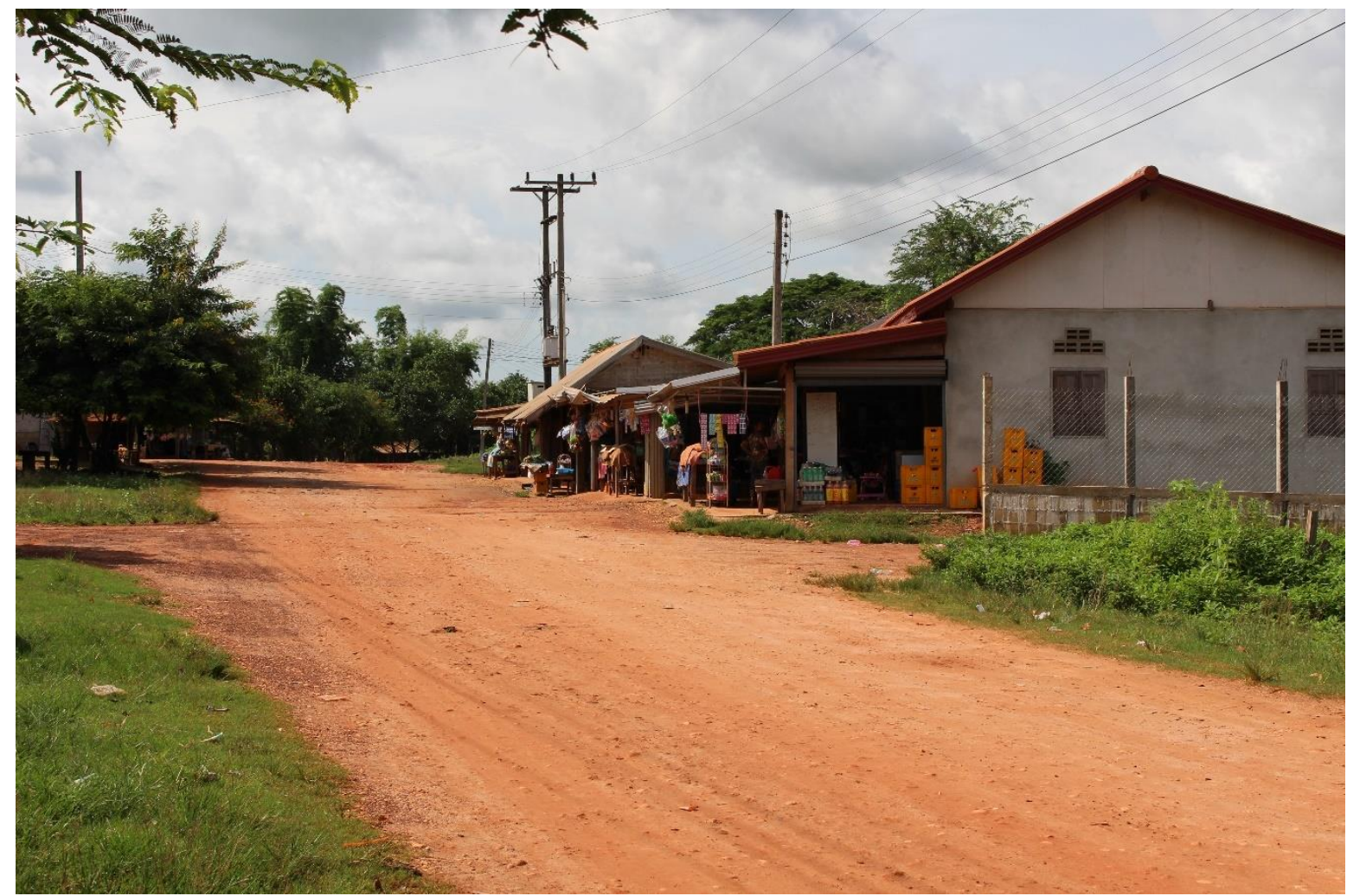

Source: Author (2017)

Before resettlement, their primary daily activities were mainly agriculture which included upland and lowland rice production, and the collection of forest products and other natural resources. These activities were typically conducted by both men and women in a household. However, even though there are still a number of resettled women who continue to engage in the same activities following resettlement many of them are also engaged in secondary jobs as workers in factories; wage labourers in construction; and sellers of traditional herbs. These secondary jobs provide the resettled women with opportunities to generate income for their families. A female participant who has been selling traditional herbs said that: 
"in the old village, I and my husband ran a small home-based business which was a shop. We helped each other, I was responsible more in selling things that were in the shop and my husband came to town with his bicycle to buy things for our shop. At that time, it was very difficult to come to town due to a difficult access road. Therefore, he sometime stayed overnight in town. However, since I and my family moved to this village, we continued this activity for a couple years and then we stopped because of the existence of many shops in the village. I then decided to sell traditional herbs/medicine which I did not do before resettlement. With traditional herbs, I can generate a good income for my family, but I have to travel far, and it takes a long time, usually about 20-23 days each time" (female participant, July 2017).

This is one example of resettlement providing women with business opportunities. Overall, across the interviews resettlement was mainly a positive experience for women as it provided them with increased business opportunities.

However, there were still many women not in a position to access business opportunities. For example, many women could not participate in selling traditional herbs because their husbands and families would not allow them the necessary time away from the household. A participant interviewed, for example, explained that "there were cases where a woman would have to stop engaging in this activity due to conflicts between her and her husband" This was sometimes because the husband was narrowminded". Another restriction was that work in factories, particularly the pig farm that is located about $1 \mathrm{~km}$ from the village, was only available to single women. This opportunity was not possible for married women as workers were required to work and sleep at the workplace. A female participant said that "the company wants only single women to work for them because those who work for them have to stay at the work place for many days" (female participant, July 2017).

\subsubsection{Increased women's dependency}

With resettlement women's dependence on men was noted to increase with less access to land and resources. The situation exists more prominently in PKK village where most men are working and earning wages while women, particularly those who are married, are at home doing subsistence work. A male participant said "mostly women do not go 
with us because they have to take care of the house and children. This is because we have to stay for several nights at the workplace". Thus, the women's total commitment to childcare, household and gardening work has made it hard for them to participate in some money generating activities.

Women's dependency also increased in other activities such as collecting firewood, fishing, and raising large livestock. Since resettlement these activities have become harder to access due to distance and limited opportunities in nearby areas. For example, for many families, except those in PKK village, collecting firewood involved long distances and requires men's labour in terms of transportation. Similarly, fishing in rivers and the reservoir also becomes harder for women because it is too far. Therefore, only men are typically involved in fishing as they can comfortably ride motorbikes over rough terrain and/or in the wet season. At the same time, many resettled families, particularly in PKH village, remain raising their large livestock, especially cattle, in their old village which is one of the most important livelihood activities for many families. As a result it is mostly men who occasionally visit these animals. Before resettlement, these activities were usually conducted by both men and women. Although their dependency on men is greater compared to what it was before resettlement, many women also get involved in many home-based activities that generate some income to support their family such as operating a small shop, growing vegetables, raising poultry, weaving, and collecting forest products (bamboo, mushroom and leaves) for sale.

Overall, with limited land and some resources at the resettlement areas many resettled people increasingly depend on markets to occasionally provide them with food, especially in the wet season. This affects women the most because they used to play an important role in providing food for their families through their own gardening, supplementing this with resources from the forest. A participant explained we "now have a lot of expenses. There is no single day that we do not spend any money" (female participant, July 2017). While there is an increase in dependency due to distance and activities for men, the increase of income from secondary livelihood options such as home-based businesses decreased their workload, as is explained further in the next section. 


\subsubsection{Decreased women's workload}

As a direct result of limited land for agricultural production and livestock raising, many agricultural activities including large livestock raising have decreased and in the meantime livestock like cow and buffalo are now raised further away from the village. One female participant noted as did others that "we now do not have many things to do. After transplanting paddy rice in the wet season, we then stay home most of the time". Overall, resettlement has dramatically decreased women's workloads at home. Therefore, the reduction of agricultural activities as a result of limited land for cultivation leads to fewer activities needing to be carried out daily, meaning that overall women have less activities to do. For instance, at resettlement villages, inhabitants mostly carry out a few agricultural activities such as rice production, vegetable gardening, and raising some chickens, pigs and cows. Prior to resettlement, there were many activities to do every day such as growing many different types of crops like pineapple, banana, sugarcane, cassava, vegetables, maize and rice. For example, a female participant explained that "in the old village we had many farms to grow many different crops, but in this village, we have limited farms to grow crops". In addition, the villagers typically also raised large quantities of small livestock, particularly chickens, pigs and cattle which have always been an important component of their farming activities. These animals were raised in open spaces and with feed from farms and the forest. Many of these activities such as gardening, and small livestock raising heavily required time-consuming women's labour daily. For example, they had to collect animal feed from farms or forest several times a week. Furthermore, with improved water supply and electricity, many women in the new village do not have to travel far to collect water or the task may be undertaken by other family members. This is because collecting water now becomes much easier and safer as the water source is in the form of a drilled well, not a dug well as it was before resettlement (see figure 5.4). Change in agricultural production practices which now involve more machineries such as tractors. Agricultural activities like rice cultivation are commonly carried out using a tractor. 
Figure 5.5 Water source

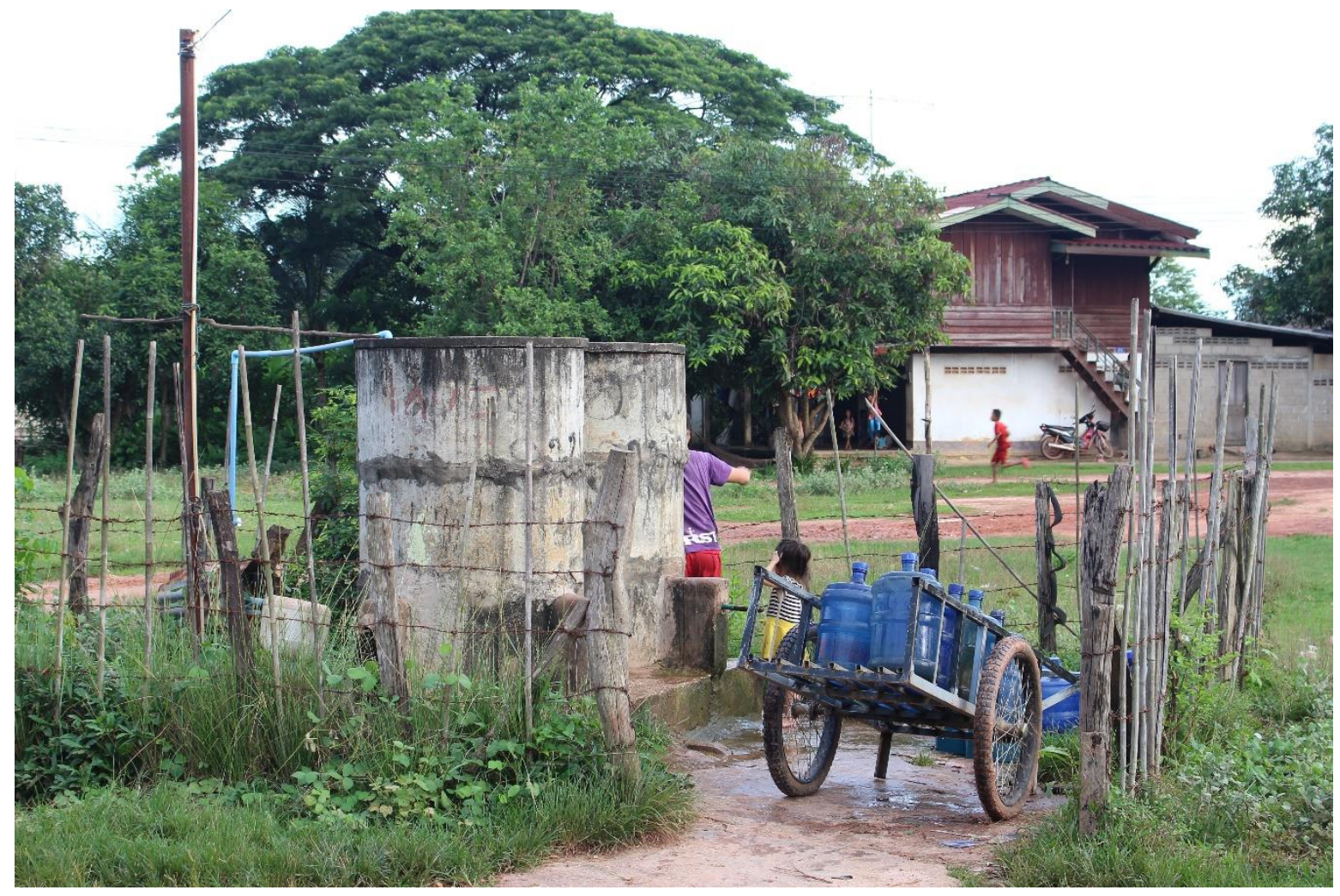

Source: Author (2017)

However, some participants perceived that they had become poorer because they do not have as many things as before. They further explained that in their old village they worked hard and did not have much time to relax, but they had so many things to use and consume and they did not feel worried about food. Furthermore, many villagers said now they can only do gardening in the dry season, while in the wet season they buy vegetables from the market and collect some forest products near the village such as mushrooms and bamboo shoots for consumption and sale. Resettled women were engaged in new activities, but missed their old lifestyle.

\subsubsection{Decline in traditions and agricultural practices}

Following resettlement, the resettled villagers experienced a change in many traditional activities like spiritual activities for those who are ill and cultural celebrations. This exists particularly in PKH and $\mathrm{VH}$ villages as the resettled people in these two villages are Hmong, one of the ethnic groups in Laos. Before relocation, spiritual ceremony or ritual performance was commonly conducted to treat illness. This kind of practice sometimes required the sacrifice of animals like chickens and pigs. Therefore, women in households 
always ensured that such animals were raised to satisfy not only household consumption, but also this kind of ritual activity. For this, a female participant explained that "in our old village we, women, had to raise a lot of animals for our own consumption as well as for cultural activities like spiritual ceremonies, new year celebrations, and for meals when relatives were visiting us". After resettlement, these animals have decreased as a result of the limited areas and feed to raise them. As a male participant added that:

"it was easy to raise chickens in the previous village because there were many different types of feed which could be collected from our own fields like cassava and corn. Sometimes chickens were left roaming around the village to find their own feed. But in this village, there is not so much to feed our chickens on".

At the same time, spiritual treatment for illnesses also declined because many households increasingly began to use other ways to treat illness such as taking medicine from pharmacy shops and/or receiving treatment from the nearby hospital. This was because the resettled people were relocated to new areas where access to hospitals was easier than before. As said by a female participant, for example:

"in the former village when someone fell sick we usually asked a shaman" to perform a ritual treatment first and if the illness still persisted we then took the patient to hospital in town. However, we now mostly apply treatment the other way around".

In addition, following the reduction of land for agricultural production, many families now have fewer opportunities to practice their traditional farming activities. In conversation with elderly villagers of PKH village, one recounted that:

"after resettlement a few households purchased paddy land to cultivate lowland rice while most households rented land to produce both lowland rice and upland rice or shifting cultivation, but now the number of households

\footnotetext{
${ }^{2} \mathrm{~A}$ shaman is someone who is regarded as having access to the spirit world, who enters into a trance state during a ritual, and practices divination and healing.
} 
who own paddy land has increased while the number of households renting land for cultivation has decreased".

This suggests that the resettled women have not only shifted their way of farming from upland to lowland agriculture, but also the way of providing support and help to one another has also changed. Prior to resettlement families, neighbours and friends used to provide help and support to each other through mutual collaboration in paddy and shifting cultivation, weeding, harvesting, and other cultural activities when additional labour was needed. For example, a participant elaborated that:

"in the past it was common to us in the village to provide labour support to each other, sometimes it was in the form of labour exchange, for example, when one family could not finish their farming activities due to a family member falling sick we then collectively contributed labour to help, but now it is not the same".

Such support and assistance from family members, relatives, and neighbours through labour exchange in farming activities provided women with a safety network and reduced women's hardship. This is because women were commonly engaging in this kind of support when they required extra labour for farming activities. However, today many resettled families are experiencing a different way of carrying out their farming activities as they gradually moved from traditions to a more monetised economy. Many of these activities increasingly involved machines and cash. For example, a female participant explained that:

"we now commonly hire labour to do our agricultural work such as transplanting and harvesting paddy rice. Since the paddy field is far from home, it involves many expenses and it takes us longer than if we do it by ourselves. In comparison it is cheaper to hire labour to do it" (female interviewee, July 2017).

\subsubsection{Changing patterns of household and relations}

The relocation of people to new areas also led to changes in household composition patterns and the need for lifestyle adaptation. Before resettlement, families lived in houses near the river and forested areas with poor road conditions which were 
sometimes impassable in the wet season, which reduced communication with people in the city. In the old village, villagers usually lived in extended families and conducted mainly agricultural activities together. Such arrangements were customary and had been in place for generations. This was because young people were usually married within the village or other villages nearby. For example, a participant elaborated that:

"in the old village, young people mostly married someone who lived in the same village or a neighbouring village within 4-5 hours by foot. But now it is common to see people from different provinces getting married to each other".

This change is attributed to the improvement of roading and telecommunications. Even though resettlement has resulted in some family members living far away from their communities of origin, improved utilities like transportation and telecommunication make it easy for family members to keep in touch and visit or help each other when needed. Therefore, some participants stated that they are now more connected to their relatives and family members. As mentioned by a female participant: "since resettlement I have visited my brothers and sisters more often than before my family moved here because it is more convenient to travel by means of transportation". Another female also added that:

"it is now easier to ask for help and support from family without their physical presence. For example, in the past we often provided help in kind or labour to each other, but now if they cannot come they still can provide help by sending cash to hire labour".

In addition, the move from a village to a resettlement site has also meant that the resettled families have had to experience many adjustments in a new environment where they also need to adopt new livelihood activities. This change has implications for different ways the resettled people earn their living and form their relations within the family and community. For example, a participant mentioned that:

"my family members now have many different types of work to do. I sometimes go to sell traditional herbs, my daughter works in town, my son 
works for a company and my partner stays home taking care of the house and young children" (female participant, July 2017).

Consequently, family members are now taking up other activities within and outside of the village to ensure and support the well-being of the family. In addition, in some cases, where women are absent temporary, men also take on the traditional roles of women such as minding young children and conducting domestic chores. Therefore, in the new locations some families have experienced different livelihood options.

\subsubsection{Women's perceptions toward resettlement}

Following resettlement, villagers have benefited from facilities and services that are available within and nearby the resettlement areas, particularly: water, schools, markets, healthcare, roading and telecommunications. One of the research findings suggests that with the improved access to healthcare services villagers feel less worried about their health problems. A sad expression of one of my research participants was that:

"I lost one of my children when we were in our old village. My husband tried to bring the kid to the hospital in town, but because of distance and poor road conditions, my kid passed away not long after arriving at hospital. I think if we had been living in this village at the time, my child would not have died" (female participant, July 2017).

Therefore, with the improvement of healthcare services and roading, villagers can easily access hospitals and receive treatment faster than prior to resettlement, especially when there is an emergency or serious illness. In the meantime, they can also receive advice and information regarding diseases in advance so that they are able to prevent themselves from contracting certain diseases. As told by an interviewee:

"now in our village we have a few young people who graduated from medical school. We always seek help from them whenever we do not feel well, and they sometimes also provide us with information about diseases and suggest how we can prevent ourselves from getting sick, for example, malaria" (female participant, July 2017). 
In addition, in the resettlement areas, both boys and girls can regularly attend school. This is because there is a primary school within the village supported by the hydropower project. At the same time, children can also continue to higher grades in another village nearby as it is easily accessible. With education many females interviewed felt positive about their children's future prospects. As a female participant expressed:

"I support all my children to go to school regardless of gender. My two daughters continued with higher education in the capital city and now they are both working there. They do not have much time to visit home, but they often send us money to hire labour when we start our farming activities" (female participant, July 2017).

As a result, it can be seen that with access to education girls can contribute support to their families. At the same time, they gain broader livelihood options which can help them achieve better living conditions. Again, access to education for children also lessens women's dependency on neighbours whenever they need help. For instance, a female illustrated that:

"in the past it was hard for me to go to town because I did not know the Lao language, so I had to ask others for help. But now I ask my children to help me wherever we want to go, sometimes they also teach me the Lao language".

Therefore, with relocation women particularly the elders slowly adapt and adjust themselves with the new environment by a help from their children who have been educated. By doing so it has helped women gain greater mobility.

In addition, resettlement also brought about a change in attitude toward gender. Throughout my interviews, both male and female participants preferred to have both a son and a daughter. As expressed by a female participant from PKH village:

"in the past once daughters got married, they moved out to live with their husbands. This made it hard for them to help us by contributing labour because they were also busy with their own work. Now daughters can potentially help by providing financial assistance instead of their own labour" (female participant, July 2017). 
Therefore, the change in agricultural practices could be seen as positive for daughters of the resettled families in terms of attitude and roles in families.

Another finding is related to electricity. Access to electricity provides women with greater convenience to conduct domestic activities and support and enhance livelihood activities. Based on my personal observation during the interviews, many women, particularly those who had shops, were spending their evenings preparing vegetables and other products for sale the next day. In addition, having light at night contributed to a sense of security for villagers, specifically women who have to cook after sunset and in the early morning. Furthermore, with appliances such as rice cookers, the use of firewood reduces, which in turn reduces the women's firewood collecting time and their dependency on husbands for this task.

\subsection{Summary}

In summary, following resettlement the resettled population have experienced changes to and impacts on their ways of living, some being specific to women. These changes include the use of land and natural resources; business and employment opportunities; from a traditional to monetised economy; and from extended families to more nuclear families. Overall, there have been a number of different impacts on people being resettled depending on several factors: some positive for women, and some negative. 


\section{Chapter 6 Discussion}

\subsection{Introduction}

The preceding chapter highlighted the main findings in relation to the impacts of resettlement on women following the construction of the Nam Mang 3 hydropower project. This chapter will discuss key findings that have emerged from the research fieldwork linking to existing research and previous studies around hydropower resettlement. The aim of this chapter is to provide a deep analysis of how resettlement of the NM3 hydropower dam affects women in terms of their livelihoods, their relationships with their community, and their aspirations. The chapter is organised around the key themes that emerged from the analysis, namely, access to resources, access to new livelihood opportunities, change in agricultural practices, and change in social support.

\subsection{Change in agricultural practices}

One of the major findings of this research suggests that the resettled people experienced new and different forms of agricultural production. Before resettlement, villagers practiced subsistence agriculture where upland and lowland rice production were the main agricultural activities, with livestock, gardening and natural resources supplementing these. Many of these activities were jointly conducted by both men and women. In addition, women also exchanged labour when extra labour was needed and sometimes they even provided labour support for others for agricultural production particularly in activities like planting rice, weeding and harvesting. However, once resettlement took place, some of these agricultural activities were diminishing particularly gardening, shifting cultivation, and also traditional ways of providing mutual support like labour exchange. At the new locations activities like transplanting and harvesting paddy rice, and vegetable gardening now require hired labour and new farming equipment.

On the other hand, the shift of agricultural practices has increased the amount of time women have for other activities and therefore their engagement in other economic 
pursuits. Relocating closer to cities means that the resettled households have greater access to other resources and facilities including electricity, roads, and transport. With the assistance of modern facilities many women were not only found to have more time at home, but also their engagement in many different income-generating activities both inside and outside their communities increased. The application of new farming equipment also resulted in less time being spent on agricultural activities which previously took women a lot of time. For example, the use of tractors in time-consuming and heavy agricultural work such as ploughing, harvesting, and transporting also has played a crucial role in reducing women's labour. This has meant that women had more time available for other economic activities. For example, this research highlighted that resettled women were able to leave home for many days on end to earn cash.

In addition, the change in farming practices have brought about other positive impacts on the resettled families, particularly girls. In rural areas where subsistence agriculture is primarily important for households, girls are culturally responsible for household chores and caregiving of younger siblings (Peters, 1998). Therefore, the shift in agricultural production practices from resettlement described above could result in an increasing number of girls in education, though there was no clear evidence of the time of research.

\subsection{Access to resources and forestry}

Through the interviews and the analysis, the findings of this research suggest that land for agricultural production, including for raising livestock and shifting cultivation, was limited in the two resettled villages, PKH and PKK. However, even though the resettled people have limited land for agriculture in the new locations, many of them continued to practice their previous agricultural activities, such as raising livestock, cultivating lowland rice production, practicing shifting cultivation, and gardening.

This change affected the division of labour among members in a household. With limited land at the resettlement sites, many households did not have many options but to leave their large livestock, cattle and buffalo, grazing in their original areas in their old village far from the resettlement areas. Because of the distance to these sites, the visits to and care of these animals have fallen to men and it now takes much longer per visit than before relocation. At the same time, women who used to help their husbands in this 
activity now have to depend on their husbands to do this work, and overall, they are less involved in livestock rearing. Livestock rearing, then, has become more differentiated by gender and has declined as a contributor to household livelihoods.

With relocation, the number of livestock of the resettled households has declined. As a result of limited availability of grazing areas at the resettlement villages, livestock are now grazed further away from the resettlement village meaning that the visit could not be made frequently. Therefore, this has resulted not only in a reduction of animals raised for many households due to diseases and theft, but has also caused some households to stop raising large livestock completely. Such circumstances have affected the resettled women, who in the past reared smaller livestock at home, but now partly depend on markets to buy meat for consumption. In addition, due to livestock being an important source of income, the decline has tended to reduce their income. This was also evidenced in a previous study by Sayatham (2013) that found that the income of the resettled households particularly in Phoukhaokhouay (PKH) and Phoukhaokheo (PKK) villages from livestock declined due to the reduction of their livestock. In addition, another case study conducted in a neighbouring country, Vietnam, also found a reduction of farm animals after relocation due to the construction of a dam because land and fodder for livestock at the resettlement sites were limited (Bui \& Schreinemachers, 2011).

For rural households, subsistence agriculture plays a significant role. Such agricultural practices include production of a variety of crops and livestock. Crops are grown all year round to provide food while livestock is raised for consumption, cultural activities, and income. Besides crop production, livestock is one of the most important livelihood activities. According to Stür, Gray, and Bastin (2002), in many rural areas where road conditions are poor livestock can become an even more important source of income than other agricultural practices. This is because cattle and buffalo can be easily brought to markets for sale as they can be walked to the market, while other agricultural products require transportation. In addition to food and cash, rural villagers also keep livestock as a means of capital or wealth accumulation which can be utilised to meet other household such as healthcare and education (Stür et al., 2002). For instance, a villager interviewed explained that "even though my family moved to this village, we still keep our cattle in the previous village. So that we can sell it when we need money". 
Women in Laos typically share a substantial role in livestock rearing, particularly chickens and pigs. Their contribution includes the collection and preparation of feed like banana stems, maize, cassava and vegetation from farms and forests (Stür et al., 2002). This was illustrated by a survey conducted in 5 Northern provinces of Laos, for example, where more than 50 percent of activities (like collection of feed, cooking feed, and feeding the pigs) was mainly conducted by women and children, whereas 38 percent was done by all family members, and less than 5 percent was implemented by men. The survey further suggested that the figure is even higher for ethnic groups living in rural areas particularly Mon-Khmer, Hmong-Mien, and Tibeto-Burman groups, respectively (Phengsavanh, Ogle, Stür, Frankow-Lindberg, \& Lindberg, 2010). Therefore, the reduction of this activity at the resettlement villages affected women the most as they previously played vital roles in providing food and earning income through livestock raising activities.

Apart from livestock, this research further highlighted that access to natural resources of the resettled people has become harder due to distance and limited availability at the resettlement areas. Collection of many forest products was abandoned as it was not available at the resettlement sites. However, some natural resources remain essential and accessible for further sale and household consumption. These resources include bamboo shoots, mushrooms, leaves, traditional herbs and water. For example, a study conducted on production and market engagement of the Hmong and Lao Loum communities resettled from the Nam Mang 3 hydropower dam showed that forest resources remain an important source of income for a number of resettled households. The income of the resettled people derived from forest products such as bamboo and traditional herbs increased substantially after resettlement (Dalasavong, Southiseng, \& Walsh, 2015). This was due to improved road access and markets where these forest products could be sold to traders coming to the villages and/or easily transported to nearby markets.

Non-timber forest products (NTFPs) are an important source of food as well as income for villagers. According to Rigg (2006), in Laos many food items can be found and taken from forests by villagers. These include bamboo shoots, traditional herbs, rattan, firewood and fibres. It has been estimated that the typical rural Lao family consumes about US\$280 of NTFPs on average per year, which is about 40 percent of total rural 
family income (Rigg, 2006). Typically, in more remote hilly areas, 40 to 60 percent of household income is from the sale of NTFPs and it is even up to 80 percent in some cases (UNDP, 2002, as cited in Rigg, 2006). Income from NTFPs is particularly important for households who are not rice secure (ibid).

The findings of my research highlight that the relocation of people from a village to a new location can affect the ways women earn their living and support their families. Previously the resettled women were efficient in subsistence agriculture and collection of forest products for food and income. However, following resettlement, limited access to land and natural resources affected the resettled women by reducing their ability to support their families in familiar ways. Their important role as food provider will also not be recognised if other alternative sources are not available.

\subsection{Access to new livelihood opportunities}

Following the change in access to land and natural resources, findings from the research further suggest that many resettled women have adopted new livelihood activities within and outside the resettlement villages. These include running small shops; working for private companies; selling traditional herbs; as well as wage labouring. These nonfarming activities were made possible through the existence of basic facilities and infrastructure particularly roads, electricity, water, and markets. These amenities, therefore, play an important role in bringing not only opportunities to the resettled communities, but also strengthening women's financial contributions to their families.

Increasing participation of women in income generating activities, both inside and outside the home, has a positive impact on the share of household responsibilities. Men were found to take increasing responsibility for housework and childcare while women were away earning an income. In addition, with income earned, women gain a position where they can make some decisions regarding expenses. They tend to spend money for the wellbeing of their family. For example, a woman interviewed noted that: "once I got money from the sale of crops and forest products I gave some to my children to go to school and spent some to buy things for my household. Then the rest was saved". Increasing women's engagement in economic activities also aligns with the $8^{\text {th }}$ Five-Year National Socio-Economic Development Plan of Laos as one its focuses is to ensure women's equal rights and development in economics (MPI \& UNDP, 2016). In addition, 
it is also to bring stable employment to women so that they can generate income (ibid). Therefore, the resettlement scheme supports the achievement of the Plan as women have directly benefited from new livelihood opportunities. As suggested by Standing and Bandyopadhyaya (1985), women belonging to different socioeconomic classes may experience disadvantages in relation to men of their respective class; but not all women are absolutely disadvantaged in terms of their access to a basic minimum livelihood. In certain situations, it depends on the nature of the project and implementation process as well as the socio-political environment of the area, as to whether women can remain in a similar economic position.

\subsection{Social structure and support}

Resettlement can result in eroding social support networks. For instance, a case study conducted by Asthana (2012) showed that social support was disturbed by the process of displacement. Such social networks were an important source of support for poor families, particularly in times of need for labour and loans. In addition, the same study illustrated that many agricultural tasks that had been jointly implemented by both men and women were performed through hired labourers at the resettlement areas (ibid). In addition, women were marginalised and disempowered in the resettlement villages since tasks like negotiation for hiring labour and supervising agricultural activities were mostly conducted by men. Moreover, women also lost their space to interact with others and sometimes experienced fear based on the unfamiliarity of leaving their village. Therefore, this caused women to feel depressed, stressed, and sometimes lonely (ibid). However, the findings of this research did not align with this study by Asthana (2012) and findings of other literature as presented in Chapter two regarding social networks and support. For example, the present research suggested that after resettlement the resettled households remained located near their relatives as they were previously, so that they were still able to provide support and assistance to one another. As explained by a research participant: "once we moved to this village, residential land was provided, and we were allowed to make an arrangement of our own communities. Here we are still surrounded by relatives". Even though the resettled women lost their traditional social support network, they adopted new ways of providing and receiving support. For example, the findings of the current research 
suggest that many daughters and sons who worked in town supported their parents by sending them money to hire labour. Another example was related to support provided in caring for livestock. A participant noted that: "since our livestock is still there in our old village, sometimes we asked our relatives who live near our old village to help us look after it". Another finding from this research also indicated that, following resettlement, women themselves also formed their own social support network. As indicated in the interviews, women who sell traditional herbs mostly go in a group of two or three. The same happened when they collect traditional herbs from forests as explained by a participant: "sometimes when I was busy and cannot go to collect traditional herbs in the old village I usually call my relatives who remained near the old village to collect it for me. Sometimes I asked them to accompany me to the forest to collect it". Therefore, by getting the resettled population involve in the process of resettlement helps minimise the issue related to the loss of social support networks of the resettled communities. This is because the resettled people know where they should locate According to the conversation with the elderly villagers, one explained that: "before we moved here we were asked to visit many different places where we wanted to be relocated, then we decided to locate to this area as it was close to our old village".

\subsection{Women's perceptions of resettlement}

This research noted that after resettlement the resettled communities were provided with support and assistance by the NM3 hydropower project. This included electricity, water sources, and an access road. All households were connected with electricity, and the water source was sufficient for a whole year. At the same time, access roads were made passible in both dry and wet seasons. In addition, other services like healthcare and education were easy for the resettled communities to access. These were viewed by women as positive aspects of resettlement.

Following resettlement, the resettled women experienced changes in lifestyle from subsistence agriculture to a marketised economy. This change brought about many adjustments for women. Many resettled women had to adopt and participate in new livelihood activities to earn income, including small shops, wage labouring, employment, and petty trade. By virtue of this change, women experience increases in mobility and have access to services and facilities that can help improve their living conditions. 
Furthermore, engagement of women in home-based business like small shops requires less physical conditions, which allows women to spend more time at home to look after children. The responsibility for domestic care is consistent with women's important reproductive role, as highlighted in the GAD framework.

In the new locations, the resettled women emphasised the need for education for their children. With education their children could achieve greater livelihood options. This was due to the following reasons: (i) production assets, particularly land, were limited and decreased due to an increasing number of family members; (ii) farming activities involve hard work; and (iii) new livelihood options at the resettlement that require more skills and knowledge. Therefore, many resettled women saw that if their children could take the livelihood opportunities at the resettlement villages their lives could possibly be improved and better off compared to the previous ways of earning a living. This was confirmed through some ethnic women having chosen to relocate from remote areas to locations where better roads and markets were accessible. By doing so, they became more efficient at performing a number of tasks which would help enhance their economic mobility (Inui, 2015).

Therefore, relocation to lowland areas where amenities are accessible resulted not only in increased livelihood opportunities, but also the wellbeing of the women themselves as well as their children. Given that "education is one of the most important means of empowering women with the knowledge, skills and self-confidence necessary to participate fully in the development process" (as cited in Miki Inui, 2015), resettlement can bring women, particularly girls, greater opportunities to achieve this. This was confirmed by a World Bank study in Laos, which showed that about 40 percent of children who drop out of school do so because higher grades are not available in the area where they live. In addition, safety issues are also a concern for many parents who decide not to enrol their children in school (Patrinos, Danchev, Cerdan-Infantes, Marshall, \& Naka, 2016).

\subsection{Summary}

Resettlement resulted in a number of changes to the lives of women. Their livelihoods have changed from subsistence agriculture, in which women had great responsibilities to ensure food security and income in a family through farming and natural resources, 
to a monetised economy where women had to adopt new kind of livelihoods. With the nature of new livelihood activities women achieved greater mobility and income earning opportunities. In addition, with improved facilities and transport women experienced improved connections with family members as well as their engagement in income earning activities. Furthermore, women saw resettlement as an opportunity to achieve better living conditions with an emphasis on education for their children. 
Page | 78 


\section{Chapter 7 Conclusion}

\subsection{Introduction}

The primary objective of this research was to explore the impacts of hydropower resettlement on women. The aim was to provide a better understanding of the impact of resettlement on livelihoods, women's relationships, and women's aspirations following resettlement from the Nam Mang 3 hydropower project in Laos.

To obtain a deep understand of issues around resettlement on women, the research adopted and followed an approach which included social constructivism; a Gender and Development (GAD) framework; qualitative methodology and a semi-structured research technique. Through this approach, the research was able to explore the issues through the voice of people at the local level, as well as from women. The research also provided a picture of how the process of resettlement affected women in terms of their livelihoods and their relationships within their household and the community. In addition, the research was also able to explore women's views regarding resettlement and changes to their aspirations as a result of relocation.

This concluding chapter will first summarise the research findings and key discussion points. It will then provide recommendations and discuss the limitations of the research. The chapter will end with suggestions for future research.

\subsection{Summary of research findings}

For around ten years since the communities were relocated in 2004 to give way for the Nam Mang 3 hydropower dam, many changes have taken place in the lives of the resettled people. Based on the interviews, following resettlement, land for agricultural production, particularly land for livestock, was limited at the resettlement areas. The access to reduced land not only resulted in a decline in livestock, but also the variety of crops. Overall, women's involvement in agricultural activities decreased. Even though the resettled people in the two resettled villages remained dependent on paddy land, shifting cultivation, and forest products, their dependence on markets for food also increased. 
The research also found that since resettlement a number of women have taken the opportunity to engage in many different types of work at the resettlement areas to earn an income. With these opportunities, women were able to generate better income from their engagement in activities like small scale trade, selling traditional medicine and other forest products, and wage work. These opportunities were possible due to the availability of facilities and services such as access roads, electricity, water, and markets. Therefore, by adopting and engaging in new livelihood options, the income earning opportunities of many resettled women improved. The research findings tend to agree with the GAD framework in that women's status in society is deeply affected by their material conditions of life and their position in the national, regional, and global economies. With access to opportunities to earn material conditions, women's status within the household likely increased even though it was not directly evidenced from this research.

However, this research also suggested that there were women, particularly those who were married, who could not harvest significant benefits from the opportunities available at the resettlement areas. These women were excluded from the economic activities due to the particular nature of the new livelihood options and a lack of the financial resources to start economic activities. Therefore, these circumstances increased women's dependence on their husbands financially. This finding agrees with much GAD literature that women's material conditions are defined by the accepted norms and values that define women's and men's roles and duties in a particular society. In addition, access to a variety of forest resources was limited at the resettlement villages. Previously, villagers were heavily dependent on nature to provide them with food and income and women played significant roles in collecting forest products in a household. The limited access therefore affected the role of women as a provider of food through the collection of forest products. However, even though there were fewer forest products available at the resettlement areas, many women gained opportunities to increase their income by collecting and selling forest products like bamboo shoots and traditional herbs. These opportunities were due to their easy access to markets and with the assistance of transport. 
Furthermore, following the dam construction, the number of facilities and services were improved and made more accessible for the resettled households. These included road access, electricity, water, healthcare services, and education. This improvement has brought women new livelihood opportunities that helped enhance their income earning opportunities and at the same time it broadened their social connection with outsiders. Women's worries and stress about health issues also declined due to better access to health care services, facilities, and easy access to information regarding health issues. In addition, relocation near to town also provided girls with increased opportunities for education and employment in town and other areas. Education for children was perceived as necessary and essential in the new locations because through education young people could broaden their livelihood options - for example, working as wage employees or operating a business. With education young girls would not need to work hard on farms, which was typically viewed by all research participants as a less ideal existence.

The research agreed with the gender and development framework that the government has an important role to play in supporting women by providing social support in areas of healthcare, training and education. Such support, particularly healthcare and training, is crucial for the improvement of women's health and capacities in the short-term. In the long-term future generations of women will benefit from development through education.

\subsection{Key research questions}

One of the principle aims of this research was to explore the impact of resettlement on livelihoods of the resettled women.

\section{How have women's livelihoods changed since resettlement?}

Following resettlement, resettled households still depended on agriculture for their primary livelihood activities, but supplemented this with natural resources and other new livelihood options. However, some agricultural activities such as the cultivation of crops have decreased. Similarly, livestock rearing, which is one of the most important livelihood activities, also been affected as land for livestock was limited in the new locations. In contrast, more intensive lowland rice 
production has become increasingly important for resettled households after resettlement given that the new locations are close to a city with better road access, many new livelihood activities were introduced to both resettled men and women. In addition, the provision of electricity, water, and new farming equipment has helped reduce labour in water fetching and agricultural work. As a result, the time saved has enabled a number of women at the resettlement villages to engage in income earning activities such as running home-based businesses; selling forest products; and working in private companies. Their engagement in these activities, therefore, increased not only their mobility, but also enhanced their ability to provide support to meet their household needs including education for their children. For most participants resettlement created largely positive outcomes.

However, there were still women who were not be able to sieze the opportunities. These women remained reliant on agriculture for their livelihoods, and were negatively affected as land for agriculture was limited at the resettlement areas. These women remained at home taking care of children, doing household activities, and occasionally collecting forest products nearby the village and waiting for their husbands to bring home income.

How have women's relationships with their community changed since resettlement?

The research found that women's traditional social support networks have slightly changed. This was due to new livelihood activities, particularly agricultural activities, being introduced in the resettlement areas. The introduction of new farming equipment like tractors and threshers in agriculture also played an important role in the decline of traditional labour exchange. With tractors and other farming equipment, many activities did not require so much labour to do farming activities. Therefore, women had more time to be at home and do other things such as weaving; collecting forest products for sale; and visiting friends and family. The decline in labour exchange was also supplemented by the adoption of a new lifestyle in the new locations where cash has increasingly becoming a means of exchange. However, in the context of this resettlement, social support 
remained strong. Almost all the research participants suggested that they had become more connected to their family members and relatives. Their visits to other family members were more frequent than in the previous villages given the better roads, transport facilities and communication. Another reason was because the resettled people were moved in groups and located in one location where they were able to remain together. Even though labour exchange rarely existed in the relocation areas, support and assistance from family members and relatives remained, but mostly in the form of monetary terms.

How have women's aspirations changed after they were relocated to new locations?

Following resettlement, many women felt happy about their lives in the new locations. Due to the improvement of facilities like roads, water, and electricity, many different types of work were adopted and engaged in by the resettled communities. Women were also increasingly involved in these new livelihood activities. However, even though a number of women enjoyed the opportunities at the resettlement areas by actively participating in new livelihood activities, they experienced or adopted different ways of conducting those new livelihoods. Therefore, as they have been able to access many facilities and services. Their houses have been permanently constructed so that they do not have to worry about preparing new materials to rebuild every two or three years. Overall, there are largely positive findings, though benefits are uneven. This goes against much of the established literature on dams and resettlement which are mostly negative. For example, studies of Bisht (2009); Lahiri-Dutt (2012); Mehta \& Srinivasan (2000); and Yong Ooi Lin (2001). Perhaps lessons have been learned and more careful resettlement strategies have been implemented. But still much can be improved, especially in relation to the benefits for both women and men.

\subsection{Key recommendations}

From the findings of this research and what has been discussed above, this research suggests the following recommendations. 
(i) Resettlement plans should be carefully designed so that access to land and other resources can be maintained. By doing so, in both the short and long run, land use should be considered the most important aspect to meet an identified urgent need. It is particularly important for the landless households to have enough appropriate land and techniques to carry out their cultivation and a commitment that the use of land is permanent to ensure the success of certain livelihood activities. This will also help the more vulnerable groups of people, (for example, those who received less compensation cash and could not purchase new paddy land, women-headed households, and the poorest of the poor who have no alternative jobs) and these should be paid special attention to in order to reduce the disparity of cost and benefits from the dam construction.

(ii) Alternative livelihood options should be assessed based on the local socioeconomic context as well as through a gender lens. Proper surveying and consultation regarding potential strengths and constraining factors should be gender-inclusive. This is because it is crucial to re-establish different livelihood assets and increase local capacities to access resources and opportunities available at the resettlement areas. The capability of and accessibility to these resources are essential to the reconstruction of the resettled communities and to the achievement of their own livelihood goals and objectives in the future. Most importantly, based on this research finding, resettled women were found to play significant roles in supporting their families through various income earning activities. Therefore, the more active and meaningful participation of both men and women must be encouraged throughout the process of resettlement and livelihood strategy development.

(iii) The resettled people, particularly the resettled women, should be involved throughout the process of resettlement. By doing so, the needs and issues of all people affected could be better identified. This is to ensure that the resettled people are informed about alternative options and possible impacts of the project, and they are given opportunities to be involved in key decisions that would affect their lives. Women should be counted on in the process as their contribution to their family's wellbeing was significant. If these aspects are taken into consideration, future resettlement and livelihood reconstruction initiatives will likely be more inclusively successful and bring more positive results and outcomes to not only women themselves but also their family. 
(iv) Monitoring and evaluation should be conducted in a gender-sensitive or participatory approach after resettlement has taken place. Monitoring helps identify the potential and needs of the resettled population in relation to restoration of livelihoods and improvement of living conditions. This is because through relocation some groups of people may adapt well to new livelihood activities at the new environment while others may find it hard. Therefore, with monitoring and evaluation, lessons can be learnt, and changes can be made so that negative impacts on the resettled population for both men and women can be minimised in the short-term as well as in the long-term. By doing so future dam construction projects can better anticipate effective programmes of resettlement.

\subsection{Limitations of the research}

This research did have some constraints and limitations. One of these was that the amount of literature in the field of gender, particularly in the context of Laos, remains small, including resettlement. This is partly due to the experience of hydropower development in Laos being relatively new. In addition, access to sources of information was also limited - for example research and studies around women's empowerment in Laos. The research was also limited by time: only one resettlement programme was able to be studied and involved 18 interviewees from three affected villages. With a longer timeframe, research could include more interviews and undertake comparitive studies of other resettlement programmes. At the same time, with the strict timeframe in the field, the researcher was not able to spend much time observing and having conversations with local people in more relaxed settings for greater clarification and deeper appreciation of the topics discussed.

\subsection{Recommendations for future research}

Through this research, there were a few areas that can be recommended for future exploration. Firstly, future studies could focus their exploration on more specific groups of women and their coping strategies. The current study explored the impacts of resettlement of women from a wide range of social and economic backgrounds, so that the exploration was not limited to only one or two particular types or segments of women. For example, this could examine women from more affluent households and 
women from less affluent households; or a group of women with new livelihood options and those without. This is because it is problematic to group all women into one homogenous category. Within the female population individuals may have different experiences depending on their class and ethnicity (Thukral, 1996). Therefore, future studies on a more specific group of women could be valuable. By doing so it could provide an opportunity to deeply understand the impacts of resettlement on different segments of the resettled communities. Experience from the most vulnerable groups could be explored and understood so their issues could be sensitively counted and effectively addressed.

Secondly, future studies could apply both quantitative and qualitative approaches. For instance, prior to resettlement women's contribution in a household tended to be more in kind, while in new locations it is more about monetary terms. Therefore, the impacts should be studied and explored through both qualitative and quantitative approaches exploring both social and economic impacts can be covered.

\subsection{Research summary and closing remarks}

The purpose of this research was to explore the potential impact of the resettlement programme on the resettled women associated with the Nam Mang 3 hydropower dam project in Laos. In the following section, I will summarize the key results along with some closing remarks.

Firstly, the Nam Mang 3 resettlement programme has had a number of positive impacts on the resettled women. Their access to different, new livelihood activities has increased and their financial contribution to the household income has become significant. With resettlement, the resettled population, including women, have been experiencing improved physical assets such as permanent housing, access roads, electricity, better transportation, sufficient water sources, and agricultural equipment. Such improvements at the resettlement areas have had an impact on women in a number of positive ways such as the reduction of women's workloads, and increased opportunities for other economic and productive activities.

Secondly, the Nam Mang 3 resettlement programme created significant opportunities for the people to obtain a number of social benefits. This research highlighted improved 
accessibility of women and children to better health and education services. Another positive advantage is that it has helped people to be in closer proximity to other members of their family and relatives. This connection has been enabled by the availability of transport and telecommunications in the vicinity of the urban areas. It is a fact that relocated people have limited land to cultivate. However, this study has shown that some resettled people were able to devise alternative income-earning activities that were home-based to support their lives. In terms of health, resettlement brought people closer to health facilities, which is beneficial in terms of travel time in cases of emergencies.

As discussed in Chapter three, Laos is rich in natural resources and endowed with rivers. Laos has a potential hydropower production of 26,000 megawatt (MW). However, until 2013 only around 3,230 MW of installed capacity or about 12.4 percent of the total potential has been produced. Since hydropower is currently one of the essential driving factors of economic and social development, and also in the future for Laos, it appears inevitable that this energy source will continue to grow to produce near its maximum potential. As a result, there is a high possibility that more and more people will be displaced and resettled. As can be inferred from this research, the impacts of resettlement should be taken into consideration in hydropower dam planning and development. The government and the hydropower developers need to learn from the previous experiences of resettled peoples and continue to develop sound resettlement policies, plans and strategies to address the impact of displacement and resettlement in a more gender-inclusive and sustainable manner. In the past, women's needs in the NM3 hydropower scheme were not consistently considered in the process of resettlement. Although not all women were positively affected by resettlement, the result of the study has shown that most women reported some benefits from the resettlement. Hence, the lessons that can be learnt from the NM3 hydropower dam scheme is to involve women in the process of future resettlement so that they can raise their awareness and express their needs for effective planning. Women understand best which conditions are suitable to them and would enable them to adapt smoothly to resettlement. To ensure all women benefit from resettlement, there is a need to establish an appropriate monitoring system and rigorous process to ensure the benefits do occur for all women regardless of social and economic status. 
Page | 88 


\section{References}

Agarwal, B. (1995). A field of one's own: Gender and land rights in South Asia. Cambridge: Cambridge University Press.

Altinbilek, D. (2002). The role of dams in development. International Journal of Water Resources Development, 18(1), 9-24.

doi:https://doi.org/10.1080/07900620220121620

Asian Development Bank. (1995). Policy on involuntary resettlement. Retrieved from https://www.adb.org/sites/default/files/institutionaldocument/32515/files/involuntary-resettlement.pdf

Asian Development Bank, \& World Bank. (2012). Country gender assessment for Lao PDR-reducing vulnerability and increasing opportunity. Retrieved from https://openknowledge.worldbank.org/bitstream/handle/10986/16511/NonAs ciiFileName0.pdf? sequence $=1$ \&isAllowed $=y$

Asthana, V. (2012). Forced displacement: A gendered analysis of the Tehri dam project. Economic and Political Weekly, 47, 47-48. Retrieved from http://www.jstor.org/stable/pdf/41720414.pdf?refreqid=excelsior\%3A9e51faf d37ce0998f783a25902698aef

Australian National University. (2012). Laos with province borders and names and provincial capitals. Retrieved from CartoGIS, College of Asia and the Pacific, the Australian National University http://asiapacific.anu.edu.au/mapsonline/base-maps/laos

Berg, B. L., \& Lune, H. (2012). Qualitative research methods for the social sciences (8th ed.). Boston: Pearson.

Bisht, T. C. (2009). Development-induced displacement and women: The case of the Tehri dam, India. The Asia Pacific Journal of Anthropology, 10(4), 301-317. doi:10.1080/14442210903271312

Bui, T. M. H., \& Schreinemachers, P. (2011). Resettling farm households in northwestern Vietnam: Livelihood change and adaptation. International Journal of Water Resources Development, 27(4), 769-785. doi:10.1080/07900627.2011.593116 
Bui, T. M. H., Schreinemachers, P., \& Berger, T. (2013). Hydropower development in Vietnam: Involuntary resettlement and factors enabling rehabilitation. Land Use Policy, 31, 536-544. doi:10.1016/j.landusepol.2012.08.015

Cernea, M. (1997). The risks and reconstruction model for resettling displaced populations. World Development, 25(10), 1569-1587. doi:10.1016/S0305$750 \times(97) 00054-5$

Cernea, M. (2008). Compensation and benefit sharing: Why resettlement policies and practices must be reformed. Water Science and Engineering, 1(1), 89-120. doi: $10.1016 / \mathrm{S} 1674-2370(15) 30021-1$

Cernea, M. M. (2003). For a new economics of resettlement: A sociological critique of the compensation principle. International Social Science Journal, 55(175), 3745. doi:10.1111/1468-2451.5501004

Chacko, E. (2004). Positionality and praxis: Fieldwork experiences in rural India.

Singapore Journal of Tropical Geography, 25(1), 51-63. doi:10.1111/j.01297619.2004.00172.x

Chareun and Associates. (2008). Nam Mang 3 hydropower project assessment report and future management plan for environment and social impacts.

Chidmany, S. (2016). Exploring resettlement impacts of hydroelectric projects: A case study of resettlement due to Nam Theun 2 hydroelectric project in Lao PDR. (Master's thesis), Victoria University of Wellington, Wellington, New Zealand.

Cope, M. (2002). Feminist epistemology in geography. In P. Moss (Ed.), Feminist geography in practice: Research and methods (pp. 43-56). Oxford, UK: Blackwell Publishers.

Creswell, J. W. (2014). Research design: Qualitative, Quantitative, and Mixed Methods Approaches (4th ed.). London, UK: SAGE Publications.

Dalasavong, P., Southiseng, N., \& Walsh, J. (2015). Household production and market engagement among resettled Hmong and Lao Loum communities. Agrarian South: Journal of Political Economy, 4(2), 197-215. doi:10.1177/2277976015593849

Downing, T. E. (2002). Avoiding new poverty: Mining-induced displacement and resettlement. Retrieved from http://pubs.iied.org/G00549/?k=Avoiding+New+Poverty\%3A+Mining$\underline{\text { Induced+Displacement+and+Resettlement }}$ 
Dunn, K. (2005). Interviewing. In I. Hay (Ed.), Qualitative research methods in human geography (pp. 79-105). South Melbourne, Vic: New York: Oxford University Press.

Fane, G. (2006). Trade liberalization, economic reform and poverty reduction in Lao PDR. Journal of the Asia Pacific Economy, 11(2), 213-226. doi:10.1080/13547860600591234

Fernandes, W., \& Paranjpye, V. (1997). Rehabilitation policy and law in India: A right to livelihood. New Delhi: Indian Social Institute.

Flick, U. (2009). An Introduction to qualitative research (4th ed.). London: SAGE Publications.

Fujikura, R., \& Nakayama, M. (2009). Lessons learned from the World Commission on Dams. International Environmental Agreements: Politics, Law and Economics, 9(2), 173-190. doi:10.1007/s10784-009-9093-y

Fujita, Y., \& Phanvilay, K. (2008). Land and forest allocation in Lao People's Democratic Republic: Comparison of case studies from community-based natural resource management research. Society and Natural Resources, 21(2), 120-133. doi:10.1080/08941920701681490

Gallin, R. S., Aronoff, M., \& Ferguson, A. (1991). The Women and International Development Annual. Boulder, CO: Westview Press.

Green, W. N., \& Baird, I. G. (2016). Capitalizing on compensation: Hydropower resettlement and the commodification and decommodification of naturesociety relations in Southern Laos. Annals of the American Association of Geographers, 106(4), 853-873. doi:10.1080/24694452.2016.1146570

GRID. (2006). Lao PDR: Country gender profile. Retrieved from

https://www.jica.go.jp/english/searchResults/index.html?q=Lao\%20PDR\%3A\% 20Country\%20Gender\%20Profile

Guba, E. G., \& Lincoln, Y. S. (1994). Competing paradigms in qualitative research. In N. K. Denzin \& Y. S. Lincoln (Eds.), Handbook of qualitative research (pp. 105-117). Thousand Oaks, California: SAGE Publications.

Hay, I. (2005). Qualitative research methods in human geography (2 ed.). South Melbourne, Vic: New York; Oxford University Press. 
Hull, D. L. (2015). Evolutionary epistemolgy. In J. Wright (Ed.), International encyclopedia of the social \& behavioral sciences (2nd ed., pp. 437-440). Oxford: Elsevier.

Indra, D. M. (1999). Engendering forced migration: Theory and practice. New York and Oxford: Berghahn Books.

Inui, M. (2015). Hmong women and education: Challenges for empowerment in the Lao PDR. Hmong Studies Journal, 16, 1-24. Retrieved from https://search.proquest.com/openview/d721d53bc9cc3e9087a56d4861ba27ba $\angle 1$ ?pq-origsite $=$ gscholar $\& \mathrm{cbl}=28943$

Jackson, C., \& Pearson, R. (2005). Feminist visions of development: Gender analysis and policy. London and New York: Routledge.

Jain, A. (2005). Resettlement in the Narmada Valley: Participation, gender and sustainable livelihoods. (Doctoral dissertation), London School of Economics and Political Science, UK. Retrieved from https://search-proquestcom.helicon.vuw.ac.nz/pqdtglobal/docview/1616978481/A73BE2657252469CP $\mathrm{Q} / 1$ ?accountid $=14782$

Jaquette, J. S., \& Staudt, K. (2006). Women, gender and development. In J. S. Jaquette \& G. Summerfield (Eds.), Women and gender equity in development theory and practice: Institutions, resources and mobilization (pp. 17-52). Durham and London: Duke University Press.

Jing, J. (1997). Rural resettlement: Past lessons for the Three Gorges project. The China Journal, 65-92. doi: 10.2307/2950335

Kabeer, N. (1994). Reversed realities: Gender hierarchies in development thought. London: Verso.

Kaunda, C. S., \& Mtalo, F. (2013). Impacts of environmental degradation and climate change on electricity generation in Malawi. International Journal of Energy \& Environment, 4(3). Retrieved from https://www.ijee.ieefoundation.org/vol4/issue3/IJEE 13 v4n3.pdf

Khouangvichit, D. (2010). Socio-economic transformation and gender relations in Lao PDR. (Doctoral dissertation), Umeå University, Umea, Sweden. Retrieved from https://scholar.google.co.nz/scholar?hl=en\&as sdt=0\%2C5\&q=Socioeconomic+transformation+and+gender+relations+in+Lao+PDR\&btnG $=$ 
Koy, S. (2016). How women's roles in local politics are understood at the commune level: Beoung Preah commune, Cambodia. (Master's thesis), Victoria University of Wellington, Wellington, New Zealand. Retrieved from http://hdl.handle.net/10063/5661

Lahiri-Dutt, K. (2012). Large dams and changes in an agrarian society: Gendering the impacts of Damodar Valley corporation in eastern India. Water Alternatives, 5(2), 529-542. Retrieved from https://search-proquestcom.helicon.vuw.ac.nz/docview/1151964198/fulltextPDF/ADF73FEA8EB4B0DP $\underline{\mathrm{Q} / 1 \text { ?accountid }=14782}$

Lao Statistics Bureau. (2008). Poverty in Lao PDR 2008. Vientiane: Lao Statistics Bureau, Ministry of Planning and Investment. Retrieved from https://www.Isb.gov.la/en/\#.WpSyKKiWbDc.

Lao Statistics Bureau. (2015). Results of population and housing Census 2015. Vientiane: Lao Statistics Bureau, Ministry of Planning and Investment. Retrieved from https://www.Isb.gov.la/pdf/PHC-ENG-FNAL-WEB.pdf.

Lapan, S. D., Quartaroli, M. T., \& Riemer, F. J. (2011). Qualitative research: An introduction to methods and designs. San Francisco, CA: Jossey-Bass.

Liu, S., Lu, P., Liu, D., \& Jin, P. (2007). Pinpointing source of Mekong and measuring its length through analysis of satellite imagery and field investigations. Geo-Spatial Information Science, 10(1), 51-56. doi:10.1007/s11806-007-0011-6

Mack, N., Woodsong, C., MacQueen, K. M., Guest, G., \& Namey, E. (2005). Qualitative research methods: A data collectors field guide. North Carolina: Family Health International.

Matthews, N. (2012). Water grabbing in the Mekong basin - An analysis of the winners and losers of Thailand's hydropower development in Lao PDR. Water Alternatives, 5(2), 392-411. Retrieved from https://search-proquestcom.helicon.vuw.ac.nz/docview/1151964047/993F805E2DB9473CPO/1?accou ntid $=14782$

Maynard, M. (1995). Beyond the 'Big Three': The development of feminist theory into the 1990s. Women's History Review, 4(3), 259-281. doi: 10.1080/09612029500200089

McCully, P. (1996). Silenced rivers: The ecology and politics of large dams. London: Zed Books. 
McDonald, B., Webber, M., \& Yuefang, D. (2008). Involuntary resettlement as an opportunity for development: The case of urban resettlers of the Three Gorges project, China. Journal of Refugee Studies, 21(1), 82-102.

doi:10.1093/jrs/fem052

McDonald, B. D. (2006). From compensation to development: Involuntary resettlement in the People's Republic of China. (Doctoral dissertation), University of Melbourne, Melbourne, Australia. Retrieved from http://hdl.handle.net/11343/39555

Mehta, L., \& Srinivasan, B. (2000). Balancing pains and gains: A perspective paper on gender and large dams. Retrieved from https://www.researchgate.net/profile/Lyla Mehta/publication/301354964 Bal ancing pains and gains A perspective paper on gender and large dams/li $\underline{\text { nks/5714ecde08ae071a51cff83e/Balancing-pains-and-gains-A-perspective- }}$ paper-on-gender-and-large-dams.pdf

Mekong River Commission. (2005). Overview of the hydrology of the Mekong basin. Retrieved from http://www.mekonginfo.org/assets/midocs/0001968-inlandwaters-overview-of-the-hydrology-of-the-mekong-basin.pdf

Middleton, C., Garcia, J., \& Foran, T. (2009). Old and new hydropower players in the Mekong region: Agendas and strategies. In F. Molle, T. Foran, \& M. Kakonen (Eds.), Contested waterscapes in the Mekong region: Hydropower, livelihoods and governance (pp. 23-54). London; Sterling, VA: Earthscan.

Ministry of Energy and Mines. (2016). Map for hydropower development. Retrieved from http://laoenergy.la/download free.php

MPI \& UNDP. (2016). 8th Five-Year National Socio-Economic Development Plan (20162020). Vientiane: Ministry of Planning and Investment. Retrieved from http://www.la.one.un.org/media-center/publications/258-8th-five-yearnational-socio-economic-development-plan-2016-2020.

Murray, W. E., \& Overton, J. (2014). Designing development research. In R. Scheyvens (Ed.), Development fieldwork, a practical guide (2nd ed.). London: SAGE Publications Ltd.

Neuman, W. L. (2012). Basics of social research: Qualitative and quantitative approaches (3rd ed.). Boston: Pearson. 
Parasuraman, S. (1993). Impact of displacement by development projects on women in India. Retrieved from https://ideas.repec.org/p/ems/euriss/18852.html

Patrinos, H. A., Danchev, P. N., Cerdan-Infantes, P., Marshall, J. H., \& Naka, E. (2016). Reducing early grade drop out and low learning achievement in Lao PDR: Root causes and possible interventions. Retrieved from http://documents.worldbank.org/curated/en/161641483590757065/Reducingearly-grade-drop-out-and-low-learning-achievement-in-Lao-PDR-root-causesand-possible-interventions

Peters, H. (1998). Girls' and women's education, policies and implementation mechanisms, case study: Laos. Retrieved from http://unesdoc.unesco.org/images/0011/001146/114673eo.pdf

Phengsavanh, P., Ogle, B., Stür, W., Frankow-Lindberg, B. E., \& Lindberg, J. E. (2010). Feeding and performance of pigs in smallholder production systems in Northern Lao PDR. Tropical Animal Health and Production, 42(8), 1627-1633. doi:10.1007/s11250-010-9612-4

Phimphanthavong, H. (2012). Economic reform and regional development of Laos. Modern Economy, 3(02), 179.

Pholsena, S., \& Phonekeo, D. (2004). Lao hydropower potential and policy in the GMS context. Paper presented at the United Nations Symposium on Hydropower and Sustainable Development, Beijing International Convention Centre.

Phomsoupha, X. (2009). Hydropower development plans and progress in Lao PDR. Hydro Nepal: Journal of Water, Energy and Environment, 4, 15-17. doi:http://dx.doi.org/10.3126/hn.v4i0.1816

Phonepraseuth, V. (2012). From resettlement to sustainable livelihood development:

The potential of resettlement and livelihood restoration arrangement to achieve livelihood sustainability: A case study of resettled communities on the Nakai plateau Nam Theun 2 hydropower project in Lao PDR. (Master's thesis), Massey University, Palmerston North, New Zealand.

Phouxay, K., Malmberg, G., \& Tollefsen, A. (2010). Internal migration and socioeconomic change in Laos. Migration Letters, 7(1), 91-104. Retrieved from https://search-proquestcom.helicon.vuw.ac.nz/docview/847275120?rfr id=info\%3Axri\%2Fsid\%3Aprim $\underline{0}$ 
Rathgeber, E. M. (1990). WID, WAD, GAD: Trends in research and practice. The Journal of Developing Areas, 24(4), 489-502. Retrieved from http://www.jstor.org/stable/4191904

Razavi, S., \& Miller, C. (1995). From WID to GAD: Conceptual shifts in the women and development discourse. Retrieved from http://www.unrisd.org/80256B3C005BCCF9/(httpAuxPages)/D9C3FCA78D3DB3 2E80256B67005B6AB5/\$̧file/opb1.pdf

Rigg, J. (2006). Forests, marketization, livelihoods and the poor in the Lao PDR. Land Degradation \& Development, 17(2), 123-133. doi:10.1002/ldr.719

Sayatham, M. (2013). Livelihoods analysis of affected communities due to Nam Mang 3 hydro power dam. (Unpublished master's thesis), Asian Institute of Technology, Bangkok, Thailand.

Sayatham, M., \& Suhardiman, D. (2015). Hydropower resettlement and livelihood adaptation: The Nam Mang 3 project in Laos. Water Resources and Rural Development, 5, 17-30. doi:10.1016/j.wrr.2015.01.001

Scudder, T. (1993). Development-induced relocation and refugee studies: 37 years of change and continuity among Zambia's Gwembe Tonga. Journal of Refugee Studies, 6(2), 123-152. doi:https://doi.org/10.1093/jrs/6.2.123

Sivongxay, A. (2015). The impacts of hydropower development on livelihoods of downstream communities: Case studies in Laos. (Doctoral dissertation), Charles Darwin University, Australia.

Sivongxay, A., Greiner, R., \& Garnett, S. T. (2017). Livelihood impacts of hydropower projects on downstream communities in central Laos and mitigation measures. Water Resources and Rural Development, 9, 46-55. doi:10.1016/j.wrr.2017.03.001

Smits, M. (2012). The benefits and complexities of distributed generation: Two energy trajectories in Laos and Thailand. Forum for Development Studies, 39(2), 185208. doi:10.1080/08039410.2012.666216

Smits, M., \& Bush, S. R. (2010). A light left in the dark: The practice and politics of picohydropower in the Lao PDR. Energy Policy, 38(1), 116-127. doi:10.1016/j.enpol.2009.08.058 
Soukkaseum, P. (2017). The Relevance of vocational education to the livelihoods of rural Youth, Luang Prabang Province, Laos. (Master's thesis), Victoria University of Wellington, Wellington, New Zealand.

Souksavath, B., \& Maekawa, M. (2012). The livelihood reconstruction of resettlers from the Nam Ngum 1 hydropower project in Laos. International Journal of Water Resources Development, 29(1), 59-70. doi:10.1080/07900627.2012.738592

Standing, H., \& Bandyopadhyaya, B. (1985). Women's employment and the household: Some findings from Calcutta. Economic and Political Weekly, WS23-WS38. Retrieved from http://www.jstor.org/stable/4374339

STEA. (2005a). Decree on the compensation and resettlement of the development project. Vientiane, Laos: Prime Minister's Office.

STEA. (2005b). Regulations for implementing decree No. 192/MP on compensation and resettlement of people affected by development projects. Vientiane, Laos: Prime Minister's Office.

Stür, W., Gray, D., \& Bastin, G. (2002). Review of the livestock sector in the Lao People's Democratic Republic. Retrieved from https://cgspace.cgiar.org/handle/10568/21136

Sukhan, J., \& Adrian, S. (2000). Resettlement for China's Three Gorges dam: Socioeconomic impact and institutional tensions. Communist and Post-Communist Studies, 33(2), 223-241. doi:10.1016/S0967-067X(00)00005-2

Sultana, F. (2007). Reflexivity, positionality and participatory ethics: Negotiating fieldwork dilemmas in international research. $A C M E, 6(3), 374-385$. Retrieved from https://www.acme-journal.org/index.php/acme/article/view/786

Thukral, E. G. (1996). Development, displacement and rehabilitation: Locating gender. Economic and Political Weekly, 1500-1503. Retrieved from http://www.jstor.org.helicon.vuw.ac.nz/stable/pdf/4404272.pdf

Tofail, M. M., \& Kaidab, N. (2015). Evaluating potential benefits of welfare packages for development-induced involuntary resettlement in Bangladesh. Journal of Sustainable Development, 8(1), 203. doi:10.5539/jsd.v8n1p203

Tshering, S., \& Tamang, B. (2004). Hydropower-key to sustainable, socio-economic development of Bhutan. Paper presented at the United Nations Symposium on Hydropower and Sustainable Development. 
UNDP. (2013). MDGs Progress Report for the Lao PDR 2013. Retrieved from http://www.la.undp.org/content/lao pdr/en/home/library/mdg/mdgsprogress-report-lao-pdr-2013.html

UNDP. (2017). The 5th National Human Development Report. Retrieved from http://www.la.undp.org/content/lao pdr/en/home/library/human developme nt/the-5th-national-human-development-report/

Wang, P., Lassoie, J. P., Dong, S., \& Morreale, S. J. (2013). A framework for social impact analysis of large dams: A case study of cascading dams on the UpperMekong River, China. Journal of Environmental Management, 117, 131-140. doi:10.1016/j.jenvman.2012.12.045

Whitworth, S. (1994). Feminist theories: From women to gender and world politics. In P. Beckman (Ed.), Women, Gender, and World Politics (pp. 75-88). London, UK: Bergin \& Garvey.

Wiles, R., Crow, G., Heath, S., \& Charles, V. (2008). The management of confidentiality and anonymity in social research. International Journal of Social Research Methodology, 11(5), 417-428. doi:10.1080/13645570701622231

Willis, K. (2006). Interviewing. In V. Desai \& R. B. Potter (Eds.), Doing development research (pp. 144-152). London: SAGE Publications.

World Bank. (2016). Lao PDR Data. Retrieved from https://data.worldbank.org/country/lao-pdr

World Bank. (2017). The World Bank in Lao PDR. Overview. Retrieved from http://www.worldbank.org/en/country/lao/overview

World Commission on Dams. (2000). Dams and development: A new framework for decision-making: The report of the World Commission on Dams. London; Sterling, VA: Earthscan.

Yong Ooi Lin, C. (2001). Gender impact of resettlement: The case of Babagon dam in Sabah, Malaysia. Gender, Technology and Development, 5(2), 223-244. doi:10.1177/097185240100500203

Young, K. (1997). Gender and Development. In N. Visvanathan, L. Duggan, L. Nisonoff, \& N. Wiegersma (Eds.), The Women, Gender and Development Reader (pp. 5154). London: Zed Books.

Young, K. (2008). WID, GAD, WAD. In V. Desai \& L. Potter (Eds.), The companion to development studies. London: Hodder Education. 
Yüksel, I. (2007). Development of hydropower: A case study in developing countries.

Energy Sources, Part B: Economics, Planning, and Policy, 2(2), 113-121. doi:10.1080/15567240600705201 


\section{Appendices}

\section{Appendix $1.1 \quad$ Human ethics approval}

te Whare wãnanga o te úpoko o te ika a mãu

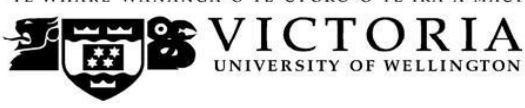

MEMORANDUM

\begin{tabular}{|c|c|}
\hline TO & Singkham Lueyeevang \\
\hline \multicolumn{2}{|c|}{ COPY TO } \\
\hline FROM & AProf Susan Corbett, Convener, Human Ethics Committee \\
\hline DATE & 3 May 2017 \\
\hline PAGES & 1 \\
\hline
\end{tabular}

SUBJECT $\quad$ Ethics Approval: 24488

Gender and resettlement: A case study of the impact of

resettlement on women since the Nam Mang 3 Hydropower dam development in Laos

Thank you for your application for ethical approval, which has now been considered by the Standing Committee of the Human Ethics Committee.

Your application has been approved from the above date and this approval continues until 27 February 2018. If your data collection is not completed by this date you should apply to the Human Ethics Committee for an extension to this approval.

Best wishes with the research.

Kind regards

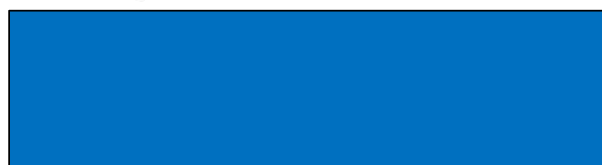

Susan Corbett

Convener, Victoria University Human Ethics Committee 


\section{Appendix 1.2 Human ethics approval}

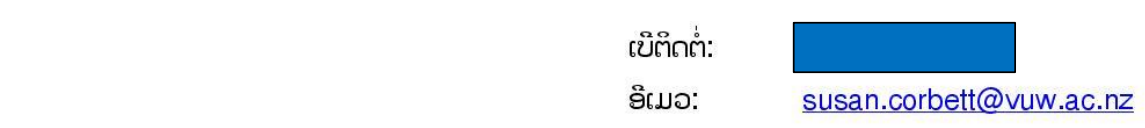

\section{บิกบับซึกภาบยะบุปัก}

\begin{tabular}{|c|c|}
\hline เท๊ง & ข่าบ สิรถำ ล๊ย๊ยาอัว \\
\hline \multicolumn{2}{|c|}{ สำเบิาสิ่าใข้ } \\
\hline จาท & $\begin{array}{l}\text { ธงรสาสะถาจาบ ข่าบ รุ१บ โถเบัด, ปะขาบ, ถะบะรำมะภาบฑั้าจับยา } \\
\text { ขับมะบุถ }\end{array}$ \\
\hline อับขึ & 3 ขึถสะขา 2017 \\
\hline ข้าเจ้ย & 1 (ขึ่ง) \\
\hline ข๊ออ̆ & 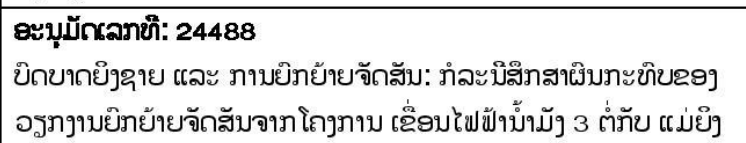 \\
\hline
\end{tabular}

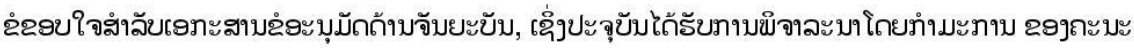
ทำมะภาบถิ้บถ้อาจับยาบัมมะบุถ.

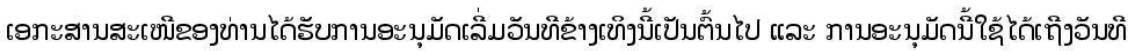

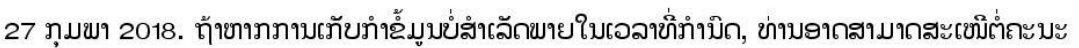
ทำมะภาบเขิ่งฉ์ต่่งายุภาบงะบุมักบิ้.

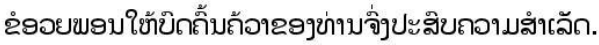

ถ้อยถอบบเถิเลิข

รุขบ โถเขัถ

ปะยาบ, ถะบะภำมะภาบฑั้ภจับยาบับมะบุล มะยาอิขะยาไลอิกชำลย 


\section{Appendix 2.1 Supporting letter (English)}

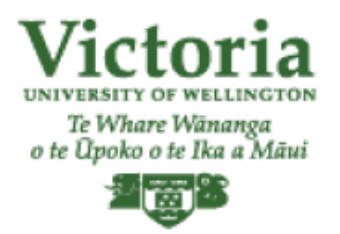

Prof John Overton

Telephone

Email john.overton@vuw.ac.nz

12 May 2017

To Whom It May Concern:

I am writing this letter of support for Singkham Lueyeevang who is undertaking his Master of Development Studies thesis on 'Gender and resettlement: A case study of the impact of resettlement on women since the Nam Mang3 Hydropower dam development in Laos'. I am the supervisor of his thesis and postgraduate studies.

Singkham Lueyeevang is enrolled in a Masters of Development Studies degree at Victoria University of Wellington, Wellington, New Zealand. As a part of his Master's degree programme, he is to undertake field research in Laos for the above thesis from June to August 2017.

The objective of this research is to explore and understand how the lives of women who have been resettled have been impacted by resettlement from hydropower dam development. We feel that this research is both interesting and significant as it hopes to provide a better understanding of issues, challenges and opportunities that helps inform resettlement policy and practice. This research proposal has been approved by the Head of School and obtained ethics approval from the Human Ethics Committee of Victoria University of Wellington.

As I am Singkham's primary supervisor and also Director of the Postgraduate Programme in Development Studies, I fully support Singkham's research project.

If you have any further questions or would like to receive further information about the research project, you can contact me : Prof. John Overton. Phone: $\square$ john.overton@vuw.ac.nz or Singkham. Phone: +8562099861789 or +64220941060 and lueyeesing@myvuw.ac.nz

Yours sincerely,

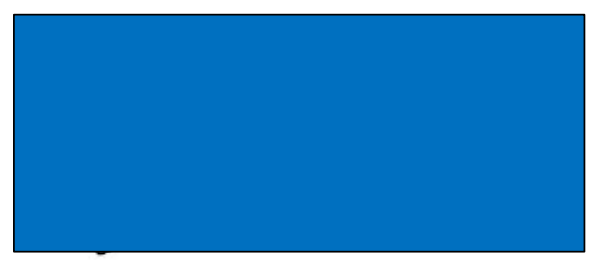

(Prof. John Overton

Director, Postgraduate Programme in Development Studies) 


\section{Appendix 2.2 Supporting letter (Lao)}

\section{Victoria \\ UNIVERSITY OF WELLINGTON \\ Te Whare Wänanga
o te Ulpoko o te Ika a Mäui

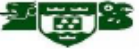

ฮจ. จอบ โดเอิกับ

ใข้ละสับ

QిcدJ: john.overton@vuw.ac.nz

12 ขิถสะขด 2017

ฉ̊ธรมขุาขางสอ่บขิ่กร่อฉ้อง,

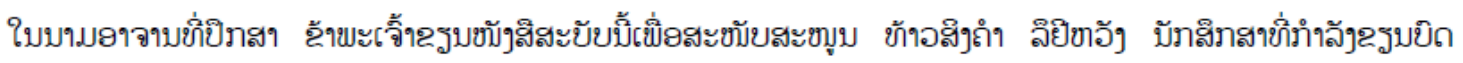

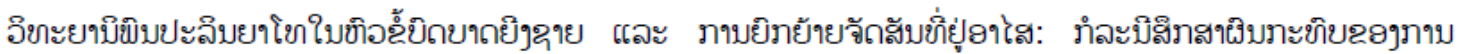

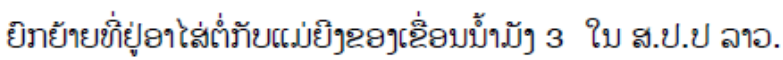

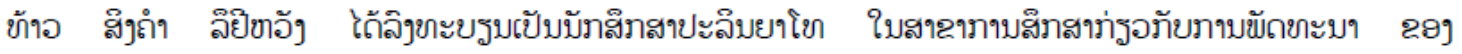

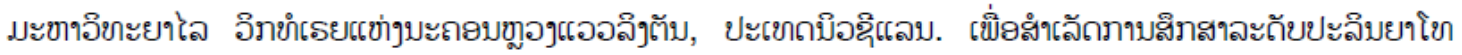

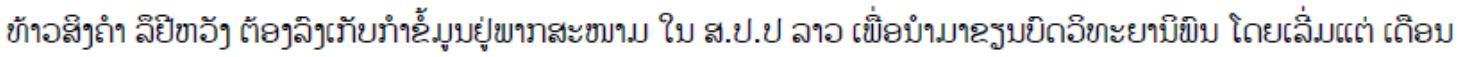
ปิทุบา ขา เถือบสิงขาง ปิ 2017.

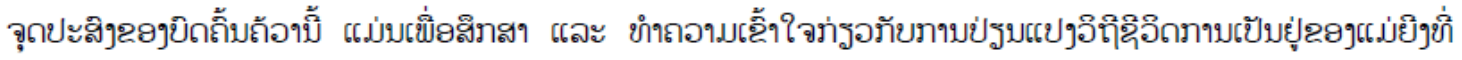

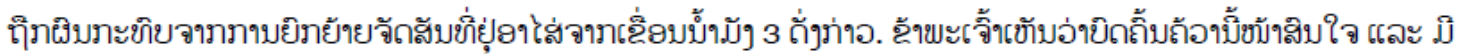

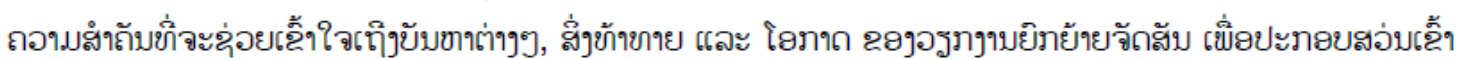

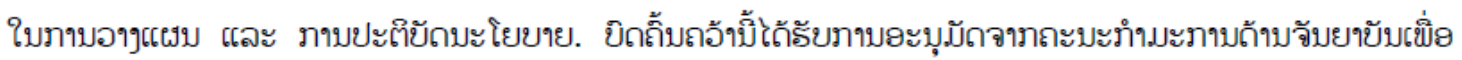

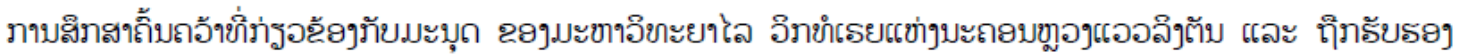
จาภายางข์อยท้าโธรฐรม.

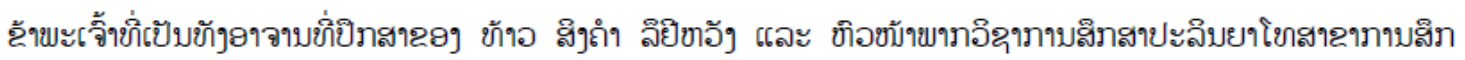
สาภร่อภับภาบขัถขะบา สะขับสะขบูบขิถถิ้มถอ้าฉองผู้งว่อย่างเตัมส่อบ.

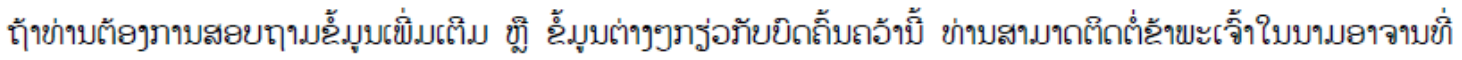

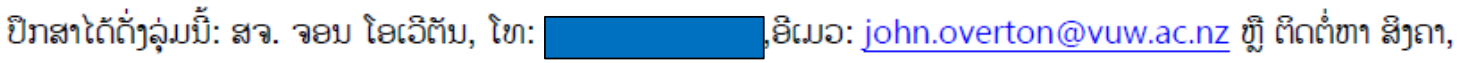

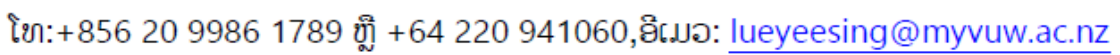

ธรมมาถอ้ยถอามบับทีย่างสูง

สจ. จอบ โดเอิตับ

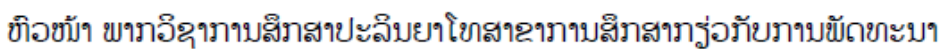




\title{
Appendix 3.1 Information sheet for government office and
}

\section{hydropower project office}

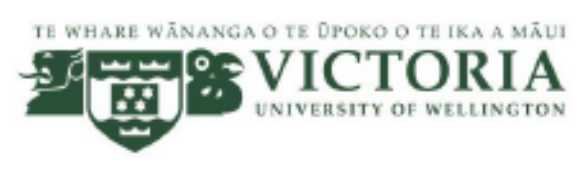

Gender and resettlement: A case study of the impact of resettlement on women since the Nam Mang 3 hydroelectric dam development in Laos

\author{
INFORMATION SHEET FOR PARTICIPANTS \\ (Government officials and Company employees)
}

Thank you for your interest in this project. Please read this information before deciding whether or not to take part. If you decide to participate, thank you. If you decide not to take part, thank you for considering my request.

Who am I?

My name is Singkham Lueyeevang and I am a Master student in Development Studies at Victoria University of Wellington. This research project is work towards my thesis.

What is the aim of the project?

This project aims to explore and understand how women are impacted by resettlement from the Nam Mang 3 hydroelectric dam development project.

This research has been approved by the Victoria University of Wellington Human Ethics Committee [provide approval number].

\section{How can you help?}

If you agree to take part I will interview you at a venue of your choosing. I will ask you about the following topics.

- Role and responsibilities of your organization

- Your personal views regarding hydropower dam development

- Changes that have occurred to the resettled communities since resettlement

- Your views regarding compensation, activities and services provided by the project

- Challenges and opportunities for women in the resettled communities in the future

- Gender policy of your organization

The interview will take about 50 minutes. I will record the interview and write it up later. You can stop the interview at any time, without giving a reason. You can withdraw from the study by contacting me at any point before 27 August 2017. If you withdraw, the information you provided will be destroyed or returned to you.

What will happen to the information you give? 
You will not be named in the final report but your organisation will be named (provided you have the authority to agree to this on behalf of the organisation).

Only my supervisors and I will read the notes or transcript of the interview. The interview transcripts, summaries and any recordings will be kept securely and destroyed 3 years after the research ends.

What will the project produce?

The information from my research will be used in my Masters thesis and also in academic publications and conference presentations

If you accept this invitation, what are your rights as a research participant?

You do not have to accept this invitation if you don't want to. If you do decide to participate, you have the right to:

- choose not to answer any question;

- $\quad$ ask for the recorder to be turned off at any time during the interview;

- $\quad$ withdraw from the study before 27 August 2017;

- ask any questions about the study at any time;

- $\quad$ read over and comment on a written summary of your interview;

- be able to read any summary report of this research by emailing the researcher to request a copy.

If you have any questions or problems, who can you contact?

If you have any questions, either now or in the future, please feel free to contact either:

Student:

Name: Singkham Lueyeevang

University email address:

lueyeesing@myvuw.ac.nz
Supervisor:

\author{
Name: Prof John Overton \\ Role: Director, Postgraduate Program in \\ Development Studies \\ School: School of Geography, Environment \\ and Earth Sciences \\ Phone: \\ Email: John.overton@vuw.ac.nz
}

\section{Human Ethics Committee information}

If you have any concerns about the ethical conduct of the research you may contact the Victoria University HEC Convener: Associate Professor Susan Corbett. Email susan.corbett@vuw.ac.nz or telephone 


\section{Appendix 3.2 Participant consent form for government office and hydropower project office}

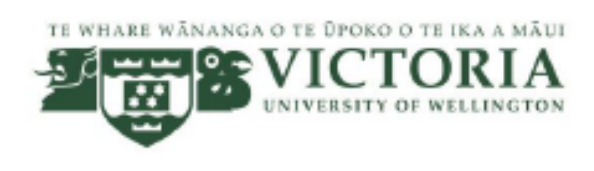

Gender and resettlement: A case study of the impact of resettlement on women since the Nam Mang 3 hydroelectric dam development in central Laos

\section{CONSENT TO INTERVIEW}

(Government officials and Company employees)

This consent form will be held for 3 years.

Researcher: Singkham lueyeevang, School of Geography, Environment and Earth Sciences. Victoria University of Wellington.

- I have read the Information Sheet and the project has been explained to me. My questions have been answered to my satisfaction. I understand that I can ask further questions at any time.

- I agree to take part in an audio recorded interview as outlined in the information sheet.

I understand that:

- I may withdraw from this study at any point before 27 August 2017 , without giving any reason, and any information that I have provided will be returned to me or destroyed.

- The information I have provided will be destroyed 3 years after the research is finished.

- Any information I provide will be kept confidential to the researcher and the supervisor. I understand that the results will be used for a Masters thesis and a summary of the results may be used in academic reports and/or presented at conferences.

- I consent to information or opinions which I have given being attributed to my organisation in any reports on this research:

- I would like a summary of my interview:

Yes $\square \quad$ No

- I would like to receive a summary of the final report and have added my Yes $\square$ No email address below.

Signature of participant:

Name of participant:

Date:

Contact details: 


\section{Appendix 3.3 Information sheet for community}

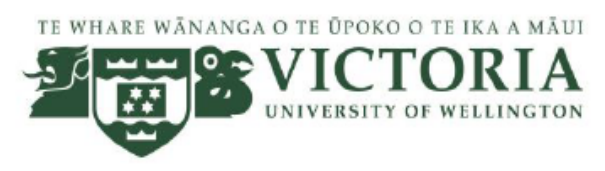

\section{Gender and resettlement: A case study of the impact of resettlement on women since the Nam Mang 3 hydroelectric dam development in Laos

\author{
INFORMATION SHEET FOR PARTICIPANTS \\ (Participants from the communities)
}

Thank you for your interest in this project. Please read this information before deciding whether or not to take part. If you decide to participate, thank you. If you decide not to take part, thank you for considering my request.

\section{Who am I?}

My name is Singkham Lueyeevang and I am a Master student in Development Studies at Victoria University of Wellington. This research project is work towards my thesis.

\section{What is the aim of the project?}

This project aims to explore and understand how women are impacted by resettlement from the Nam Mang 3 hydroelectric dam development project.

This research has been approved by the Victoria University of Wellington Human Ethics Committee [provide approval number].

\section{How can you help?}

If you agree to take part I will interview you at a venue of your choosing. I will ask you the following topics.

- Your livelihood activities before and after resettlement

- Your relations with your community before and after resettlement

- The changes that have occurred since resettlement

- Your access to resources such as land, water, and other natural resources since resettlement

- Your view regarding resettlement, compensation and support from the project

- Your access to facilities and livelihood activities provided by the project

- Your view regarding potential challenges and opportunities you will be facing in the future

The interview will take about 50 minutes. With your permission I will record the interview and write it up later. You can stop the interview at any time, without giving a reason. You can withdraw from the study by contacting me at any point before 27 August 2017. If you withdraw, the information you provided will be destroyed or returned to you. 


\section{What will happen to the information you give?}

This research is confidential. This means that the researchers named below will be aware of your identity but the research data will be aggregated and your identity will not be disclosed in any reports, presentations, or public documentation. However, you should be aware that in small projects your identity might be obvious to others in your community.

Only my supervisors and I will read the notes or transcript of the interview. The interview transcripts, summaries and any recordings will be kept securely and destroyed 3 years after the research ends.

\section{What will the project produce?}

The information from my research will be used in my Masters thesis and it may also be used in academic publications and conference presentations

\section{If you accept this invitation, what are your rights as a research participant?}

You do not have to accept this invitation if you don't want to. If you do decide to participate, you have the right to:

- choose not to answer any question;

- $\quad$ ask for the recorder to be turned off at any time during the interview;

- $\quad$ withdraw from the study before 27 August 2017;

- $\quad$ ask any questions about the study at any time;

- read over and comment on a written summary of your interview;

- be able to read any summary report of this research by emailing the researcher to request a copy.

If you have any questions or problems, who can you contact?

If you have any questions, either now or in the future, please feel free to contact either:

\section{Student:}

Name: Singkham Lueyeevang

University email address:

lueyeesing@myvuw.ac.nz

\section{Supervisor:}

Name: Prof John Overton

Role: Director, Postgraduate Program in Development Studies

School: School of Geography, Environment and Earth Sciences

Phone:

Email: John.overton@vuw.ac.nz

\section{Human Ethics Committee information}

If you have any concerns about the ethical conduct of the research you may contact the Victoria University HEC Convener: Associate Professor Susan Corbett. Email susan.corbett@vuw.ac.nz or telephone 


\section{Appendix 3.4 Participant consent form for community}

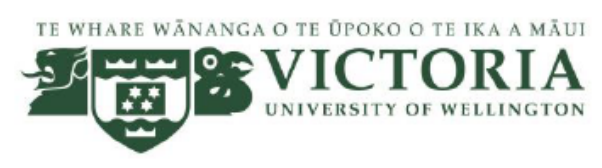

Gender and resettlement: $A$ case study of the impact of resettlement on women since the Nam Mang 3 hydroelectric dam development in central Laos

\section{CONSENT TO INTERVIEW \\ (Participants from the Communities)}

This consent form will be held for 3 years.

Researcher: Singkham lueyeevang, School of Geography, Environment and Earth Sciences. Victoria University of Wellington.

- I have read the Information Sheet and the project has been explained to me. My questions have been answered to my satisfaction. I understand that I can ask further questions at any time.

- I agree to take part in an audio recorded interview as outlined in the information sheet.

I understand that:

- I may withdraw from this study at any point before 27 August 2017, without giving any reason, and any information that I have provided will be returned to me or destroyed.

- $\quad$ The information I have provided will be destroyed 3 years after the research is finished.

- $\quad$ Any information I provide will be kept confidential to the researcher and the supervisor. I understand that the results will be used for a Masters thesis and a summary of the results may be used in academic reports and/or presented at conferences.

- My name will not be used in reports, nor will any information that would identify me.

- I would like a summary of my interview: $\quad$ Yes $\square$ No

- $\quad$ I would like to receive a summary of the final report and have added my Yes $\square$ No email address below.

Signature of participant:

Name of participant:

Date:

Contact details: 


\title{
Appendix 4.1 Interview question guide for government office and hydropower project office
}

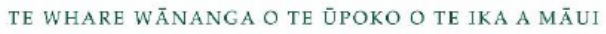

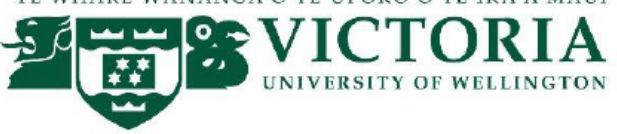

\section{Interview question guides for government and project participants}

(50-60 minutes)

1) What is the role of your organization?

2) What is your view regarding hydropower dam development and resettlement of families?

3) How does resettlement affect women and men?

4) What do you think is the biggest change to gender roles since resettlement of the resettled communities?

5) What do you think are the potential challenges and opportunities for men and women in the future?

6) How did the resettled women participate in the process of resettlement?

7) How do women in the resettled communities access activities and services that are provided by the project?

8) Does your organisation resettlement policy take care of gender issues? 


\title{
Appendix 4.2 Interview question guide for community
}

\author{
TE WHARE WĀNANGA O TE ŪPOKO O TE IKA A MĀUI \\ Sig

\section{Interview question guides for village participants} \\ (50 minutes)
}

Research Title: Gender and resettlement: A case study of the impact of resettlement on women since the Nam Mang 3 hydropower dam

Before asking the following questions, I will introduce myself and ask participants general information such as family members, occupation, how long they have been living in the village, are they resettled by the project or migrate from other places, etc.

1) What are the changes in your role in the home since resettlement?

2) What are the changes in your daily activities inside and outside the home since resettlement?

3) How do you access resources such as land, water, food, and income?

4) How do you access other products that are not grown in your home and community?

5) Are there any resources that were readily available before resettlement and are not limited?

6) How do you feel about their family daily food and income?

7) Who are the potential provider of food and income for your family?

8) How do you spend your time at home compared to the previous village before resettlement?

9) What do you think is your family size since resettlement?

10) How do you provide help for others?

11) How do you make decision on your family spending?

12) How do you and your family access facilities and services that are provided by the project?

13) What are the potential future challenges for you and your family?

14) What are the potential opportunities for you and your family in the future? 


\section{Appendix 5 Request letter to Electric De Lao (EDL)}

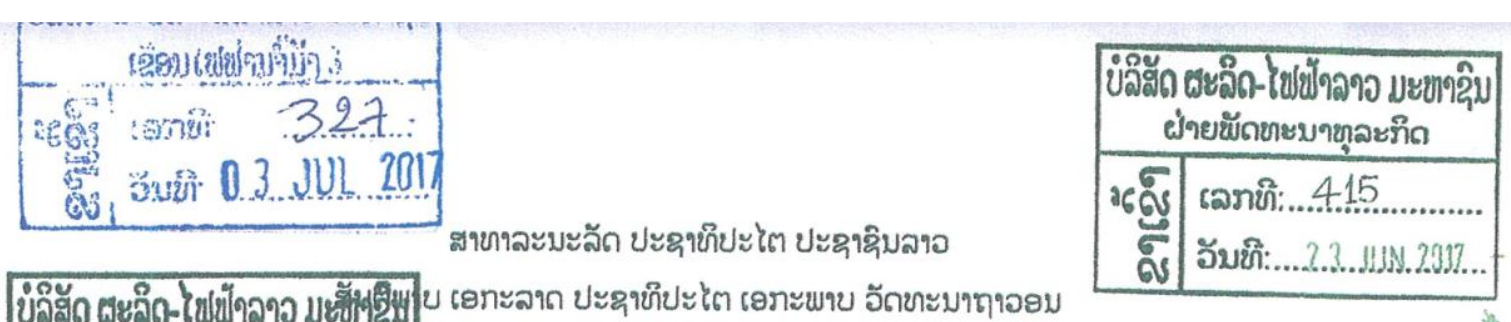

\begin{tabular}{|c|c|}
\hline ข์ลัสัด & 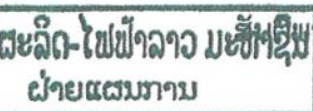 \\
\hline aํ. & 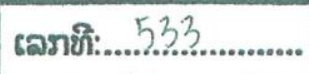 \\
\hline ธ్ & 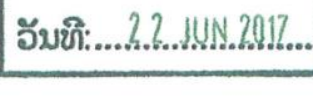 \\
\hline
\end{tabular}

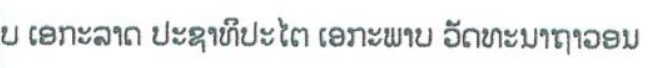

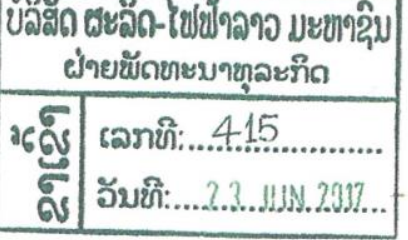

ใบสะเขึ

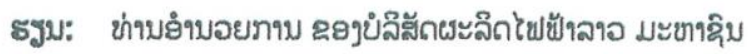

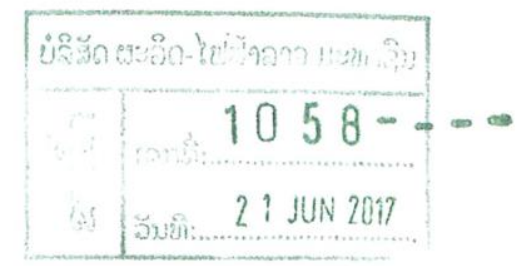

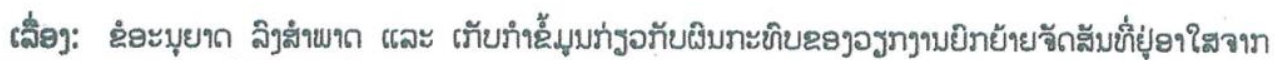

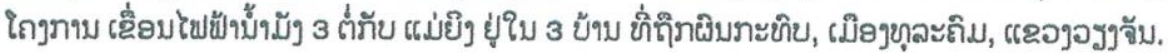

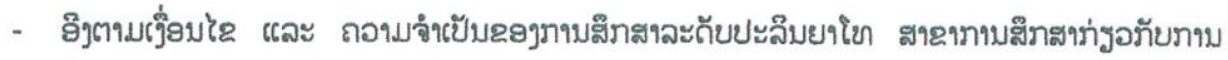

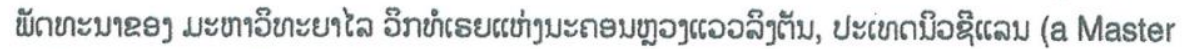
of Development Studies degree at Victoria University in Wellington, New Zealand)

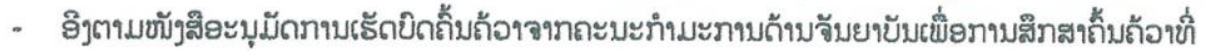

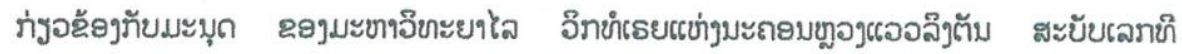
24488, ลิวอับยิ 3 พึกสะพต 2017

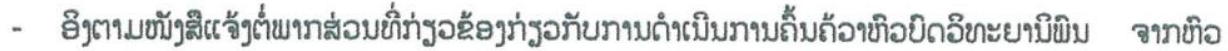

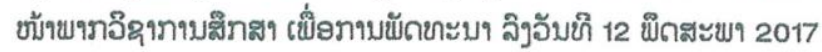

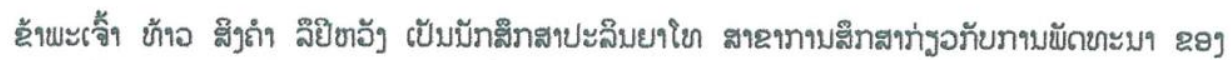

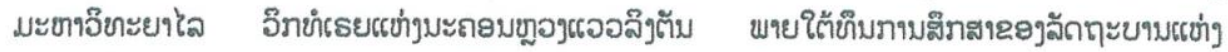

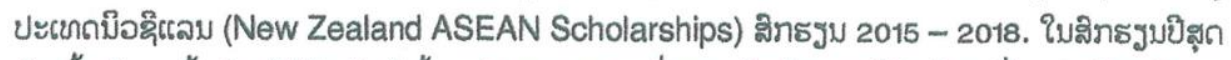

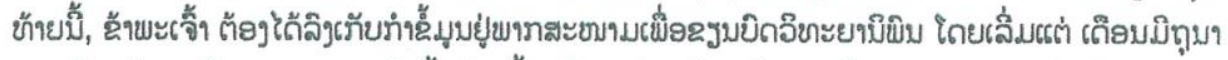

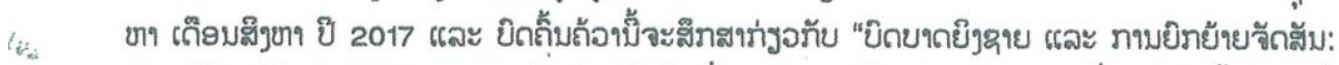

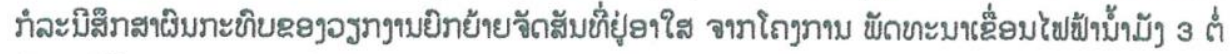
กับ แผ่่ยิต".

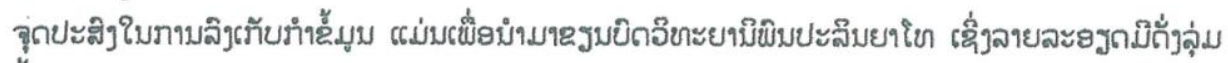
บั้:

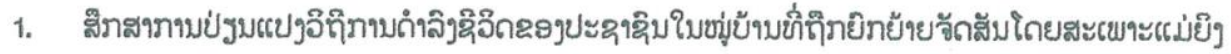
(What have been the changes in women's livelihoods since resettlement?)

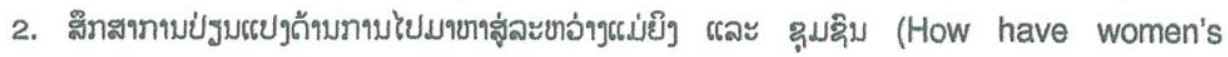
relationships with their community changed since resettlement?)

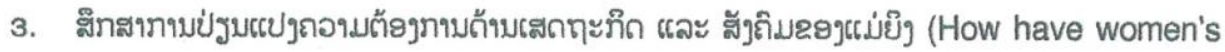
economic and social aspirations changed since resettlement?) 


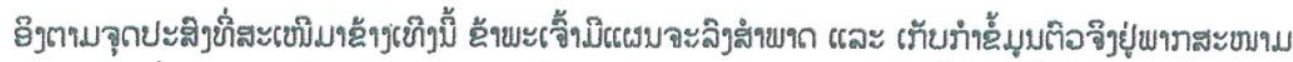

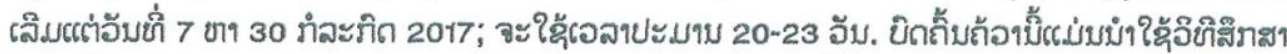

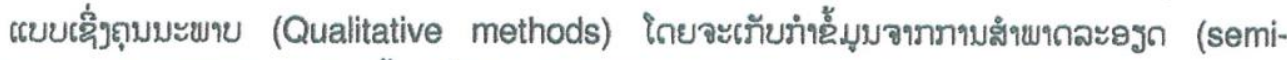
structure interview) และ ฉั้มูมปิฮย (secondary data).

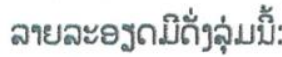

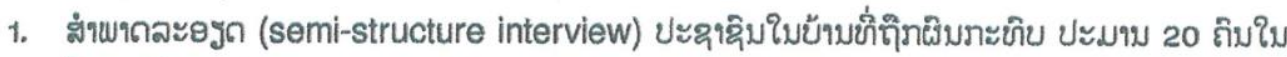

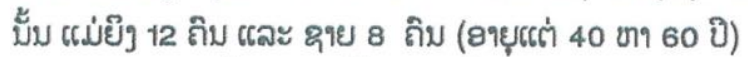

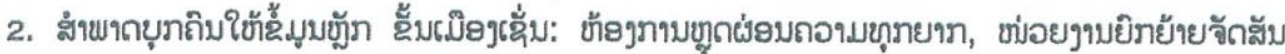

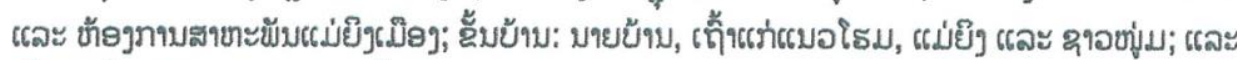

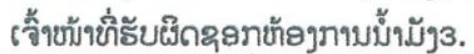

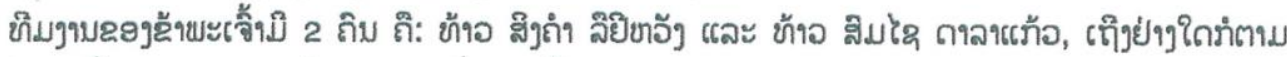

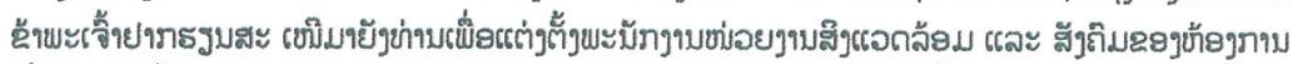

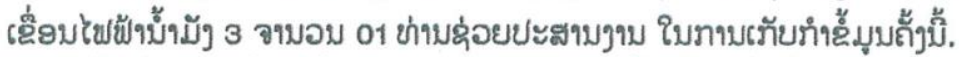

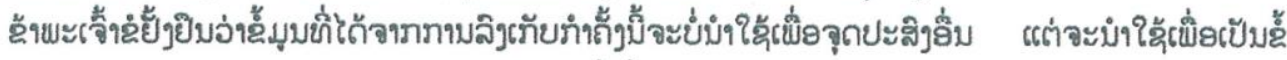

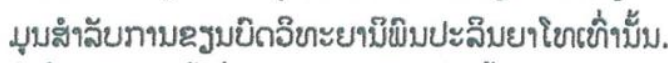

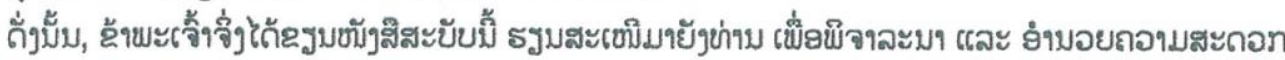

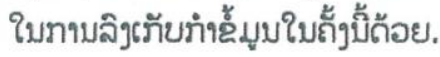

รมมมาก้อยถอบบเถิาลิย ผละ บับท๊ย่างสูง. มะถยมยูอรอราจับ, ส.ป.ป ลาอ 19 .ป็ญุบ 2017

ต้อะมับัก

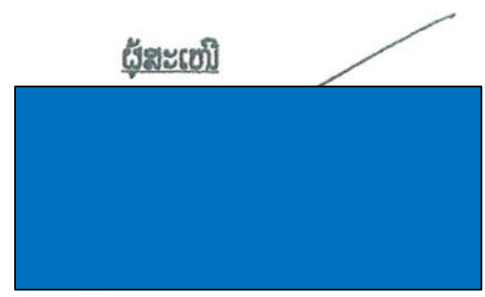

เอกะสามลักสึก:

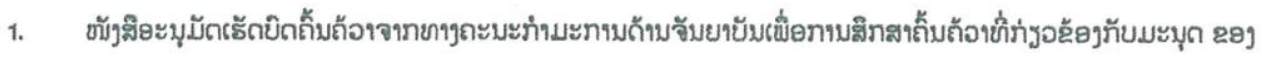

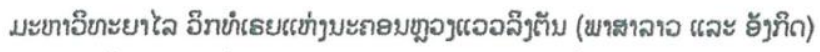

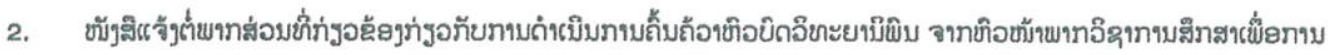
พัดยะบง (พาสหลุอ ผละ ดังภำ)

3. ธ่่งถ์ทุามส่าขาก (แาสาลาอ)

4. ในยั้ไยิบตี่ยุ่

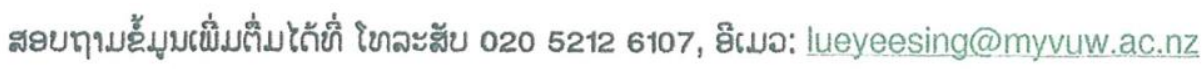




\title{
Appendix 6 Approval letter from Nam Mang 3 hydropower project office
}

\author{
สาขาละมะลัล ปะฉาย๊ปะไต ปะฉาริบลาอ

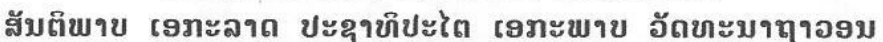 \\ ข้ลีสัถ ผะล็ถ-ไฟข้าลาอ มะยานิิบ \\ ฝายผะล็ถ \\ เลื่อมไขชี่าบ้ำมั 3 \\ เลทชิ 2009 . \\ บ้ำมับ3, ลิดอับขิ................ 2017
}

\section{ใบสะเขึ์}

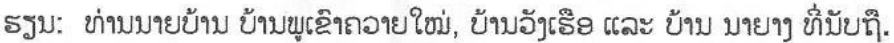

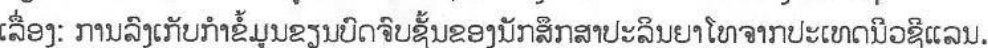

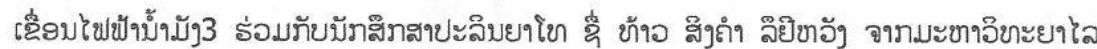

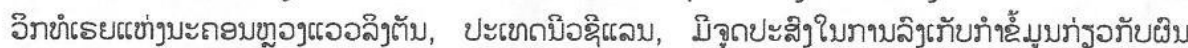

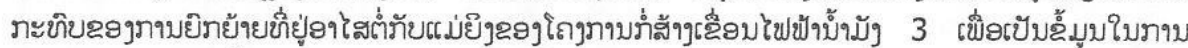
2รบยิกใถราบบจิบฉั้ม.

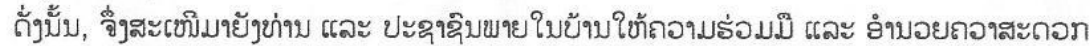

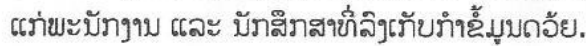

\section{อับขึองกเธักอรภ:}

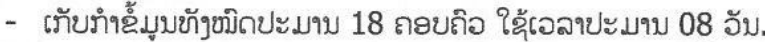

- บ้ามขุเฉิาถอย: 09 ถะบถิอ ใด้เอลๆ 03 อัม เล็มอัมยิ 12-14/07/2017.

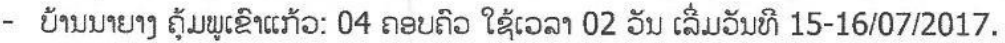

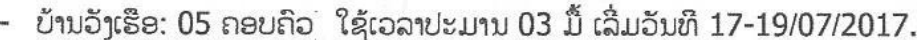

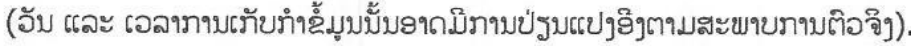

ตู้อำบอยทามเลื่งมไขข้าบ้ำมัด 3

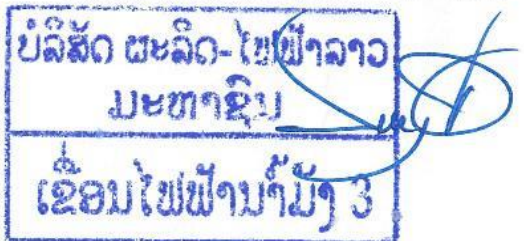

จับถๆ เซยเยย

รยรต้องจบอยภาบ

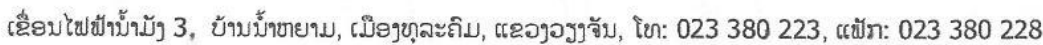




\section{Transcribing Confidentiality Agreement}

Project Title: Gender and resettlement: A case study of the impact of resettlement on women since the Nam Mang 3 hydroelectric dam development in central Laos

Principal Investigator: Singkham Lueyeevang

$\mathrm{I}$, remain confidential to Singkham Lueyeevang and myself.

I agree to take the following precautions:

1. I will ensure that no person, other than the principal investigator, hears the recording.

2. I will ensure that no other person has access to my PC or devices.

3. I will delete the files from my pc or devices once the transcription has been completed.

4. I will not discuss any aspect of the recording with anyone except the principal investigator

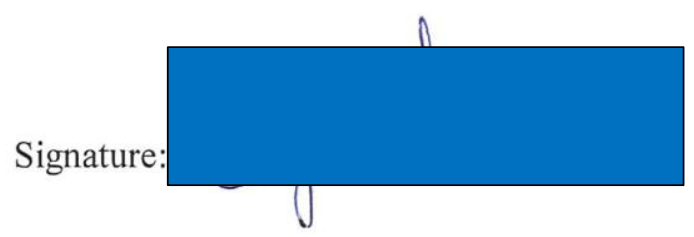

Date: 